UNIVERSIDADE DE SÃO PAULO

FACULDADE DE ECONOMIA, ADMINISTRAÇÃO E CONTABILIDADE DEPARTAMENTO DE ECONOMIA PROGRAMA DE PÓS-GRADUAÇÃo EM ECONOMIA

EFICÁCIA E GESTÃo dA POLÍTICA DE ATENÇÃo BÁSICA DE SAÚDE NOS MUNICIPIOS BRASILEIROS

Sandro Garcia Duarte Peixoto

Orientador: Prof ${ }^{a}$. Dr ${ }^{\text {a }}$. Fabiana Fontes Rocha 
Prof $^{\mathrm{a}}$. Dr ${ }^{\mathrm{a}}$. Suely Vilela

Reitora da Universidade de São Paulo

Prof. Dr. Carlos Roberto Azzoni

Diretor da Faculdade de Economia, Administração e Contabilidade

Prof. Dr. Joaquim José Martins Guilhoto

Chefe do Departamento de Economia

Prof. Dr. Dante Mendes Aldrighi

Coordenador do Programa de Pós-Graduação em Economia 


\section{EFICÁCIA E GESTÃo DA POLÍTICA DE ATENÇÃO BÁSICA DE SAÚDE NOS}

\section{MUNICIPIOS BRASILEIROS}

Dissertação apresentada ao Departamento de Economia da Faculdade de Economia, Administração e Contabilidade da Universidade de São Paulo como requisito para a obtenção de título de Mestre em Economia

Orientador: Prof ${ }^{\mathrm{a}}$. Dr ${ }^{\mathrm{a}}$. Fabiana Fontes Rocha

\section{SÃO PAULO}


FICHA CATALOGRÁFICA

Elaborada pela Seção de Processamento Técnico do SBD/FEA/USP

Peixoto, Sandro Garcia Duarte

Eficácia e gestão da política de atenção básica de saúde nos municípios brasileiros / Sandro Garcia Duarte Peixoto.

- São Paulo, 2008.

$93 \mathrm{p}$.

Dissertação (Mestrado) - Universidade de São Paulo, 2008 Bibliografia

1. Economia da saúde 2. Administração em saúde pública 3. Econometria 4. Saúde da família I. Universidade de São Paulo. Faculdade de Economia, Administração e Contabilidade. II. Título.

CDD - 338.433621 


\section{AgRAdeCimentos}

Agradeço a todos que, de alguma forma, contribuíram para a realização deste trabalho.

Agradeço à Universidade de São Paulo, por me proporcionar um ambiente inspirador com as melhores condições de estudo.

Agradeço aos professores desta casa, que contribuíram muito para enriquecer minha visão de mundo e que me dotaram do ferramental necessário para ser um profissional mais completo. Agradeço à FIPE e ao CNPq pelo apoio financeiro fornecido durante a pós-graduação.

Agradeço à minha orientadora, Prof ${ }^{a}$. Fabiana Rocha, pelas sugestões sempre oportunas e paciência dispensada ao longo da realização desta dissertação.

Aos amigos do IPE, que tornaram a árdua jornada do mestrado bem mais proveitosa e agradável.

Agradeço à minha família, por todo o apoio e carinho. Ao meu pai, por sempre me dar as mãos e me ajudar a chegar até aqui.

À Juliana, por me fazer sempre mais feliz. 


\section{Resumo}

Este trabalho tem como objetivo investigar dois aspectos complementares da política de atenção básica em saúde: auferir sua eficácia, em termos de impacto sobre indicadores de saúde populacionais, e avaliar a qualidade de sua gestão. A referida política se consolidou nos últimos anos como base estruturante do Sistema Único de Saúde. Com execução de responsabilidade dos municípios, sua relevância deriva basicamente de três aspectos, a saber: a política de atenção básica articula um conjunto de atividades voltadas ao cuidado preventivo, o que, em tese, reduz a demanda por serviços terapêuticos; capilariza o sistema de assistência à saúde pelo país; e instrumentaliza a organização dos modelos municipais de saúde.

No que se refere à análise de eficácia, a abordagem empregada foi a econometria de painel de dados, com base na amostra dos municípios da Região Sudeste entre 1999 e 2003. Com base na evolução da cobertura populacional do Programa Saúde da Família e do Programa de Agentes Comunitários de Saúde, constatou-se que a política de atenção básica reduz de forma significativa a mortalidade infantil e a subnotificação de óbitos. Porém, não gera redução das internações hospitalares. Os aspectos concernentes à gestão do programa, por sua vez, foram avaliados com base nos relatórios do programa de fiscalização a partir de sorteios públicos da Controladoria Geral da União. Como principal conclusão derivada de sua análise é que há limitado incentivo para a fiscalização das ações no escopo da atenção básica por parte dos munícipes, uma vez que a política é majoritariamente custeada pela União, ou seja, as populações beneficiárias não internalizam a análise de seu custo-benefício. Além disso, a limitada transparência na condução do programa, fiscalização incipiente e a probabilidade reduzida de punição aos indivíduos envolvidos em irregularidades representam inibidores da disseminação de boas práticas de gestão.

Palavras-chave: Atenção básica, econometria de painel de dados e gestão pública. 


\begin{abstract}
This research investigates two aspects of Brazilian primary health care policy: estimates its impact on municipalities' health indicators and analysis the quality on policy management. Primary health care policy consists in an essential foundation of SUS (health care system), as it embraces a wide range of activities focused on preventive care. Besides that, once municipalities are in charge of providing primary care to inhabitants, the policy contributes to scatter attendance over the country and to organize municipals' health systems.

Our estimates were developed on a panel data approach based on southeastern municipalities' data from 1999 to 2003. The coverage of Programa Saude da Familia (Family Health Program) and Programa de Agentes Comunitarios de Saude (Health Community Agents Program) are used as proxies of primary health care presence on each locality. Our results show the negative impact of primary care both on infant mortality and underreporting of deaths (among the whole population), but they suggest primary care policy did not reduce hospitalization. In what concerns policy management, our analysis was settled on reports developed by the Federal Agency Controladoria Geral da Uniao under its Inspection on States and Municipalities by means of Public Lottery Program. Our main conclusion is that program's design rears low incentives for city citizens to inspect resources expended on primary care. Due to policy funding structure, in which Federal Government finances most of total expenses, local citizens do not internalize its cost-benefit analysis. Besides that, low transparency, inadequate inspection and unlikely punishment for individuals caught committing irregularities inhibit proper management practices adoption.
\end{abstract}

Keywords: Primary health care, panel data econometrics and public management. 



\section{SUMÁRIO}

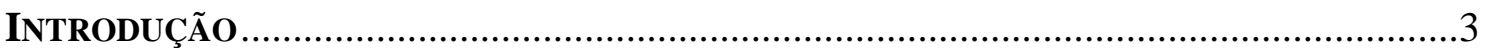

Capítulo I - Panorama da Política de Atenção Básica de Saúde .....................

1.1 Breve histórico do Modelo de Atenção Básica em Saúde no Brasil ........................9

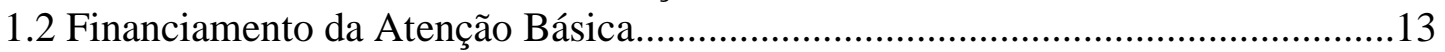

Capítulo II - A Eficácia da Política de Atenção Básica .................................. 18

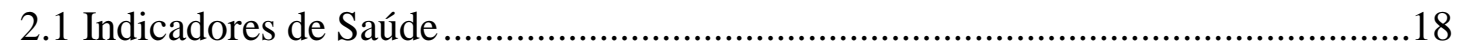

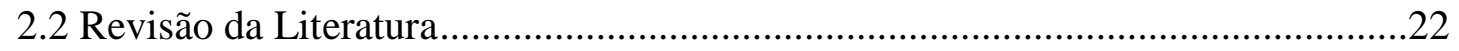

2.3 Eficácia da Atenção Básica - Dados e Metodologia ............................................25

2.4 Eficácia da Atenção Básica - Resultados Econométricos......................................29

CAPÍTULO III - GESTÃo E IRREGULARIDADES NO ÂMBITO DA EXECUÇÃo

Descentralizada da Política de Atenção BÁSICA..................................................39

3.1 Descrição dos Municípios e Relatórios Utilizados................................................41

3.2 Irregularidades no Programa de Saúde da Família.................................................49

3.3 Irregularidades no Programa de Atendimento Assistencial nos Municípios Brasileiros

3.4 Irregularidades no Programa de Estruturação da Rede de Serviços da Atenção Básica

CONCLUSÃO

REFERENCIAS

ANEXO I - DESCRIÇÃO DAS CATEGORIAS DE IRREGULARIDADES RELACIONADAS AOS

Programas da ATENÇÃo BÁSICA de SAÚde............................................................... 71

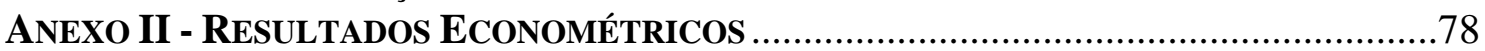




\section{INTRODUÇÃO}

A Constituição Federal de 1988 representou um marco no modelo de atenção à saúde no Brasil. A partir de sua promulgação, todos os cidadãos passaram a ter direito ao acesso a serviços de saúde e, para o cumprimento do disposto, foi criado o Sistema Único de Saúde (SUS). Os artigos da CF dispostos abaixo sintetizam, em linhas gerais, o modelo do sistema de atenção à saúde adotado no Brasil.

Art. 196. A saúde é direito de todos e dever do Estado, garantido mediante políticas sociais e econômicas que visem à redução do risco de doença e de outros agravos e ao acesso universal e igualitário às ações e serviços para sua promoção, proteção e recuperação.

Art. 198. As ações e serviços públicos de saúde integram uma rede regionalizada e hierarquizada e constituem um sistema único, organizado de acordo com as seguintes diretrizes:

I - descentralização, com direção única em cada esfera de governo;

II - atendimento integral, com prioridade para as atividades preventivas, sem prejuízo dos serviços assistenciais;

III - participação da comunidade.

Um dos aspectos mais importantes do SUS consiste na mudança de eixo do modelo de assistência à saúde em favor das ações preventivas, estruturadas a partir da política de atenção básica à saúde, objeto desta dissertação. O trecho transcrito abaixo expressa, sinteticamente, em que consiste a política mencionada.

A Atenção Básica caracteriza-se por um conjunto de ações de saúde, no âmbito individual e coletivo, que abrangem a promoção e a proteção da saúde, a prevenção de agravos, o diagnóstico, o tratamento, a reabilitação e a manutenção da saúde. É desenvolvida por meio do exercício de práticas gerenciais e sanitárias democráticas e participativas, sob forma de trabalho em equipe, dirigidas a populações de territórios bem delimitados, pelas quais assume a responsabilidade sanitária, considerando a dinamicidade existente no território em que vivem essas populações. Utiliza tecnologias de elevada complexidade e baixa densidade, que devem resolver os problemas de saúde de maior freqüência e relevância em seu território. É o contato preferencial dos usuários com os sistemas de saúde. Orienta-se pelos princípios da universalidade, da acessibilidade e da coordenação do cuidado, do vínculo e continuidade, da integralidade, da responsabilização, da humanização, da equidade e da participação social. ${ }^{1}$

A relevância da política de atenção básica não se limita ao fato de esta articular um conjunto de atividades voltadas ao cuidado preventivo e diminuir a ênfase nas práticas terapêuticas. Tal política também assumiu o papel de capilarizar o sistema de assistência à saúde pelo país e de instrumentalizar a organização dos modelos locais de saúde (Viana e Dal

\footnotetext{
${ }^{1}$ Ministério da Saúde, 2006, p. 10.
} 
Poz, 2005). Enquanto porta de entrada de milhões de cidadãos ao SUS, a política de atenção básica consiste no elo entre a população e os serviços de saúde e em ferramenta fundamental no processo de universalização do acesso à saúde. O Programa Saúde da Família (PSF) representa o instrumento ordenador da atenção básica e se estrutura a partir da constituição de equipes multiprofissionais responsáveis por população adstrita territorialmente (Ministério da Saúde, 2001a). Seu objetivo é realizar de forma integral e contínua ações de promoção, proteção e recuperação da saúde dos indivíduos e da família. Ao tornar a família o foco da atenção em saúde, abarcando seu ambiente físico e social, o PSF permite uma compreensão mais ampla do processo saúde-doença do que ocorreria a partir de intervenções pontuais.

Antes, porém, de se apresentar com maior nível de detalhe a política de atenção básica, parece relevante discutir os fundamentos econômicos do modelo do sistema de saúde adotado. Uma pergunta - talvez um pouco provocativa - pode contribuir para motivar essa discussão: ao questionar algum brasileiro, nascido nas três últimas décadas, acerca dos motivos sobre os quais foi deliberado que o Estado é responsável por zelar pela saúde de seus cidadãos, provavelmente, ele responderia que a provisão de serviços de saúde é determinante para a sobrevivência dos indivíduos, e que isto, per se, já justificaria responsabilizar o governo pelo fornecimento de cuidados médicos. Embora o argumento apresentado seja absolutamente legítimo, pode não ser suficiente para explicar a escolha mencionada. Afinal, existe um conjunto considerável de bens indispensáveis à sobrevivência cujo fornecimento, a sociedade brasileira não delegou ao setor público, como, por exemplo, alimentos e habitação. Além disso, foi apenas depois de aprovada a Constituição Federal de 1988 que o Brasil universalizou o acesso ao sistema público de saúde. Ou seja, a prestação gratuita e integral de serviços de saúde não é algo intrínseco à existência do Estado. Ainda assim, verifica-se, em qualquer sociedade civilizada, a presença de algum tipo de intervenção do governo sobre o setor de saúde, ainda que com grande variedade no modus operandi do sistema de assistência à saúde vigente em cada local.

O modelo norte-americano se baseia, predominantemente, na prestação e financiamento privados dos serviços de saúde. O governo federal fornece diretamente seguro de saúde apenas para idosos com idade superior a 65 anos e famílias de baixa renda. Para o restante da população, há um subsídio implícito à adesão na seguridade privada através de desconto no imposto de renda. No Canadá, o financiamento é público e a prestação de serviços privada. Todos os cidadãos são automaticamente segurados, cabendo ao governo o 
pagamento integral a médicos, hospitais e demais prestadores de serviços ${ }^{2}$. O principal ponto em comum é a presença de complexo sistema regulatório.

Duas perguntas emergem a partir dos pontos apresentados: Quais as razões para que seja inevitável a intervenção governamental no setor de saúde? Por que a sociedade brasileira, mediante seus representantes eleitos, decidiu o estabelecimento deste desenho específico para o sistema de saúde?

Para responder a estas perguntas, seria relevante antes discutir os motivos para a existência de governo. A literatura de finanças públicas identifica como três as principais funções do governo: alocativa, distributiva e promoção da estabilidade (Musgrave e Musgrave, 1976). A primeira refere-se à necessidade de o processo político substituir os mecanismos de mercado nas ocasiões em que decisões individuais atomizadas não geram resultados eficientes, o que se aplica a situações em que estão envolvidos externalidades, bens públicos, imperfeições informacionais ou monopólios. A função distributiva constitui-se em distribuir a renda de forma mais condizente com o socialmente desejado, ou seja, tornar mais eqüitativa sua distribuição em relação à que seria produto das forças de mercado isoladamente. A função estabilizadora refere-se ao controle dos agregados macroeconômicos em patamares razoáveis, como taxas de inflação e de desemprego reduzidas.

Com base na teoria do interesse público ${ }^{3}$, a resposta à primeira pergunta está associada às funções alocativa e distributiva desempenhadas pelo setor público. Duas falhas de mercado estão associadas aos bens e serviços de saúde, assim como ao conceito de saúde em si: externalidades e falhas de informação. A questão informacional diz respeito a um conjunto amplo de fatos: bens de saúde exigem a certificação de um especialista para atestar sua eficácia (ou seja, são bens credenciais); existe dissociação entre o consumidor final e o agente responsável pela indicação terapêutica, com o agravante de que o responsável pela indicação da terapia é, geralmente, o mesmo que oferta o bem ou serviço; e problemas de seleção adversa ou risco moral, dado que os indivíduos apresentam propensão a contratar algum seguro de saúde, o que ocorre devido à imprevisibilidade da saúde individual e o alto custo potencial do tratamento (Andrade e Lisboa, 2001a; Rosen, 1995). Os gastos em saúde se caracterizam ainda por apresentarem externalidades positivas, o que justifica $o$

\footnotetext{
${ }^{2}$ Rosen (1995); Santerre e Neun (1996).

${ }^{3}$ A teoria do interesse público assume que os governos têm como objetivo central o bem-estar social e que adotam políticas com base nos critérios da eficiência e equidade.
} 
estabelecimento de algum mecanismo (como subsídios, financiamento público ou produção direta) que induza o consumo privado a aproximar-se do nível social ótimo ${ }^{4}$.

A função distributiva também é justificativa para a intervenção governamental no setor de saúde. A saúde, embora seja um ativo altamente desejado por si só, é pré-requisito para o emprego do fator trabalho em atividades produtivas. E a dotação de fatores, paralelamente à razão de preços entre fatores de produção, é determinante da distribuição de renda. Logo, a garantia de acesso a serviços de saúde à população de baixa renda consiste em elemento de política de equalização de oportunidades.

Embora a decisão sobre a alocação dos recursos orçamentários atenda à lógica de atuação nas áreas em que o mecanismo de mercado não gera resultados eficientes, esta também depende, fundamentalmente, das ideologias e valores compartilhados pela sociedade em um dado momento. O padrão constatado nas sociedades civilizadas é de que os bens de saúde são considerados meritórios ${ }^{5}$ e que deve haver algum tipo de mecanismo que direcione recursos para torná-los mais acessíveis. Até porque, como apresentado no parágrafo anterior,

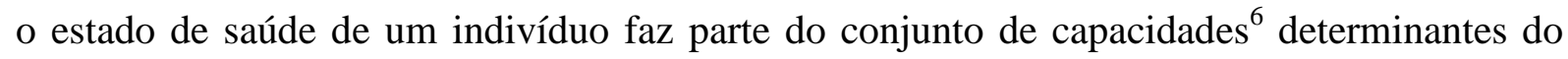
conjunto de escolhas possíveis com o qual ele se depara. Portanto, o acesso à saúde é condição sine qua non para o desenvolvimento econômico e social de determinada sociedade, variando de país para país a forma de enfrentar esta questão. No caso brasileiro, a sociedade julgou que o direito aos serviços de saúde seria inalienável, cabendo ao Estado garantir o acesso a todos os cidadãos. Ou seja, decidiu-se que seriam socializados os custos da provisão da saúde pública. Esta decisão parece expressar a presença de valores peculiares da sociedade brasileira, com um viés mais favorável à presença estatal do que, por exemplo, a norteamericana.

A obrigação acerca da provisão direta de serviços de saúde, naturalmente, não garante que os recursos destinados às ações em saúde sejam devidamente empregados nem que sejam atingidos adequadamente seus objetivos. O interesse, ao longo deste trabalho, é justamente explorar algumas questões associadas a esse ponto, com base em duas análises complementares: avaliar como os recursos destinados à atenção básica são geridos e auferir em que medida a política atinge as metas estabelecidas. Ou seja, o objetivo é avaliar a eficácia

\footnotetext{
${ }^{4} \mathrm{Na}$ presença de externalidades positivas, a quantidade produzida do bem em um mercado puro será inferior ao nível ótimo para a sociedade, já que os indivíduos não internalizam o bem-estar proporcionado aos demais ao consumir os insumos de saúde. Musgrave e Musgrave (1976) classificam os bens que apresentam externalidades positivas como bens mistos.

${ }_{6}^{5}$ Para uma discussão sobre bens meritórios, vide Musgrave e Musgrave, pp.65-66.

${ }^{6}$ Sen, 2000.
} 
e qualidade da gestão da política de atenção básica. Vale destacar que a política de atenção básica, enquanto elo estruturante do modelo assistencial de saúde, é importante receptora de recursos públicos.

Esta dissertação está estruturada de forma a incorporar os aspectos da eficácia e gestão da política de atenção básica. O primeiro capítulo dedica-se à apresentação mais detalhada de que consiste a política de interesse, com apresentação do seu arcabouço institucional, evolução temporal e estrutura de financiamento. $\mathrm{O}$ segundo capítulo expressa a abordagem econométrica, que se destinará à análise da eficácia do programa, que será auferida a partir da estimação do efeito parcial da cobertura populacional da atenção básica (leia-se PSF e PACS) sobre os indicadores de saúde municipais, com base em um painel de dados. O terceiro dedica-se à análise da execução e gestão da política de atenção básica nos municípios. Isso será efetuado com base nos relatórios de fiscalização da Controladoria Geral da União disponibilizados no site do órgão. A partir da sistematização das irregularidades constatadas pelos auditores e apontadas nos referidos relatórios, serão ordenados e analisados os principais desvios cometidos pelos agentes executores, assim como algumas de suas implicações. Desta maneira, torna-se possível detectar as limitações mais importantes com as quais os gestores se deparam, o que pode ser uma informação importante para o desenvolvimento de um quadro institucional mais eficaz e eficiente no que se refere às políticas de atendimento primário. Limitamos a análise aos municípios do sudeste brasileiro, já que é necessário realizar algum recorte para tornar crível a realização deste trabalho e que os dados de saúde referentes a esta região do país tendem a ser mais fidedignos. 


\section{Capítulo I - Panorama da Política de Atenç̃̃o Básica de Saúde}

O desenho atual sistema de saúde brasileiro foi delimitado a partir da Constituição Federal de 1988. A todos os brasileiros, é garantido acesso universal aos serviços de saúde, cabendo à União, Estados e Municípios o cumprimento deste dispositivo constitucional. $\mathrm{O}$ conjunto de ações e serviços de saúde prestados pelo poder público constitui o SUS - Sistema Único de Saúde, norteado com base nas seguintes diretrizes: descentralização políticoadministrativa; atendimento integral, com prioridade a atividades preventivas, sem prejuízo dos serviços assistenciais; e participação social. Neste arcabouço, os municípios tornam-se responsáveis pela execução dos serviços de saúde e ações preventivas ganham destaque na política de saúde pública.

O Ministério da Saúde assume explícita responsabilidade em direcionar esforços na reorientação no modelo de atenção à saúde, com prioridade ao estabelecimento de um sistema voltado à atenção básica. Neste contexto, ao ministério compete $^{7}$ uma série de responsabilidades no sentido de fomentar e articular a execução dos programas voltados à atenção básica, que são executados pelas esferas subnacionais de governo. Dentre as atribuições do ministério, se destacam: o financiamento parcial das ações em saúde; estabelecer diretrizes nacionais; e o fornecimento de assessoria técnica e instrumentos pedagógicos para capacitação dos profissionais.

O Programa Saúde da Família (PSF) consiste em instrumento crucial no processo de reorganização e reestruturação do sistema público de saúde em bases e critérios que transcendem o tradicional enfoque curativo. A Política Nacional de Atenção Básica atribui ao programa o papel de estratégia prioritária na organização de acordo com os preceitos do Sistema Único de Saúde ${ }^{8}$. O PSF se estrutura a partir da constituição de Unidades de Saúde da Família (USF), compostas por equipes multiprofissionais responsáveis por determinada população (Ministério da Saúde, 2001a). Seu objetivo é realizar de forma integral e contínua ações de promoção, proteção e recuperação da saúde dos indivíduos e da família. Ao tornar a família o foco da atenção em saúde, abarcando seu ambiente físico e social, o PSF permite uma compreensão mais ampla do processo saúde-doença do que ocorreria a partir de intervenções pontuais. A composição multidisciplinar das equipes consiste numa das

\footnotetext{
${ }^{7}$ Política Nacional de Atenção Básica, disposta na Portaria 648 / 2006 MS.

${ }^{8}$ Idem.
} 
diretrizes operacionais mais importantes do programa, atendendo ao propósito de ampliar o conhecimento e as possibilidades de intervenção de cada um de seus membros.

Cada equipe de saúde da família trabalha com um território de atuação definido, sendo responsável pelo cadastramento e acompanhamento da população ali residente. A equipe multiprofissional é composta por, no mínimo, um médico generalista ou médico de família, um enfermeiro, um auxiliar ou técnico de enfermagem e agentes comunitários de saúde (Ministério da Saúde, 2006). Ainda existe a possibilidade de inclusão de outros profissionais, dependendo das demandas e possibilidades locais. O Ministério da Saúde recomenda que cada equipe deva ser responsável pelo acompanhamento de, no máximo, 4.000 pessoas, cabendo a cada agente comunitário o acompanhamento, no máximo, de 750 pessoas. Cada USF é responsável pelo primeiro nível de atenção, sendo considerada a porta de entrada no sistema, logo, deve ser dotada de infra-estrutura adequada para realização de consultas, vacinação e demais atividades a serem executadas pelas equipes de saúde de família (EFS). As USFs devem ainda estar integradas a uma rede de serviços dos diversos níveis de complexidade, estabelecendo um sistema de referência que garanta resolutividade e possibilite o acompanhamento dos pacientes (Ministério da Saúde, 2005).

\subsection{Breve histórico do Modelo de Atenção Básica em Saúde no Brasil}

O modelo de atenção básica foi esboçado a partir da promulgação de Constituição Federal de 1988. Entretanto, foi a partir da formação do Programa de Agente Comunitário de Saúde (PACS), em 1991, que se iniciou sua implementação de forma mais efetiva (Viana e Dal Poz, 2005), com o modelo de saúde começando a apresentar contornos mais parecidos com sua configuração atual. $\mathrm{O}$ ministério institucionalizou, naquele momento, experiências com agentes comunitários que ocorriam isoladamente em algumas regiões do país (municípios do Paraná e Mato Grosso e no estado do Ceará). Basicamente, o programa consiste na contratação de agentes comunitários de saúde (ACS), indivíduos escolhidos dentro da própria comunidade a ser atendida, e capacitá-los para o desenvolvimento de atividades de promoção da saúde por meio de ações educativas individuais e coletivas.

O PACS começou a enfocar a família como ação programática de saúde e introduziu a noção de área de cobertura. Neste programa, os ACS são acompanhados e orientados por um enfermeiro de uma unidade de saúde tradicional, executando um amplo conjunto de atividades, dentre as quais se destacam: (a) o cadastramento dos membros de cada família em sua área de atuação, informação esta posteriormente agregada ao Sistema de Informação de Atenção Básica (SIAB) pela Secretaria Municipal de Saúde; (b) realizar visitas domiciliares 
periodicamente, acompanhando as condições de saúde das famílias, com atenção especial para crianças e gestantes; (c) a realização de atividades educativas, no âmbito nutricional, de saúde bucal, na prevenção e combate às endemias, entreoutras; e (d) identificação de áreas e fatores de risco à saúde na comunidade. Desta forma, o agente comunitário constrói um elo entre as comunidades e as unidades de saúde, fazendo com que as unidades básicas de saúde transcendam o papel de receptoras de pacientes (Nogueira et al, 2000; Ministério da Saúde, 2001b).

Inicialmente implantado em regiões mais carentes do Norte e Nordeste, a percepção de que os agentes comunitários poderiam ser peças importantes para organização dos serviços de saúde dos municípios consistiu num estímulo para sua forte expansão e para que o Ministério da Saúde destinasse esforços com objetivo de aperfeiçoá-lo. A experiência acumulada em programas similares, mas geridos por governos locais ${ }^{9}$, tornou clara a vantagem de incorporar novos profissionais à equipe dos $\mathrm{ACS}^{10}$. Neste contexto que, em 1994, foi criado o Programa Saúde da Família, servindo como novo modelo de assistência à saúde e consistindo num instrumento de reorganização do SUS. Inicialmente, a implantação do PSF privilegiava áreas de maior risco social, mas em menos de cinco anos o programa já era encarado como a estratégia estruturante dos sistemas municipais de saúde e da política de atenção básica (Ministério da Saúde, 2005). Desde então, o PACS é compreendido como estratégia transitória para o PSF. Nogueira et al. (2000) afirmam que o Ministério da Saúde tomara a decisão de não contratar agentes comunitários sem vinculação a uma equipe PSF, já à época da realização de seu artigo. Entretanto, tal informação é incongruente com os dados disponibilizados pelo ministério, que adiante serão discutidos. Não obstante, a interface entre os dois programas torna indispensável que consideremos explicitamente o PACS em nossa análise, sobretudo na estratégia de estimação da resposta dos indicadores de saúde e de produção, evitando o viés causado pela omissão de variável relevante.

\footnotetext{
${ }^{9}$ O Programa Médico de Família, implementada pela Prefeitura Municipal de Niterói (RJ) a partir de 1991, consistia na formação de equipes de saúde compostas por um médico generalista e um auxiliar de enfermagem residente na comunidade - responsáveis pelo atendimento de determinada área de abrangência (Terra e Malik, 1998). No PAS (Programa de Agentes de Saúde), gerido pelo Governo do Estado do Ceará, o trabalho do agente era supervisionado por um enfermeiro (Viana e Dal Poz, 2005).

${ }^{10} \mathrm{O}$ experimentalismo bem sucedido que sucedeu a experiência com os agentes comunitários de saúde possui base teórica no chamado "laboratório do federalismo fiscal" (Oates, 1999). Num contexto de informação imperfeita associado a um processo de aprendizado do tipo learning-by-doing, há ganhos potenciais com o estabelecimento de diversos desenhos alternativos para o mesmo programa. $\mathrm{O}$ sistema federativo oferece um arcabouço institucional propício ao estabelecimento destas pequenas variações.
} 
A adesão do município ao PACS e ao PSF exige que o município esteja habilitado em alguma das duas modalidades de gestão ${ }^{11}$ do sistema municipal de saúde, estabelecidas pela Norma Operacional Básica do SUS (NOB-SUS) 01-1996. Com a habilitação, o gestor municipal obriga-se a cumprir os compromissos assumidos perante os demais gestores associados ao SUS e toda a população sob sua responsabilidade. Simultaneamente se torna apto a receber as transferências financeiras previstas para os participantes do sistema de atenção básica, e que adiante serão discutidas em maior detalhe. Dentre os requisitos para habilitação na gestão da saúde básica, destacam-se: garantir o funcionamento dos conselhos municipais de saúde, apresentar o Plano Municipal de Saúde, assegurar atendimento primário em uma unidade básica de referência, a disponibilidade de um profissional de nível superior na supervisão e auxílio às ações de saúde e a existência de fundo municipal de saúde para receber os recursos do programa. (NOB-SUS 01-1996; Viana e Dal Poz, 2005).

O desenho da Política de Atenção Básica, sobretudo no aspecto da descentralização das ações em saúde, encontra fundamento na Teoria de Federalismo Fiscal. A idéia subjacente a este lógica é a de que as esferas municipais e estaduais estão mais próximas da população, então, conseguem captar de forma mais precisa suas preferências e estão sujeita a fiscalização mais próxima dos eleitores (Oates, 1999). O Teorema de Descentralização estabelece que

(...) na ausência de redução de custos mediante a provisão centralizada de determinado bem público (local) e de externalidades interjuridiscionais, o nível de bem-estar será ao menos tão elevado se o fornecimento de bens públicos ocorrer no nível ótimo (de Pareto) para cada uma das localidades, comparativamente ao fornecimento uniforme em todas as jurisdições ${ }^{12}$.

A questão das externalidades interjuridiscionais representa um problema crítico para a provisão descentralizada de diversos serviços de saúde, principalmente o atendimento hospitalar, sobretudo num arcabouço legal como o brasileiro, em que é garantido constitucionalmente o atendimento a qualquer cidadão na rede do SUS. No caso da atenção básica, todavia, o teorema sugere que a provisão descentralizada gera níveis de bem-estar superiores em relação ao fornecimento pela União. Afinal, ao contrário de outras ações de

\footnotetext{
${ }^{11}$ A NOB 01/96 estabelece duas modalidades em que os municípios podem habilitar-se: gestão plena da atenção básica ou gestão plena do sistema municipal. Na primeira, o município assume a responsabilidade sobre ações e serviços de atenção básica à saúde de sua população. Na gestão plena da saúde municipal, além de responsabilizar-se pela provisão da atenção básica, o município assume serviços de maior complexidade, como a gerência de serviços hospitalares e a oferta de procedimentos ambulatoriais de alto custo (Andrade e Lisboa, 2001a).

12 "(...) in the absence of cost-savings from the centralized provision of a [local public] good and of interjurisdictional externalities, the level of welfare will always be at least as high (and typically higher) if Pareto-efficient levels of consumption are provided in each jurisdiction than if any single, uniform level of consumption is maintained across all jurisdictions". Oates, 1972, p. 54 apud Oates, 1999, p. 1122.
} 
saúde, como atendimento ambulatorial e hospitalar, no âmbito do PSF e da atenção básica de saúde, a definição prévia das coberturas territorial e populacional implica em que não haja externalidades interjuridiscionais significativas. Além disso, é intuitivo que a produção das unidades de saúde voltadas ao cuidado preventivo não seja suscetível a retornos crescentes de escala. Ou seja, a descentralização da execução se aplica de forma extremamente adequada no arcabouço da atenção básica.

Existem duas fontes complementares que disponibilizam dados para evolução passada da cobertura do PACS no Brasil: um texto do Ministério da Saúde (2001a) e as informações disponíveis na página do DATASUS. O texto do Ministério dispõe apenas dos dados por região do país, em termos de cobertura populacional e número de agentes contratados, de 1994 a 2001, enquanto no DATASUS há maior nível de desagregação, com informações anuais para cada município do país, a partir de 1998. Pode-se constatar que para aquele período em que há dados disponíveis nas duas fontes, o texto do Ministério exibe, de forma sistemática, valores bem mais elevados ${ }^{13}$ que aqueles fornecidos pela base de dados. Ainda que trabalhemos adiante com os dados do DATASUS, é interessante citar alguns disponibilizados em Ministério da Saúde (2001), de forma a ilustrar a evolução do programa antes de 1998. Em 1994, o PACS ainda se restringia praticamente às regiões Norte e Nordeste, sendo que naquele ano, o programa cobria respectivamente $29 \%$ e $25 \%$ da população daquelas regiões. Não havia, àquela época, agentes comunitários atuando no Sudeste através do programa federal. Apenas em 1997 foram contratados os primeiros agentes comunitários de saúde para trabalhar nesta região. Em 1998, o programa já estava presente em mais da metade dos municípios brasileiros, mas na Região Sudeste, cerca de $40 \%$ dos municípios, eram atendidos. Já a cobertura populacional era de $31 \%$ e $6,5 \%$, respectivamente, no Brasil e no sudeste.

No que se refere à evolução da cobertura do PSF, assim como para o PACS, há dados disponibilizados em um texto do Ministério da Saúde (2001b) e no DATASUS. A disponibilização apresenta o mesmo padrão descrito para o PACS, inclusive com o viés positivo no texto do ministério. Assim como fizemos para o PACS, é ilustrativo dispor alguns dados do texto do ministério para acompanhar a evolução do PSF. Em 1997, o alcance do programa ainda era bastante limitado, com $10 \%$ e $20 \%$ dos municípios assistidos, respectivamente, no Brasil e Sudeste e cobertura populacional de 3,4\% em ambos. Em 1999,

\footnotetext{
${ }^{13}$ A diferença exibida varia de $7 \%$, para a região Sul em 99, a $281 \%$ para o sudeste, em 98 .
} 
o programa estava presente em 34\% dos municípios brasileiros, com cobertura populacional de $10,1 \%$ no país e $7,1 \%$ no Sudeste.

\subsection{Financiamento da Atenção Básica}

O modelo de financiamento adotado para a implantação do sistema de atenção básica tem como objetivo fornecer os incentivos necessários para que os sistemas municipais de atendimento primário se estabeleçam como base estruturante do Sistema Único de Saúde, de acordo com os princípios de universalidade, descentralização e participação social, com o menor custo médio possível. A operacionalização dos serviços fornecidos a partir do Sistema Único de Saúde se baseia em normas estabelecidas pelo Ministério da Saúde, que tratam inclusive do financiamento das ações e serviços de saúde. Até 1996, o mecanismo de financiamento do ministério para os municípios se restringia basicamente à remuneração por produção de serviços. A partir da publicação da NOB/SUS 01/96, norma que regula e instrumentaliza o processo de descentralização do provimento e gestão dos sistemas de saúde, a lógica de financiamento foi alterada, ampliando as transferências de caráter global, com enfoque na cobertura populacional dos serviços prestados. A referida NOB/SUS dispõe que "o financiamento do SUS é de responsabilidade das três esferas de governo e cada uma deve assegurar o aporte regular de recursos, ao respectivo fundo de saúde" ${ }^{14}$. Mas, como descrito na própria norma, o financiamento do SUS na esfera municipal conta com recursos transferidos pela União e Estados, além de recursos oriundos do próprio Tesouro, sendo estabelecidos no corpo da própria NOB os critérios e mecanismos de repasse da União para estados e municípios.

Como já apresentado, uma das condições para implementação do PACS/PSF, e conseqüente recebimento de verbas, é que o município esteja habilitado em uma das modalidades de gestão municipal de saúde. Uma vez habilitado, o Fundo Municipal de Saúde recebe, diretamente do Fundo Nacional de Saúde, os recursos referentes ao Piso da Atenção Básica (PAB). O Piso da Atenção Básica é composto por uma parte fixa, proporcional ao número de habitantes, e pela parte variável, que consiste num incentivo ao estabelecimento de programas especiais, dos quais os mais relevantes são o PSF e PACS. A parte fixa, também conhecida como PAB-Fixo, destina-se ao pagamento das ações previstas no Programa Atendimento Assistencial Básico nos Municípios Brasileiros, que, além de financiar variadas ações de atenção básica (como pagamento de pessoal, aquisição de equipamento, material

\footnotetext{
${ }^{14}$ Norma Operacional Básica do SUS (NOB/SUS) 1996, item 10.1.
} 
para utilização nas Unidades Básicas de Saúde e medicamentos), exige uma série de condicionantes que dotam os municípios de estrutura administrativa para executar as ações em saúde de forma mais eficiente e alinhada com as diretrizes do SUS ${ }^{15}$. Atualmente, o PABFixo remunera cada município anualmente em $\mathrm{R} \$ 13,00$ por habitante.

$\mathrm{O}$ cálculo base para o repasse referente à parte variável do $\mathrm{PAB}$ é de $\mathrm{R} \$ 350,00 / \mathrm{mês}$ para cada agente comunitário de saúde ${ }^{16}$, no caso do PACS. Já para o PSF, em Março de 2006, foi determinada uma alteração no critério de repasses, visando adequar as normas vigentes ao atual momento do desenvolvimento do sistema de saúde no Brasil. Até então, o Ministério da Saúde estabelecia um critério que, conforme pode ser constatado na tabela 1.1, incentivaria a ampliação da cobertura populacional, já que quanto mais elevado o nível de cobertura do programa no município, maior era o repasse efetuado para cada Equipe de Saúde da Família.

\section{Tabela 1.1. Transferências Condicionais ao Programa Saúde da Família (até 2006)}

\begin{tabular}{|c|c|}
\hline $\begin{array}{c}\text { Faixa de cobertura populacional } \\
\text { (em \%) }\end{array}$ & $\begin{array}{c}\text { Valor anual do incentivo por ESF } \\
(\mathbf{R} \mathbf{1 , 0 0})\end{array}$ \\
\hline $0-4,9$ & $28.008,00$ \\
$5-9,9$ & $30.684,00$ \\
$10-19,9$ & $33.360,00$ \\
$20-29,9$ & $38.520,00$ \\
$30-39,9$ & $41.220,00$ \\
$40-49,9$ & $44.100,00$ \\
$50-59,9$ & $47.160,00$ \\
$60-69,9$ & $50.472,00$ \\
$70+$ & $54.000,00$ \\
\hline
\end{tabular}

Fonte: Ministério da Saúde (2001b).

O cálculo da cobertura populacional do PSF, no município i e ano t, era dado pela fórmula $\mathrm{PSF}_{\mathrm{i}, \mathrm{t}}=100 \times\left(\mathrm{ESF}_{\mathrm{i}, \mathrm{t}} \times \mathrm{3}\right.$ 3.450) / população ${ }_{\mathrm{i}, \mathrm{t}}$, onde $\mathrm{ESF}_{\mathrm{i}, \mathrm{t}}$ é o número de equipes de saúde da família atuando no município i e ano t, $\mathrm{PSF}_{\mathrm{i}, \mathrm{t}}$ é o nível de cobertura e população é o número de habitantes segundo a Portaria 5/1999 do IBGE.

A partir de março de 2006, o Ministério da Saúde passou a adotar uma estrutura de financiamento distinta, com duas modalidades de incentivo financeiro (Portaria $n^{\circ}$ 648/GM de 28 de Março de 2006). Na Modalidade I, os municípios recebem R \$ 8.100,00 a cada mês, por equipe, enquanto na Modalidade II, o valor do repasse é de $\mathrm{R} \$ 5.400,00$. Na modalidade I, se

\footnotetext{
${ }^{15}$ Uma descrição mais completa das ações previstas no Programa de Atendimento Assistencial Básico nos Municípios Brasileiros está disposta no capítulo 3.

${ }^{16}$ Segundo disposto no Art. $4^{\circ}$ da Portaria MS 650-2006. Anteriormente à publicação desta portaria, o valor do repasse era de $\mathrm{R} \$ 2.200$ anuais para cada ACS.
} 
enquadram: os municípios com Índice de Desenvolvimento Humano (IDH) igual ou inferior a 0,7 e com população de até 30.000 habitantes (50.000 para os municípios da Amazônia Legal); os municípios integrantes do Programa de Interiorização do Trabalho em Saúde ${ }^{17}$; e as equipes que trabalham em áreas de quilombos ou assentamentos rurais. $\mathrm{Na}$ segunda modalidade, estão incluídos todos os demais municípios brasileiros. A mudança de critério atende às críticas de gestores municipais em grandes centros urbanos, que consideravam que as faixas de incentivo os desfavoreciam, já que a quantidade de ESF deveria ser extremamente elevada para atingir os patamares de cobertura preconizados e receber as maiores faixas de incentivo (Ministério da Saúde, 2005). Além disso, o novo critério incentivaria a convergência dos indicadores de saúde entre os municípios brasileiros, já que os municípios pertencentes à modalidade I seriam caracterizados pela precariedade em seus indicadores e alta incidência de doenças facilmente evitáveis por vacinação, tratamento preventivo, saneamento e doenças materno-infantis.

A política de atenção básica deve também ser financiada pelos governos estaduais e municipais. O desenho de responsabilidade tripartite do SUS tenta conciliar o princípio de heterogeneidade das preferências, o objetivo de redução da assimetria informacional entre os executores das políticas e seus eleitores, as dificuldades e perspectivas geradas pelas externalidades entre municípios e a busca por equidade na geração de serviços públicos entre as regiões. Em relação a este último tema, pode-se argumentar que, caso o financiamento das ações de saúde ficasse a cargo de cada ente federativo, não haveria equalização no acesso aos serviços de saúde entre as populações residentes nas regiões mais pobres e nas mais ricas do país. A homogeneização na prestação de bens públicos consiste numa das funções das transferências intergovernamentais ${ }^{18}$, que representam o principal mecanismo através do qual os agentes executores financiam as ações de saúde no âmbito do Sistema Único de Saúde.

Porém, não há informação sistematizada dos gastos realizados pelos estados e, para os municípios, a informação somente foi disponibilizada para o ano fiscal de 2005 pela Secretaria do Tesouro Nacional. A despeito da escassez de informações acerca do financiamento realizado pelos governos locais, dois estudos trazem alguma luz sobre a

\footnotetext{
${ }^{17}$ O Programa de Interiorização do Trabalho em Saúde tem o objetivo de incentivar a alocação de profissionais de saúde, de nível superior, em municípios de comprovada carência de recursos médico-sanitários.

${ }_{18}$ A literatura atribui três funções principais às transferências governamentais: a internalização pelo ente federativo do benefício gerado pelas atividades localizadas no seu território, cujos efeitos positivos transbordam as fronteiras da sua jurisdição (subsídio pigouviano); os ganhos de eficiência propiciados pela harmonização do sistema tributário nacional; e a geração de equidade no fornecimento de bens públicos entre diferentes regiões do país (Oates, 1999).
} 
questão: um estudo preliminar realizado em 1999 sobre o processo de implantação e funcionamento do PSF, em que foram entrevistados coordenadores estaduais do PSF, secretários municipais de saúde e equipes de saúde de família em 1.219 municípios distribuídos por 24 estados (Ministério da Saúde, 1999); e uma avaliação sobre a implantação do PSF em dez grandes centros urbanos (Ministério da Saúde, 2005).

No trabalho mais recente, foi constatado que há predominância de receitas federais nos gastos com saúde realizados na maioria dos municípios e que, em $60 \%$ dos grandes centros urbanos estudados, as parcelas de recursos próprios gastos em saúde estavam aquém do estipulado constitucionalmente. Já segundo os secretários municipais de saúde entrevistados em 1999, os recursos para pagamento das equipes de saúde de família eram predominantemente do tesouro municipal (em 73,6\% dos municípios) e das transferências do governo federal (em 70,6\%), sendo que apenas 11,6\% dos municípios afirmaram dispor de recursos oriundos dos tesouros estaduais. A comparação dos estudos evidencia a dificuldade de obtenção de dados confiáveis na ausência de contabilidade transparente e harmonizada dos governos locais. $\mathrm{O}$ evidente conflito de interesses dos responsáveis exige cautela na análise desses dados.

Nesse estudo ainda, 37,4\% dos secretários municipais declararam contar com alguma espécie de colaboração do governo do estado no processo de implantação do programa, enquanto 66,5\% manifestaram a existência de apoio estadual para o seu funcionamento. Os valores dispostos logo acima parecem contraditórios em relação àquela informação de que apenas 11,6\% dos municípios recebem recursos do tesouro estadual. Embora o estudo não deixe claro o motivo de tal diferença, deduz-se ser a formulação da pergunta que a produz. De acordo com os coordenadores estaduais entrevistados, em nove estados havia algum tipo de incentivo à implantação ou funcionamento do PSF. Fornecimento de material educativo, cessão ou pagamento de recursos humanos, doação de equipamentos, medicamentos e demais insumos e o repasse de recursos financeiros consistiam nas modalidades de incentivos então existentes. Apenas um estado (Minas Gerais) oferecia contrapartida sistemática para financiamento do programa. Estas informações fornecem algum subsídio para a interpretação da diferença aparentemente contraditória exibida acima: 11,6\% dos municípios brasileiros (ou seja, os municípios mineiros) deviam receber incentivos sistemáticos por parte do respectivo tesouro estadual, enquanto os demais valores se referem à gastos realizados de forma discricionária pelos governadores. A incidência alta de alguma forma de contribuição não sistemática por parte dos governos estaduais poderia estar apontando para a existência de poder discricionário excessivo por parte dos governadores. Além disso, o trabalho realizado 
em 2005 constatou que a participação das secretarias estaduais no financiamento da saúde sob gestão municipal era praticamente nula. 


\section{CAPÍTUlo II - A EFICÁCIA da POLÍtica de AtenĊ̃̃o BáSICA}

O objetivo deste capítulo é explorar a estratégia de atenção básica em saúde, nos municípios da Região Sudeste, com base no instrumental econométrico. A avaliação econômica de intervenções na área da saúde (health care interventions) geralmente mensura os resultados a partir de uma das três perspectivas: monetária, efetividade clínica ou utilidade individual ${ }^{19}$. A indisponibilidade de uma base de dados que discrimine a série histórica dos gastos públicos na atenção básica, por município, impede que a análise seja pela ótica monetária $^{20}$. A ausência de dados também impossibilita que seja seguida a abordagem da ótica da utilidade, já que seria necessário acesso a informações sistematizadas (e ordenáveis) referentes ao bem-estar dos indivíduos atendidos no escopo da atenção básica. Resta-nos, portanto, focar na questão da efetividade clínica, embora façamos uma análise pouco mais abrangente.

A mensuração da eficácia do sistema de saúde de baixa complexidade oferecido pelos municípios do sudeste brasileiro será instrumentalizada a partir da cobertura populacional do Programa Saúde da Família (e do Programa de Agentes Comunitários de Saúde) nos municípios, abordagem desenvolvida inicialmente por Serra (2003). Antes, porém, de apresentar e desenvolver as estratégias de estimação, assim como seus respectivos resultados, convém discutir as formas de mensurar saúde, assim como as perspectivas e principais restrições com as quais os pesquisadores se deparam durante a avaliação de políticas de saúde. O capítulo, portanto, será estruturado da seguinte forma: na primeira seção serão apresentados os diversos indicadores de saúde utilizados nas regressões como variáveis dependentes. $\mathrm{Na}$ seção seguinte, será realizada uma breve revisão da literatura de economia da saúde e da avaliação de programas sociais e de saúde. Na terceira seção é realizada a descrição dos dados empregados neste trabalho. A quarta (e última) seção apresenta as estratégias de estimação acerca da efetividade das ações de atenção básica em saúde em termos dos indicadores de saúde selecionados, assim como seus respectivos resultados.

\subsection{Indicadores de Saúde}

Como já apresentado, estamos interessados em avaliar o impacto da estratégia de atenção básica sobre a saúde da população residente nos municípios do sudeste brasileiro. A

\footnotetext{
${ }^{19}$ Vide McCrone (1998) para uma apresentação organizada de cada uma dessas três perspectivas.

${ }^{20}$ Há informação apenas para o ano de 2005 da série de despesas nos municípios disponibilizadas pela STN, o que não configura um painel de dados.
} 
busca por um indicador que reflita de forma completa as condições de saúde de determinada população, no entanto, não é tarefa trivial, afinal, as limitações existentes na conceituação de saúde ou doença se refletem na mensuração dos eventos relacionados a estes dois conceitos (Barreto e Carmo, 2000). De acordo com Fournier (1997), as seguintes propriedades devem ser apresentadas por um indicador de saúde: validade, confiabilidade, sensibilidade, especificidade e inteligibilidade. $\mathrm{O}$ critério da validade se refere à habilidade de o indicador oferecer a diversidade de valores necessários na avaliação do estado e desenvolvimento do fenômeno estudado. Confiabilidade diz respeito à capacidade do indicador em fornecer números estáveis em diferentes períodos e localidades. Sensibilidade seria a habilidade de um indicador em reagir, sobretudo a variações no curto prazo, a mudanças no fenômeno representado. Especificidade traduz-se como a característica de um indicador em variar somente devido a alterações afetando o fenômeno sob observação ou devido a intervenções e, por último, mas não menos importante, a inteligibilidade diz respeito à capacidade de compreensão do indicador por parte de não especialistas.

No que se refere à aferição da qualidade de um sistema de saúde a partir de dados relacionados ao estado de saúde da população atendida, tanto o aspecto da morbidade ${ }^{21}$ quanto da mortalidade devem ser considerados. A utilização dos dados de mortalidade como instrumento de avaliação de um sistema de saúde é, certamente, de grande valia, tanto para se aferir a capacidade de prevenção deste sistema, como sua capacidade de intervenção curativa. A objetividade inquestionável do evento morte e a obrigatoriedade de sua vinculação ao Código Internacional de Doenças, além de sua comunicação compulsória minoram substancialmente problemas como subnotificação e imprecisão dos dados.

A taxa de mortalidade infantil é o mais tradicional e utilizado dos indicadores de saúde. Ela representa o risco de um nascido vivo em determinada localidade falecer durante seu primeiro ano de vida (Laurenti et al., 1987). Uma vez que crianças de até um ano de idade são extremamente vulneráveis às condições sócio-ambientais em que estão inseridas, a taxa de mortalidade infantil é muitas vezes utilizada como proxy para as condições gerais de vida de determinada sociedade. Logo, consiste num indicador que reflete, em linhas gerais, as condições de saúde populacionais. Quando analisados de forma mais precisa as causas de óbitos infantis vis-à-vis o período em que ocorreram, constata-se que as causas diferem substancialmente entre recém-nascidos e os demais. Os óbitos de crianças recém-nascidas geralmente ocorrem devido a problemas congênitos, complicações do parto e nascimento

\footnotetext{
${ }^{21}$ A morbidade se refere ao estado de saúde dos indivíduos vivos.
} 
prematuro, enquanto em crianças com mais de um mês de vida doenças diarréicas e infecciosas são os principais vilões (Grossman \& Jacobowitz, 1981; Serra, 2003). Em função desta nuance, é comum a decomposição da mortalidade infantil em dois componentes: o neonatal e o pós-neonatal. A taxa de mortalidade neonatal representa a quantidade de óbitos ocorridos entre o $1^{\circ}$ e o $28^{\circ}$ dia de vida, por mil nascidos vivos, enquanto a taxa pós-neonatal corresponde às mortes ocorridas do $29^{\circ}$ ao $364^{\circ}$ dia. Em sociedades mais desenvolvidas, com presença de taxas reduzidas de mortalidade infantil, há predomínio do componente neonatal, enquanto em populações mais carentes há tendência de que a morte pós-neonatal seja dominante. Isto pode ser explicado pelo fato de que as causas mais frequentemente responsáveis pelos óbitos pós-neonatais são facilmente evitáveis por vacinação, cuidado preventivo ou medidas de saneamento ambiental.

A mortalidade infantil, entretanto, não expressa completamente todos os aspectos referentes ao nível de saúde populacional, já que foca num substrato bastante restrito da população e que isso pode acarretar em que não capte fenômenos não associados a crianças com até um ano de idade como, por exemplo, a evolução de doenças crônico-degenerativas. Além disso, sua tendência declinante, em períodos recentes e em várias sociedades, poderia fragilizar seu papel como principal indicador, já que careceria da mencionada sensibilidade por Fourier.

De forma a fornecer mais robustez à análise desenvolvida, o presente trabalho avaliará o impacto parcial do PSF sobre outros indicadores que expressem a qualidade do sistema de saúde com a qual determinada população se depara: o índice de anos de vida perdidos e o quantum de internações hospitalares de residentes. Esta escolha tem como sustentação a argumentação apresentada por Marinho e Façanha (2001) acerca da avaliação de programas sociais em que afirmam que "a forma genérica com que são formulados programas sociais de governo e a multiplicidade de objetivos envolvidos criam obstáculos críticos para avaliações de eficácia" ${ }^{22}$. A avaliação da eficácia, portanto, requer o estabelecimento de indicadores que expressem de forma fidedigna os objetivos do programa em questão, sendo que a utilização de mais de um indicador deve atender ao critério de captar a pluralidade de metas da política em questão.

Com a abordagem a partir da construção do índice de anos potenciais de vida perdidos (IAVP), espera-se poder avaliar se há impactos diferenciados do programa em diferentes segmentos etários da população. O índice foi uma técnica desenvolvida por Romeder e

\footnotetext{
${ }^{22}$ Marinho e Façanha, 2001, p. 7.
} 
McWhinnie (1977) com a finalidade de ordenar as principais causas responsáveis por mortes prematuras. Embora seja mais comum sua utilização para determinar a importância de mortes prematuras provocadas por uma causa específica, o índice de anos potenciais de vida perdidos consiste num indicador para o peso das mortes prematuras frente a estrutura de mortalidade de determinada comunidade. Do ponto de vista da análise do bem estar, o cálculo dos anos de vida perdidos parece adequado, uma vez que considera a estrutura etária associada à mortalidade em cada país (Andrade e Lisboa, 2001b). Para aplicação no Brasil, o cálculo utiliza dados censitários sobre população e registros civis sobre óbitos. Seguiremos neste trabalho a abordagem utilizada por Romeder e McWhinnie, que considera todos os óbitos entre 1 e 70 anos de idade, assumindo que esta última idade corresponde à expectativa de vida da população, para ambos os sexos. Uma crítica eventualmente efetuada a este indicador, seria que este daria excessiva importância a mortes ocorridas em jovens, resulta num "viés" que favorece intervenções afetando pessoas mais jovens. Entretanto, como já comentado, justamente por atribuir maior peso a óbitos de indivíduos mais jovens que parece mais apropriado por uma perspectiva do bem-estar. Uma forma de atenuar um pouco a crítica mencionada seria atribuir um desconto tal que desse maior importância aos anos a serem vividos no futuro próximo, em detrimento dos anos a serem vividos num futuro mais remoto ${ }^{23}$ (Fournier, 1997).

Uma avaliação baseada apenas na mortalidade, no entanto, restringe-se à situação limite da efetividade de um sistema de saúde, enquanto que uma aferição que abarcasse também os dados de morbidade poderia revelar aspectos mais qualitativos, além de ter estreita ligação com a capacidade produtiva do indivíduo. O conceito contemporâneo de saúde incorpora a qualidade de vida, mesmo sabendo do elevado grau de subjetividade associado a este conceito $^{24}$. Embora haja indisponibilidade de dados, no Brasil, acerca da percepção dos indivíduos sobre sua qualidade de vida, a utilização de informações associadas a internações hospitalares consiste numa alternativa que viabiliza a incorporação da morbidade à análise, dispensando a realização de um recorte focado somente na mortalidade. A utilização de informações referentes a internações hospitalares é relevante na medida em que se pode auferir em que medida as ações preventivas executadas no escopo da atenção básica

\footnotetext{
${ }^{23}$ Não há qualquer alteração substantiva nos resultados encontrados quando incluída a taxa de desconto (entre $1 \%$ e $3 \%$ ao ano) no cálculo do índice de anos de vida potencialmente perdidos.

${ }^{24}$ Nos países desenvolvidos, a morbidade é avaliada com base em índices de anos de vida ajustado à qualidade de vida (QALY). Infelizmente, no Brasil, não há dados e pesquisas que permitam a construção do QALY. (Andrade e Lisboa, 2001b).
} 
conseguem reduzir a incidência de enfermidades mais graves e, consequentemente, a utilização de serviços hospitalares.

Naturalmente, críticos mais severos podem vir a questionar o conjunto de indicadores escolhido, defendendo que haveria alguma variável mais representativa dos padrões de saúde populacionais como, por exemplo, a mortalidade materna ${ }^{25}$. Entretanto, é importante ressaltar que a escolha de indicadores teve como critério abarcar tanto o maior espectro populacional possível em termos de faixa etária - e, nesse sentido, o índice de anos de vida perdido consiste em complemento para a mortalidade infantil - quanto aspectos relacionados pela morbidade, captados, ainda que parcialmente, pelas informações referentes às internações. No caso específico da mortalidade materna, chegou-se a realizar as estimações, mas os resultados foram totalmente inconclusivos, com todos os coeficientes estatisticamente iguais a zero ${ }^{26}$, provavelmente devido à pouca confiabilidade das informações referentes a esta variável dispostas no DATASUS.

\subsection{Revisão da Literatura}

Esta parte será dedicada a comentários acerca de algumas experiências apresentadas na literatura acerca de avaliações de programas sociais com fundamento teórico em economia da saúde.

Gertler (2000) apresenta uma avaliação do PROGRESA - programa de combate à pobreza extrema estabelecido em 1997 no México - sob a perspectiva dos indicadores de saúde infantil. O PROGRESA consiste num programa tradicional de transferência de renda, mas cujo desembolso exigia a contrapartida de que os beneficiários participassem de uma série de atividades voltadas ao desenvolvimento de capital humano, como cuidado médico preventivo, programas nutricionais e educacionais. Uma das especificidades mais interessantes do programa reside em que sua avaliação já foi concebida como sua parte integrante desde o estágio inicial. Isto porque a maior dificuldade associada à avaliação de programas, de forma geral, consiste no fato de que os participantes não podem ser observados

\footnotetext{
${ }^{25}$ A mortalidade materna é definida como a morte de mulheres durante a gravidez ou até 42 dias após o parto, causada ou agravada direta ou indiretamente pela gravidez (WHO, 2004). Dada a impossibilidade de se determinar com precisão o número de gestações, a mortalidade materna é medida em relação ao numero de nascidos vivos. Ela reflete, basicamente, as condições de assistência pré-natal e ao parto, assim como aspectos biológicos da reprodução humana e a presença de doenças provocadas ou agravadas pela gravidez e parto (Fonseca e Laurenti, 2000). Embora se espere que uma política com forte ênfase no atendimento integral e ação preventiva, como a estratégia de atenção básica e o PSF, deva exibir impacto significativo sobre a mortalidade materna, a pouca confiabilidade dos dados no Brasil, devido à subestimação em relação aos óbitos maternos de fato ocorridos, impede que esta sirva de indicador adequado.

${ }^{26}$ Não houve alteração nos resultados quando excluídos da amostra os municípios com população pequena.
} 
no estado alternativo de não participação do programa. Ou seja, quando a adesão dos indivíduos é voluntária, o pesquisador não consegue afirmar categoricamente se a resposta dos participantes à variável de interesse pode ser atribuída ao programa per se ou a existência de um viés de seleção ${ }^{27}$. O viés de seleção significa a presença de algum atributo não observado que motiva os indivíduos a participarem no programa que os torna diferentes das demais pessoas.

Para superar este problema, a partir do universo de 50.000 localidades elegíveis ao PROGRESA, 506 foram aleatoriamente escolhidas como grupo de tratamento e de controle. As características sócio-econômicas antes da introdução do programa eram bastante similares entre os dois grupos. No grupo de tratamento, as famílias elegíveis receberam os benefícios imediatamente, enquanto no grupo de controle, apenas em dois anos seriam iniciadas as transferências (sem que as famílias soubessem que iriam receber benefícios no futuro). As famílias participantes do experimento foram acompanhadas durante dois anos, de forma que pudesse ser avaliada a evolução das suas características. A partir da estimação por diferenças em diferenças, Gertler concluiu que o PROGRESA conseguiu atingir os objetivos propostos: houve melhora estatisticamente significante da saúde dos beneficiários, com incidência menor de doenças no grupo de tratamento que no grupo de controle; no grupo de tratamento houve participação superior nos programas nutricionais; a utilização das clínicas foi superior por parte dos beneficiários, enquanto sua utilização dos hospitais foi inferior, indicando a diminuição de doenças mais graves.

Infelizmente para economistas e pesquisadores em geral, via de regra, os programas não são desenhados já concebendo a avaliação como sua parte integrante, requerendo algum tratamento especial para sua avaliação, tal como a estimação mediante um painel de dados, abordagem adotada neste trabalho.

Um outro fato merecedor de destaque na literatura de economia da saúde foi o declínio, de 4,4\% ao ano, da taxa de mortalidade infantil nos Estados Unidos entre 1964 e 1977. Ao longo deste período, haviam sido introduzidas quatro políticas públicas de saúde que eram identificadas como potenciais responsáveis pela redução acelerada da mortalidade infantil: Medicaid ${ }^{28}$; projetos de cuidado materno-infantil; serviços subsidiados de planejamento familiar para famílias de baixa renda e a legalização do aborto. Grossman \& Jacobowitz (1981) investigaram a contribuição relativa de cada política sobre o componente

\footnotetext{
${ }^{27}$ Wooldridge, 2002.

${ }^{28}$ Programa federal para fornecimento de seguro-saúde para famílias de baixa renda.
} 
neonatal da mortalidade infantil, com base num modelo multivariado. A abordagem empregada consistiu na estimação por mínimos quadrados ordinários da contribuição relativa da variação entre 1964-1977 das variáveis explicativas sobre a tendência observada do componente neonatal, num contexto de cross-section. A conclusão mais marcante é que o crescimento de abortos legais foi o fator mais importante na redução da taxa de mortalidade neonatal, dominando inclusive escolaridade e pobreza.

Como comentado na introdução do capítulo, o Programa Saúde da Família também já foi objeto de estudo, a partir da estimação de um painel de municípios paulistas com dados referentes ao período entre 1998 e 2001, com o objetivo de auferir o impacto parcial da cobertura do programa sobre a mortalidade infantil. Serra (2003) pressupõe um modelo teórico que incorpora os determinantes mais importantes da probabilidade de sobrevivência dos menores de um ano (e de seu complemento imediato, a taxa de mortalidade infantil), que pode ser explicitado a partir de uma função de produção de saúde infantil no seguinte formato:

$$
\text { tmi }=f(i, p s f, p a c s, r, x, e)
$$

A variável dependente - taxa de mortalidade infantil - é uma função estocástica de um vetor de insumos médicos $i$, da presença e do grau de cobertura do PSF e do PACS no município, da renda per capita $r$, de um vetor de variáveis exógenas de risco para a saúde infantil $x$, medidas localmente, e da dotação de saúde materno-infantil $e$.

A inclusão do vetor representando a renda per capita municipal como variável de controle segue a tradição dos trabalhos em economia da saúde e em saúde pública (Becker \& Lewis, 1973; Prichett \& Summers, 1996). Afinal, depende da restrição orçamentária da família o acesso a níveis nutricionais adequados, habitação salubre, água tratada, medicamentos e demais insumos médicos cuja oferta seja realizada por agentes privados. A não inclusão da renda per capita poderia tornar inconsistentes os coeficientes estimados, pois estaríamos incorrendo na omissão de variável potencialmente relevante. Uma questão relevante a ser atentada se refere à potencial endogeneidade devido a determinação simultânea de renda e saúde. Existem três explicações plausíveis para a relação positiva entre renda e saúde: (i) renda mais elevada torna os indivíduos mais saudáveis; (ii) trabalhadores saudáveis são mais produtivos, logo, recebem salários mais elevados (causalidade reversa); (iii) algum outro fator pode contribuir tanto para que os indivíduos se tornem simultaneamente mais ricos e saudáveis (correlação espúria). A partir de estimação por variáveis instrumentais, utilizando a mortalidade infantil como proxy para os níveis de saúde populacionais, Prichett \& Summers (1996) concluíram que a relação positiva entre renda e saúde é causal e estrutural, partindo 
unilateralmente da renda para a mortalidade. Com base neste resultado, sustentamos a manutenção da renda per capita na estimação.

A representação do vetor de insumos médicos incorpora algumas variáveis representativas da disponibilidade de serviços de saúde à população de interesse, além do PACS/PSF, como a disponibilidade de hospitais (leitos hospitalares), número de médicos e total de despesas municipais em saúde e saneamento. As variáveis de risco à saúde infantil expressam elementos que exercem influência potencial sobre a saúde da criança, como aspectos ambientais e a proporção de gravidezes de risco. Uma vez que não há informação acerca destas variáveis, Serra utiliza a proporção de mulheres com menos de 15 anos ou mais de 44 anos em relação à população feminina total em idade fértil, além de informações referentes à escolaridade como proxies para as variáveis de risco à saúde infantil. As taxas de distorção idade-conclusão do ensino médio e fundamental foram incorporadas como proxy para o grau de escolaridade das mulheres no município. Elas representam o percentual de mulheres que concluem, respectivamente, o ensino médio e fundamental com idade superior à recomendada pelo Ministério da Educação.

Serra conclui que os mencionados programas apresentam efeito (matematicamente) negativo sobre a mortalidade infantil. As elasticidades calculadas pela especificação escolhida indicam que aumentos de $100 \%$ na cobertura do PACS e do PSF resultam em redução de respectivamente $0,6 \%$ e $0,7 \%$ na taxa de mortalidade infantil do município, além de que os coeficientes associados ao PSF e ao PACS indicam, respectivamente, redução de quatro e de dez óbitos infantis por mil nascidos vivos como resposta à cobertura de $100 \%$ da atenção básica comparativamente ao estado inicial de ausência de atendimento primário.

\subsection{Eficácia da Atenção Básica - Dados e Metodologia}

Seguindo a estratégia de estimação proposta em Serra (2003), neste trabalho o efeito parcial da atenção básica será estimado com base num painel de municípios em que as coberturas populacionais do PACS e PSF são utilizadas como variáveis explicativas de interesse. A utilização de um painel apresenta a vantagem de possibilitar o controle da heterogeneidade não observada, ou seja, de efeitos específicos associados a determinado município ou ano. Desta forma, é possível superar um potencial viés provocado pela omissão de variáveis, desde que a variável relevante não observada pelo pesquisador seja constante no tempo, pois a variável omitida será captada pelo efeito específico associado a cada município (Wooldridge, 2002). O modelo a ser estimado será um painel básico com efeitos não observáveis do tipo: 


$$
i s_{i t}=\beta X_{i t}+f_{i}+\delta_{t}+\varepsilon_{i t}
$$

$\mathrm{O}$ indicador de saúde de cada município $i$ e ano $t$ é representado por is $\mathrm{i}_{\mathrm{it}}$; $\mathrm{X}_{\mathrm{it}}$ constitui a matriz de variáveis explicativas para cada município $i$ e ano $t ; \mathrm{f}_{\mathrm{i}}$ consiste no efeito específico do município $i$, ou seja, aquelas características do município invariantes no tempo e não observadas pelo pesquisador; $\delta_{\mathrm{t}}$ representa a dummy referente ao ano $\mathrm{t}$; e $\varepsilon_{\text {it }}$ consiste no distúrbio idiossincrático referente ao município $i$ no ano $t$.

Sob a hipótese (que assumimos) de exogeneidade estrita, ou seja, de que toda a informação relevante está contida na variável explicativa contemporânea à dependente, empregamos três metodologias de estimação: pooled ordinary least squares (POLS), efeitos aleatórios (RE) e efeitos fixos (FE). O mais apropriado deles depende das hipóteses realizadas subjacentes ao modelo de interesse.

Embora dentre os métodos citados, POLS seja o menos restritivo ${ }^{29}$, este apresenta uma séria deficiência que é não considerar explicitamente os efeitos específicos associados a cada unidade de observação, fazendo com que estes sejam incorporados ao termo de erro $\left(u_{i}=f_{i}+\right.$ $\left.\varepsilon_{i t}\right)$. Isto implica em que os estimadores de POLS serão consistentes apenas se não houver correlação entre os efeitos específicos do município e as variáveis explicativas observadas, o que na prática é excessivamente restritivo de ser assumido. Ainda assim, POLS apenas poderá será eficiente se o efeito específico de cada município for estatisticamente igual a zero.

A estimação por efeitos aleatórios considera explicitamente o termo específico $\left(f_{\mathrm{i}}\right)$ e gera estimadores mais eficientes que POLS na presença de efeitos não observados relevantes, embora imponha uma estrutura mais rígida ${ }^{30}$. O teste Breusch-Pagan fornece uma estatística que indica a existência do efeito específico não observado, indicando qual dos métodos fornece estimadores mais eficientes. Porém, uma condição de consistência da estimação por efeitos aleatórios é o termo específico ser não correlacionado com as variáveis explicativas observadas.

Na maioria das aplicações, a grande vantagem de se dispor de um painel de dados é justamente admitir a existência de correlação arbitrária entre $\mathrm{x}_{\mathrm{it}} \mathrm{e}$ o efeito específico. Como discutido, os estimadores POLS e de efeitos aleatórios não são consistentes caso esta

\footnotetext{
${ }^{29}$, A consistência de POLS depende de que sejam atendidas as seguintes hipóteses:

(a) $\mathrm{E}\left(\mathrm{X}_{\mathrm{i}} \mathrm{u}_{\mathrm{i}}\right)=0, t=1,2, \ldots, \mathrm{T}$; $\mathrm{e}$

(b) $\mathrm{E}\left(\mathrm{X}_{\mathrm{i}}{ }^{\prime} \mathrm{X}_{\mathrm{i}}\right)$ tenha posto pleno (a condição de posto pleno é comum aos três métodos citados).

${ }^{30}$ A eficiência de efeitos aleatórios neste caso é propiciada pelo fato de a estimação ser num contexto de mínimos quadrados generalizados. A estrutura necessária para a consistência de RE é a existência de exogeneidade estrita do erro idiossincrático em relação ao vetor de observáveis $\mathbf{x}_{\mathrm{it}}$ e ao efeito específico, assim como a ortogonalidade entre efeitos específicos e demais variáveis explicativas observadas.
} 
correlação se verifique. Os estimadores de efeitos fixos contornam esta restrição, sendo considerados mais robustos ${ }^{31}$. Um teste de Hausman pode ser aplicado para fins de comparação dos estimadores de efeitos fixos e de efeitos aleatórios, ou seja, se há presença de autocorrelação entre $f_{i}$ e $\mathbf{x}_{i t}$. Caso sejam atendidas suas hipóteses subjacentes, o estimador de efeitos fixos é o mais eficiente na classe de estimadores que pressupõem exogeneidade estrita (Wooldridge, 2002).

Não obstante a semelhança metodológica, diversas modificações foram introduzidas em relação à pesquisa de Serra (2003), algumas das quais já discutidas: a área de abrangência da pesquisa, o período de referência, os indicadores de saúde e as variáveis de controle. O painel abarca todos os municípios da Região Sudeste no período entre 1999 e 2003. Este período foi adotado em função de as séries anuais de leitos hospitalares e obstetrícios por município - uma importante variável de controle representativa dos insumos médicos disponíveis à população de interesse - serem interrompidas no ano de 2003.

As variáveis de controle utilizadas consistem naquelas que refletem a qualidade do sistema de saúde e/ou as condições sócio-ambientais dos residentes nos municípios e são variantes no tempo. Sua inclusão nas regressões é necessária em função de o modelo teórico utilizado considerá-las relevantes para a determinação das variáveis dependentes (os indicadores de saúde). É importante incluir as variáveis de controle na regressão porque estamos interessados em estimar o efeito parcial das variáveis da cobertura do PSF e PACS sobre os indicadores de saúde, mantendo fixas as demais variáveis relevantes. Ou seja, a matriz de variáveis explicativas $\mathrm{X}_{\mathrm{it}}$ é composta pelos vetores das variáveis de interesse (PACS e PSF) e pelos vetores das variáveis de controle ${ }^{32}$. As variáveis de controle, representativas da renda per capita municipal, do vetor de insumos médicos e de variáveis de risco à saúde utilizadas nas estimações, estão dispostas na tabela 2.1.

Nas estimações priorizamos a utilização de taxas e coeficientes (per capita, por cem, mil ou cem mil habitantes) em detrimento dos valores absolutos das variáveis explicativas, já que estas apresentariam substancial multicolinearidade entre si e em relação à população residente em cada município. Ou seja, sua inclusão como variáveis explicativas isoladas

\footnotetext{
${ }^{31} \mathrm{O}$ estimador de efeitos fixos mantém a hipótese de exogeneidade estrita $\mathrm{E}\left(\varepsilon_{\mathrm{it}} \mid \mathrm{x}_{\mathrm{i}}, \mathrm{f}_{\mathrm{i}}\right)=0, t=1,2, \ldots, \mathrm{T}$ e impõe a seguinte estrutura para a inferência estatística: os erros idiossincráticos $\mathrm{u}_{\mathrm{it}}$ são homocedásticos e apresentam correlação serial nula.

${ }^{32}$ Formalizando, estamos interessados em estimar $\mathrm{E}(\mathrm{y} \mid \mathrm{w}, \mathrm{c})$, em que a vetor $\mathbf{y}$ representa a variável dependente (o indicador de saúde), w seria uma matriz 2 x NT cujas colunas representam as variáveis de interesse, respectivamente a cobertura populacional respectivamente do PSF e do PACS e c consiste na matriz de variáveis de controle de dimensão (K-2) x NT. Alternativamente, w pode consistir num vetor de dimensão NT cujas colunas representam a soma da cobertura do PSF e do PACS.
} 
provocaria elevação dos erros padrão associados aos coeficientes estimados, o que significa obtermos estimativas menos precisas.

Tabela 2.1. Descrição das variáveis de controle

\begin{tabular}{|c|c|c|}
\hline Nome & "Descrição da variável & Fonte \\
\hline PIBPC & Produto Interno Bruto municipal, por habitante & IBGE \\
\hline HOSP & $\begin{array}{l}\text { Total de leitos hospitalares municipais cadastrados no } \\
\text { SUS, excluindo os leitos de UTI (coeficiente por mil } \\
\text { habitantes) }\end{array}$ & DATASUS \\
\hline OBST & $\begin{array}{l}\text { Leitos de clínica obstétrica municipais cadastrados no } \\
\text { SUS (coeficiente por mil habitantes) }\end{array}$ & DATASUS \\
\hline ODIPC & $\begin{array}{l}\text { Óbitos causados por doenças infecciosas } \mathrm{e} \\
\text { parasitárias (coeficiente por cem mil habitantes) }\end{array}$ & DATASUS \\
\hline IDIPC & $\begin{array}{l}\text { Internações provocadas por doenças infecciosas e } \\
\text { parasitárias (coeficiente por cem mil habitantes) }\end{array}$ & DATASUS \\
\hline RGEST & $\begin{array}{l}\text { Gestações de risco: proporção de mulheres que possui } \\
\text { menos de } 15 \text { anos ou mais de } 44 \text { anos, em relação ao } \\
\text { total de mulheres em idade fértil ( } 10 \text { a } 49 \text { anos) }\end{array}$ & DATASUS \\
\hline DICEMM & $\begin{array}{l}\text { Taxa de distorção idade-conclusão do ensino médio - } \\
\text { Sexo Feminino }\end{array}$ & INEP-MEC \\
\hline DICEMG & $\begin{array}{l}\text { Taxa de distorção idade-conclusão do ensino médio - } \\
\text { Ambos os sexos }\end{array}$ & INEP-MEC \\
\hline DICEFM & $\begin{array}{l}\text { Taxa de distorção idade-conclusão do ensino } \\
\text { fundamental - Sexo Feminino }\end{array}$ & INEP-MEC \\
\hline DICEFG & $\begin{array}{l}\text { Taxa de distorção idade-conclusão do ensino } \\
\text { fundamental - Ambos os sexos }\end{array}$ & INEP-MEC \\
\hline DES_EF & $\begin{array}{l}\text { \% de docentes com ensino superior nas escolas de } \\
\text { nível fundamental }\end{array}$ & INEP-MEC \\
\hline DES_EM & $\begin{array}{l}\text { \% de docentes com ensino superior nas escolas de } \\
\text { nível fundamental }\end{array}$ & INEP-MEC \\
\hline EVAS_EM & Taxa de abandono - Ensino Médio & INEP-MEC \\
\hline EVAS_EF & Taxa de abandono - Ensino Fundamental & INEP-MEC \\
\hline
\end{tabular}

Em relação à origem dos dados, as coberturas populacionais do PACS e do PSF são obtidas no DATASUS, base de dados disponibilizada pelo Ministério da Saúde. A população residente em cada município $i$ e ano $t$ é estimada pelo IBGE, com base na evolução da população municipal constatada a partir dos censos. A renda per capita municipal também é calculada anualmente pelo IBGE. Os totais de leitos hospitalares e obstetrícios cadastrados no SUS, disponibilizados pelo DATASUS, consistem nos vetores de insumos médicos acessíveis aos residentes ${ }^{33}$. As séries de leitos representaram os limitadores para o período do painel,

\footnotetext{
${ }^{33}$ Algumas variáveis utilizadas por Serra (2003) não foram aqui empregadas, como coeficiente de médicos por mil habitantes, taxa de urbanização municipal e despesas municipais anuais por função de saúde e saneamento. Tal fato ocorreu, em primeiro lugar, porque a Fundação SEADE é o único órgão que disponibiliza dados anuais referentes ao coeficiente de médicos por mil habitantes e à taxa de urbanização municipal, o que incorre que estas informações se restrinjam aos municípios localizados no Estado de São Paulo. Além disso, optamos por desconsiderar a série de despesas municipais anuais por função de saúde e saneamento, que apresenta quantidade excessiva de lacunas, o que exigiria um tratamento rigoroso para avaliar um potencial problema de seleção.
} 
uma vez que estas são interrompidas em 2003. Os coeficientes de óbitos e de internações causados por doenças infecciosas e parasitárias consistem em proxy para os níveis de saneamento nos municípios. Conjuntamente ao indicador para gestações de risco e às variáveis representativas dos níveis de educação municipais, consistem nas variáveis de risco à saúde das populações de interesse.

Taxa de distorção idade-conclusão (nas escolas do ensino fundamental e médio; para mulheres e ambos os sexos), percentual de docentes com ensino superior (nas escolas de nível fundamental e médio) e taxa de abandono (também nas escolas do ensino fundamental e médio) são as variáveis representativas dos níveis de educação municipais, todas disponibilizadas pelo INEP-MEC. O amplo conjunto de variáveis representativas da educação se justifica, em primeiro lugar, pela dificuldade de encontrar um indicador anualmente calculado para todos os municípios da amostra que reflita apropriadamente o estoque de conhecimento detido pela população residente. Além disso, a relevância de cada uma destas depende em grande medida da variável dependente utilizada na estimação. Por exemplo, para o cálculo do impacto da atenção básica sobre a mortalidade infantil, os indicadores educacionais da população do sexo feminino são mais relevantes que os populacionais, enquanto para o índice de anos de vida perdidos e para as internações, não há porque limitarse aos indicadores referentes somente às mulheres residentes.

\subsection{Eficácia da Atenção Básica - Resultados Econométricos}

Num primeiro momento, tentamos ser fiéis ao máximo à metodologia e dados utilizados em Serra (2003), pois assim podemos comparar os resultados encontrados e avaliar se a utilização de amostras diferentes gera resultados substancialmente diferentes. Em seguida, realizamos as modificações propostas, seja nas variáveis ou nas observações utilizadas, com o intuito de obter resultados mais abrangentes.

Um problema constatado ao trabalharmos com a mortalidade infantil como indicador de saúde é que em municípios pequenos há variações enormes na taxa de ano para ano, o que é causado pelo baixo número de nascimentos ocorridos anualmente nestas localidades ${ }^{34}$. Sem qualquer tratamento especial, todos os coeficientes estimados são estatisticamente iguais a zero, exceto os indicadores de educação municipais e as dummies de ano ${ }^{35}$. O procedimento

\footnotetext{
${ }^{34}$ Em relação a 1999, primeiro ano da amostra, a média e o desvio padrão da mortalidade infantil nos municípios do Sudeste é de respectivamente 24,1 e 52,4 por cada mil nascidos. Já para a amostra com municípios acima de 50.000 habitantes, a média na taxa de mortalidade é de 19 por mil nascidos vivos, com desvio padrão de 5,4.

${ }^{35}$ Os resultados mencionados estão disponíveis no Anexo II, tabela II.3.
} 
adotado para atenuar esse problema (Serra, 2003) seria incorporar somente municípios com contingente populacional a partir de determinado patamar.

Tabela 2.2. Resultado das estimações - Taxa de mortalidade infantil como variável dependente (utilizando os controles de Serra, 2003)

\begin{tabular}{|c|c|c|c|}
\hline Variável & POLS & Efeitos Aleatórios & Efeitos Fixos \\
\hline PSF & $\begin{array}{c}\mathbf{1 , 1 1 3} \\
(0,936)\end{array}$ & $\begin{array}{l}\mathbf{- 0 , 0 7 2} \\
(1,012)\end{array}$ & $\begin{array}{l}\mathbf{- 2 , 3 8 9} * \\
(1,258)\end{array}$ \\
\hline PACS & $\begin{array}{l}-\mathbf{0 , 3 1 5} \\
(0,837)\end{array}$ & $\begin{array}{r}-\mathbf{0 , 3 4 7} \\
(1,117)\end{array}$ & $\begin{array}{l}-\mathbf{0 , 8 5 0} \\
(1,383)\end{array}$ \\
\hline PIBPC & $\begin{array}{c}\mathbf{0 , 0 0 0 0 8} * * * \\
(0,000019)\end{array}$ & $\begin{array}{c}\mathbf{0 , 0 0 0 0 4 8} * * \\
(0,000022)\end{array}$ & $\begin{array}{c}\mathbf{0 , 0 0 0 0 3} \\
(0,000032)\end{array}$ \\
\hline HOSP & $\begin{array}{c}\mathbf{0 , 0 5 1} \\
(0,047)\end{array}$ & $\begin{array}{c}\mathbf{0 , 0 4 8} \\
(0,077)\end{array}$ & $\begin{array}{l}\mathbf{0 , 0 5 2} \\
(0,242)\end{array}$ \\
\hline OBST & $\begin{array}{l}\mathbf{- 0 , 2 7 3} \\
(0,81)\end{array}$ & $\begin{array}{c}\mathbf{0 , 0 9 4} \\
(1,116)\end{array}$ & $\begin{array}{l}\mathbf{0 , 2 4 6} \\
(2,04)\end{array}$ \\
\hline RGEST & $\begin{array}{c}\mathbf{8 3 , 7 0 5} * * * \\
(30,743)\end{array}$ & $\begin{array}{c}\mathbf{7 5 , 4 2 5} * * * \\
(25,914)\end{array}$ & $\begin{array}{l}\mathbf{- 3 6 , 7 4 1} \\
(58,359)\end{array}$ \\
\hline DICEFM & $\begin{array}{c}\mathbf{0 , 0 7 7} * * * \\
(0,023)\end{array}$ & $\begin{array}{c}\mathbf{0 , 0 5 9} * * * \\
(0,02)\end{array}$ & $\begin{array}{l}-\mathbf{0 , 0 1 7} \\
(0,027)\end{array}$ \\
\hline DICEMM & $\begin{array}{c}\mathbf{0 , 0 8 6} * * * \\
(0,02)\end{array}$ & $\begin{array}{c}\mathbf{0 , 0 7 3} * * * \\
(0,018)\end{array}$ & $\begin{array}{c}\mathbf{0 , 0 1 4} \\
(0,023)\end{array}$ \\
\hline D00 & $\begin{array}{c}\mathbf{0 , 8 4 3} \\
(0,584)\end{array}$ & $\begin{array}{l}\mathbf{0 , 7 4 9 *} \\
(0,403)\end{array}$ & $\begin{array}{l}-\mathbf{0 , 0 8 9} \\
(0,462)\end{array}$ \\
\hline D01 & $\begin{array}{l}-\mathbf{0 , 3 3 4} \\
(0,539)\end{array}$ & $\begin{array}{l}-\mathbf{0 , 5 1 8} \\
(0,447)\end{array}$ & $\begin{array}{c}\mathbf{- 1 , 8 5 0} * * * \\
(0,545)\end{array}$ \\
\hline D02 & $\begin{array}{c}\mathbf{- 3 , 3 8 9} * * * \\
(0,792)\end{array}$ & $\begin{array}{c}-\mathbf{3 , 0 2 3} * * * \\
(0,712)\end{array}$ & $\begin{array}{c}-\mathbf{2 , 2 4 5} * * * \\
(0,825)\end{array}$ \\
\hline D03 & $\begin{array}{c}\mathbf{- 3 , 1 1 3} * * * \\
(0,831)\end{array}$ & $\begin{array}{c}-\mathbf{2 , 8 3 6} * * * \\
(0,719)\end{array}$ & $\begin{array}{c}-\mathbf{2}, \mathbf{4 7 7} * * * \\
(0,82)\end{array}$ \\
\hline _CONS & $\begin{array}{r}\mathbf{- 5 , 9 8 5} \\
(7,301) \\
\end{array}$ & $\begin{array}{l}\mathbf{- 3 , 1 5 5} \\
(6,081) \\
\end{array}$ & $\begin{array}{c}\mathbf{2 7 , 7 0 9} \\
(13,674)\end{array}$ \\
\hline $\begin{array}{l}\text { Breusch-Pagan - } \chi^{2}(1) \\
\text { Hausman }-\chi^{2}(9)\end{array}$ & & $357,66 * * *$ & $34,68 * * *$ \\
\hline $\begin{array}{l}\mathbf{R}^{2} \\
\mathbf{F}\end{array}$ & $\begin{array}{c}0,2192 \\
19,23 * * *\end{array}$ & 0,1253 & $\begin{array}{c}0,1469 \\
12.85 * * *\end{array}$ \\
\hline Observações & 1.135 & 1.135 & 1.135 \\
\hline
\end{tabular}

Notas: Erro padrão entre parênteses. ***, ** $\mathrm{e} *$ indicam significância estatística respectivamente a $1 \%, 5 \% \mathrm{e}$ $10 \%$.

Adotando como linha de corte os municípios com população superior a 50.000 habitantes no ano de 2003, obtemos os resultados dispostos na tabela 2.2. Observe que o teste LM de Breusch-Pagan indica que a hipótese nula de ausência de efeitos específicos é rejeitada a $1 \%$ de significância. Ou seja, a estimação por POLS não é a mais apropriada, sendo inclusive viesadas suas estimativas se houver presença de correlação entre o efeito específico e variáveis explicativas. O teste de Hausman, por sua vez, compara as estimativas geradas por FE e RE, ponderando pela matriz de variância e covariância. O resultado gerado indica que a 
utilização de efeitos aleatórios deve gerar estimativas inconsistentes, pois existe correlação não nula entre $f_{i}$ e $\mathbf{x}_{i t}$. Com isso, baseamos nossas conclusões na estimação por efeitos fixos.

Além das dummies de ano, a estimação por FE indica que o único coeficiente apontado como estatisticamente significante é o associado à variável PSF. Isto é, em relação à saúde infantil, podemos afirmar que o Programa Saúde da Família foi o principal responsável pela melhoria dos indicadores de saúde municipais. Em relação ao PACS, o coeficiente tem o sinal esperado, mas é estatisticamente igual a zero.

Quando flexibilizado o conjunto de variáveis de controle utilizado, seja alterando as variáveis educacionais ou incluindo proxy para a evolução do saneamento básico nos municípios, não se constata grandes alterações nos resultados, permanecendo o Programa Saúde da Família com impacto negativo sobre a mortalidade infantil. Com a especificação que julgamos a melhor dadas as informações disponíveis, que contém uma proxy para os padrões de saneamento municipal e utilizada a evasão escolar nas ensinos fundamental e médio como controle para o estoque de conhecimento disponível para os residentes e cujos resultados estão dispostos na tabela 2.3, a estimação por efeitos fixos ${ }^{36}$ indica que o coeficiente associado à cobertura do PSF é de -2,46 (redução de 2,46 óbitos infantis por mil nascidos vivos como resposta à cobertura de $100 \%$ da atenção básica comparativamente ao estado inicial de ausência de atendimento primário) e o associado ao PACS é estatisticamente igual a zero. A principal diferença em relação à especificação anterior é que o estimador do PSF torna-se significante a 5\%, assim como a evasão escolar no ensino médio.

Ou seja, pode-se afirmar que o Programa Saúde da Família exerce impacto negativo e estatisticamente significante sobre a mortalidade infantil. Em relação ao Programa de Agentes Comunitário de Saúde, o impacto é estatisticamente igual a zero, ou seja, não podemos rejeitar a hipótese de que o PACS não afete a mortalidade infantil. Uma hipótese que poderia justificar esse resultado seria o fato de que o PACS é um programa transitório, ou seja, a tendência é que uma vez que a atenção básica se consolide no município, os recursos direcionados para o PACS migrem totalmente para o PSF (Ministério da Saúde, 2001b). Outra possibilidade seria haver baixa resolutividade por parte dos agentes comunitários de saúde na ausência de profissionais de saúde mais qualificados, no que se refere ao cuidado com crianças menores que um ano. Mas, é muito importante ressaltar que esta hipótese de ser

\footnotetext{
${ }^{36}$ Os testes Breusch-Pagan e de Hausman indicam que efeitos fixos é o método de estimação mais adequado. Como o padrão encontrado nas estimações realizadas neste capítulo é de os testes mencionados indicarem sempre a consistência e eficiência de efeitos fixos e as tabelas dispõem seus resultados, somente quando a estimação não for por efeitos fixos faremos menção adiante ao método usado na estimação de interesse.
} 
baixa a eficiência do trabalho isolado do agente comunitário não passa de conjectura, sendo necessária análise mais cuidadosa para que seja confirmada ou rejeitada.

Tabela 2.3. Resultado da estimação - Taxa de mortalidade infantil como variável dependente, utilizando controles próprios

\begin{tabular}{lcccccc}
\hline \hline & Coeficiente & Erro Padrão & $\mathbf{t}$ & \multicolumn{2}{c}{ P>|t| } & \multicolumn{2}{c}{ Int. de Confiança } \\
$\mathbf{9 5 \%}$
\end{tabular}

Em relação à estimação com o índice de anos de vida perdidos como variável dependente, os testes Breusch-Pagan e de Hausman indicam que a estimação através de efeitos fixos é o método mais apropriado, assim como ocorrera em relação à taxa de mortalidade infantil. Excluímos da regressão as variáveis referentes ao número de leitos em clínicas obstétricas e à proporção de gravidezes de risco, já que são variáveis de controle específicos à saúde materno-infantil e que o índice de anos perdidos refere-se à toda a população residente com idades entre 1 e $70 \operatorname{anos}^{37}$. Os resultados da estimação ${ }^{38}$, dispostos na porção esquerda da tabela 2.4, indicam que os coeficientes associados aos PSF e PACS apresentam sinal diferente do esperado, com significância estatística respectivamente a $1 \%$ e $5 \%$.

\footnotetext{
37 A exclusão do número de leitos de clínica obstétrica da proxy de gestações de risco não provoca qualquer alteração relevante nos resultados encontrados. Importante ressaltar que ao excluir a variável número de leitos obstétricos não se incorre em omissão de variável relevante, uma vez que foi utilizado o total de leitos hospitalares como controle e esta variável já inclui os leitos voltados à especialidade obstetrícia.

${ }^{38}$ As estimações com outras variáveis de controle para os padrões educacionais nos municípios não provocam alteração significativa nos resultados e estão disponíveis mediante solicitação ao autor.
} 
Seria crível que a estratégia PACS / PSF apresentasse coeficientes estatisticamente iguais a zero, mas é de difícil compreensão como a introdução dos programas teria impacto positivo na proporção de mortes prematuras da população. O crescimento de óbitos provocados por causas externas poderia justificar o resultado encontrado, caso houvesse alguma variável não identificada que provocasse simultaneamente a elevação de mortes por causas externas e da cobertura da atenção básica. Para testar tal hipótese, estimamos o modelo considerando como variável dependente o índice de anos de vida perdidos sem computar as mortes por causas externas. Os resultados estão dispostos na parte direita da tabela 2.4 e, como se pode constatar, embora haja pequenas alterações nos coeficientes estimados, o problema do sinal contra-intuitivo permanece. Tampouco há alteração substancial nos resultados quando aplicada uma taxa de desconto sobre os anos perdidos ${ }^{39}$.

Tabela 2.4. Resultado das estimações - Índice de Anos de Vida Perdidos como variável dependente

\begin{tabular}{|c|c|c|c|c|c|c|c|c|}
\hline \multirow[t]{2}{*}{ V. Dependente } & \multicolumn{4}{|c|}{ IAVP } & \multicolumn{4}{|c|}{ IAVP Exclusive Causas Externas } \\
\hline & Coef. & Erro Pad & $\mathbf{T}$ & $P>|t|$ & Coef. & Erro Pad & $\mathbf{T}$ & $P>|t|$ \\
\hline PSF & 4,34 & 1,536 & 2,83 & 0,005 & $\mathbf{3 , 5 3}$ & 1,324 & 2,67 & 0,008 \\
\hline PACS & 4,66 & 2,731 & 1,71 & 0,088 & 5,80 & 2,354 & 2,46 & 0,014 \\
\hline PIBPC & 0,00003 & 0,00009 & 0,35 & $\mathbf{0 , 7 2 9}$ & 0,00001 & 0,00008 & 0,13 & 0,896 \\
\hline HOSP & 1,12 & 0,498 & 2,25 & 0,024 & 0,83 & 0,429 & 1,94 & $\mathbf{0 , 0 5 2}$ \\
\hline IDIPC & 0,00 & 0,001 & 2,88 & 0,004 & 0,00 & 0,001 & 3,74 & 0,000 \\
\hline DES_EF & $\mathbf{0 , 0 3}$ & 0,045 & 0,68 & 0,498 & $\mathbf{0 , 0 1}$ & 0,038 & 0,38 & $\mathbf{0 , 7 0 2}$ \\
\hline EVAS_EF & 0,11 & 0,132 & 0,84 & 0,398 & 0,16 & 0,114 & 1,44 & 0,149 \\
\hline D00 & $-3,17$ & 1,022 & $-3,10$ & 0,002 & $-2,11$ & 0,881 & $-2,39$ & $\mathbf{0 , 0 1 7}$ \\
\hline D01 & $-7,54$ & 1,156 & $-6,52$ & 0,000 & $-5,60$ & 0,996 & $-5,62$ & 0,000 \\
\hline D02 & $-8,59$ & 1,280 & $-6,71$ & 0,000 & $-8,29$ & 1,104 & $-7,51$ & 0,000 \\
\hline D03 & $-6,88$ & 1,359 & $-5,07$ & 0,000 & $-5,65$ & 1,172 & $-4,82$ & 0,000 \\
\hline CONS & 99,67 & 3,203 & 31,12 & 0,000 & 78,38 & 2,762 & 28,38 & 0,000 \\
\hline Observações & & 8320 & & & & 8320 & & \\
\hline Hausman $-\chi^{2}(10)$ & & 101,12 & & & & 57,59 & & \\
\hline Breusch-Pagan - $\chi^{2}(1)$ & & 2218,81 & & & & 1466,79 & & \\
\hline & & 0,0152 & & & & 0,0195 & & \\
\hline$F(11,6645)$ & & 9,30 & & & & 12,04 & & \\
\hline
\end{tabular}

A única explicação plausível para o resultado encontrado pode ser o fato de o PSF apresentar maior penetração em localidades de pior desenvolvimento humano, nas quais tende a haver elevada subnotificação de óbitos. Isto é, a estruturação da rede de atenção à saúde, possibilitada pelo PSF, provocaria melhora do apontamento de óbitos, o que nos levaria a inferir, com base nas séries históricas dos municípios, que a implantação e ampliação do PSF

\footnotetext{
${ }^{39}$ Estimações disponíveis no Anexo II.
} 
geram crescimento do número de óbitos. Embora este hipótese não seja exatamente testável, já que, evidentemente, não se dispõe da informação sobre a evolução da subnotificação em cada município, a estimação do impacto das variáveis de interesse sobre a mortalidade total do município pode ser um indicativo importante de sua razoabilidade. Mantendo as mesmas variáveis de controle da estimação do índice de anos de vida perdidos, a regressão por efeitos fixos ${ }^{40}$ indica que o PACS e o PSF têm impacto positivo, respectivamente, $5 \%$ e $1 \%$ de significância sobre a taxa de mortalidade do município, o que reforça a hipótese do impacto (matematicamente) negativo sobre a subnotificação. Neste caso, poder-se-ia ainda conjecturar que as estimativas do impacto sobre a mortalidade infantil também estariam subestimados, já que haveria relação negativa entre a subnotificação de óbitos e a cobertura da atenção básica, desde que a subnotificação do número de nascidos vivos fosse, em valores relativos, inferior à dos óbitos infantis ${ }^{41}$.

Uma vez explorado o impacto da atenção básica sobre os indicadores de mortalidade, resta-nos testar qual seu efeito sobre os indicadores de morbidade, representados pelo quantum e valores referentes a internações hospitalares. Considerando apenas a natureza preventiva do programa de interesse, é intuitivo esperar que haja redução na quantidade de internações, já que parte das enfermidades seriam tratadas no âmbito da atenção básica. Entretanto, o aspecto estruturante da atenção básica atua no sentido oposto, possibilitando que a rede de saúde penetre em áreas outrora desassistidas, o que deve contribuir para elevar a quantidade os encaminhamentos para as unidades de média e alta complexidade. Embora tal efeito possa ser interpretado como positivo, há que se levar em consideração que na hipótese de a equipe de saúde não dispor da infra-estrutura necessária para o exercício de suas funções, é altamente provável que haja uma incidência elevada de encaminhamento para unidades de mais alta complexidade, já que o tratamento não pode ser realizado no primeiro nível de atenção.

A tabela 2.5 mostra o resultado da estimação do PSF e PACS sobre o número de internações pagas pelo SUS, por cem mil habitantes. Com a amostra de municípios completa, os coeficientes associados ao PSF e ao PACS são estatisticamente iguais a zero e as estimativas do número de leitos hospitalares, cobertura de saneamento básico e qualidade do ensino no nível fundamental são estatisticamente significantes, todos com o sinal esperado.

\footnotetext{
${ }^{40}$ Disponível no Anexo II.

${ }^{41}$ Poder-se-ia ainda conjecturar tratar-se de caso de causalidade reversa, em que há expansão da rede de atendimento justamente em áreas com maior crescimento na incidência de óbitos precoces. Entretanto, esta hipótese parece pouco razoável, já que a tendência é de redução dos óbitos por outras causas que não as externas, devido à melhora da tecnologia disponível.
} 
Seguindo o padrão da estratégia de estimação do impacto sobre a mortalidade infantil, excluiremos os municípios menores da amostra por considerar que nestes há possibilidade de o comportamento estocástico da variável dependente ser excessivamente forte (devido à base populacional reduzida), o que pode ocasionar pouca aderência dos dados ao modelo teórico. À esquerda da tabela 2.5 situam-se os resultados para a amostra completa de municípios e, à direita, estão dispostas as estimações para a amostra que considera somente os municípios com população superior a 50.000 habitantes. $\mathrm{Na}$ amostra que considera apenas os municípios grandes, tratamento dispensado também à estimação com mortalidade infantil como variável dependente, há mudança considerável nos resultados obtidos: o coeficiente associado ao PSF é positivo e estatisticamente significante, ao passo que não se pode afirmar que os demais sejam diferentes de zero, com exceção da quantidade de leitos hospitalares disponíveis, que têm o sinal positivo esperado.

Tabela 2.5: Resultado das estimações - AIH pagas por 100.000 habitantes como variável dependente

\begin{tabular}{|c|c|c|c|c|c|c|c|c|}
\hline \multirow{2}{*}{ AIH Pagas } & \multicolumn{4}{|c|}{ Amostra completa } & \multicolumn{4}{|c|}{ Municípios com pop. > $\mathbf{5 0 . 0 0 0}$} \\
\hline & Coef. & Erro Pad & $\mathbf{t}$ & $\mathbf{P}>|\mathbf{t}|$ & Coef. & Erro Pad & $\mathbf{t}$ & $\mathbf{P}>|\mathbf{t}|$ \\
\hline PSF & $-150,40$ & 197,90 & $-0,76$ & 0,447 & 684,25 & 218,40 & 3,13 & 0,002 \\
\hline PACS & $-15,95$ & 351,90 & $-0,05$ & 0,964 & 305,08 & 239,50 & 1,27 & 0,203 \\
\hline PIBPC & $-0,0026$ & 0,0116 & $-0,22$ & $\mathbf{0 , 8 2 2}$ & $-0,0020$ & 0,0057 & $-0,35$ & $\mathbf{0 , 7 2 6}$ \\
\hline HOSP & 228,80 & 64,18 & 3,56 & 0,000 & 203,74 & 37,88 & 5,38 & $\mathbf{0 , 0 0 0}$ \\
\hline ODIPC & 5,94 & 2,35 & 2,53 & 0,012 & 2,19 & 3,88 & 0,56 & 0,573 \\
\hline DICEFG & 9,82 & 5,37 & 1,83 & 0,068 & 5,91 & 5,08 & 1,17 & 0,244 \\
\hline DES_EF & $-36,62$ & 5,76 & $-6,36$ & 0,000 & $-8,60$ & 6,19 & $-1,39$ & 0,165 \\
\hline D00 & 202,79 & 133,12 & 1,52 & 0,128 & $-142,69$ & 71,38 & $-2,00$ & 0,046 \\
\hline D01 & $-67,94$ & 153,53 & $-0,44$ & 0,658 & $-455,93$ & 90,99 & $-5,01$ & 0,000 \\
\hline D02 & $-322,71$ & 178,82 & $-1,80$ & 0,071 & $-712,75$ & 139,46 & $-5,11$ & $\mathbf{0 , 0 0 0}$ \\
\hline D03 & $-336,78$ & 178,61 & $-1,89$ & 0,059 & $-872,43$ & 141,26 & $-6,18$ & 0,000 \\
\hline CCONS & 8949,66 & 456,74 & 19,59 & 0,000 & 7221,06 & 492,94 & 14,65 & 0,000 \\
\hline Observações & \multicolumn{4}{|c|}{8315} & \multicolumn{4}{|c|}{1135} \\
\hline Hausman - $\chi^{2}(10)$ & \multicolumn{4}{|c|}{107,49} & \multicolumn{4}{|c|}{41,04} \\
\hline Breusch-Pagan - $\chi^{2}(1)$ & \multicolumn{4}{|c|}{2766,20} & \multicolumn{4}{|c|}{1499,30} \\
\hline $\mathbf{R}^{2}$ & \multicolumn{4}{|c|}{0,0164} & \multicolumn{4}{|c|}{$\mathbf{0 , 2 3 1 1}$} \\
\hline $\mathbf{F}$ & \multicolumn{4}{|c|}{$F(11,6640)$} & \multicolumn{2}{|c|}{$\mathbf{F}(\mathbf{1 1 , 8 9 7 )}$} & \multicolumn{2}{|c|}{12,04} \\
\hline
\end{tabular}

Ou seja, a partir dos resultados obtidos nos grandes municípios, pode-se inferir que o aspecto preventivo da atenção básica não está gerando os resultados desejados, em termos de internações hospitalares. Interessante notar que, de acordo com os resultados, o impacto depende da magnitude dos municípios: se nos municípios com população superior a 50.000 habitantes, a estruturação da atenção básica provoca crescimento na quantidade de internações, o mesmo não ocorre nos municípios menores, em que o impacto é 
estatisticamente igual a zero. Além da questão da maior intensidade do comportamento estocástico nos municípios pequenos, outra hipótese plausível para explicação do fenômeno constatada seria a de que há uma disposição de as equipes localizadas nos municípios maiores encaminharem os pacientes para os hospitais com maior freqüência, dada a tendência de haver hospital no próprio município ${ }^{42}$. Ou seja, um fator determinante para que haja crescimento do número de internações seria a presença de hospital no município. Podemos testar essa hipótese avaliando se há diferença significativa na resposta do quantum de internações pagas à cobertura da atenção básica entre municípios com ou sem hospitais. Com base nessa abordagem, confirmamos a diferença na resposta entre os dois grupos de municípios: naqueles em que há hospitais, o efeito é positivo e estatisticamente significante para o PACS (coeficiente igual a 558,9) e PSF $(447,6)$, ao passo em que nos municípios em que não existe atendimento de maior complexidade, o impacto dos programas da atenção básica é estatisticamente igual a zero, embora com sinal negativo (o coeficiente associado ao PACS é igual a -386,9 e o associado ao PSF é -527,1). A diferença se mantém quando comparados os dois grupos de municípios considerando única e exclusivamente as localidades com menos de 50.000 habitantes ${ }^{43}$, o que nos sugere que a presença de hospital é o elemento preponderante para a diferença nos resultados e não o maior desvio padrão observado nos municípios menores.

Naturalmente, este fenômeno tem implicações importantes para efeito de finanças públicas: se a atenção básica exerce um impacto positivo sobre a produção das unidades de maior complexidade, o impacto financeiro dos programas de baixa complexidade sobre as contas públicas não pode ser mensurado apenas pelo custo de seu financiamento direto, mas também pela elevação de despesa nos outros níveis de complexidade. Uma forma de mensurar este efeito é avaliar o impacto dos programas de interesse sobre o valor total pago pelas internações a que foram submetidos os residentes de cada município, estimação essa que está disposta na tabela 2.6.

\footnotetext{
${ }^{42}$ Cerca de metade dos municípios com até 50.000 habitantes não dispunham de leitos hospitalares em 2003, ao passo que em $97 \%$ dos municípios com população superior a esse corte havia ao menos um hospital.

${ }^{43}$ Resultados completos disponíveis no Anexo II.
} 
Tabela 2.6: Resultado das estimações - Valor Total das AIH pagas per capita como variável dependente

\begin{tabular}{|c|c|c|c|c|c|c|c|c|}
\hline \multirow{2}{*}{$\begin{array}{c}\text { Valor Total } \\
\text { despendido em AIHs }\end{array}$} & \multicolumn{4}{|c|}{ Amostra Completa } & \multicolumn{4}{|c|}{ Municípios com pop. > 50.000} \\
\hline & Coef. & Erro Pad & $\mathbf{t}$ & $\mathbf{P}>|\mathbf{t}|$ & Coef. & Erro Pad & $\mathbf{t}$ & $\mathbf{P}>|\mathbf{t}|$ \\
\hline PSF & $-1,03$ & 0,877 & $-1,17$ & 0,241 & 3,59 & 0,970 & 3,70 & $\mathbf{0 , 0 0 0}$ \\
\hline PACS & $-0,12$ & 1,559 & $-0,07$ & 0,941 & 2,03 & 1,064 & 1,91 & $\mathbf{0 , 0 5 7}$ \\
\hline PIBPC & $-0,00001$ & 0,00005 & $-0,20$ & $\mathbf{0 , 8 4 2}$ & $\mathbf{0 , 0 0 0 0 3}$ & 0,00003 & 1,01 & $\mathbf{0 , 3 1 0}$ \\
\hline HOSP & 1,39 & 0,284 & 4,88 & $\mathbf{0 , 0 0 0}$ & 1,25 & 0,168 & 7,45 & $\mathbf{0 , 0 0 0}$ \\
\hline ODIPC & 0,04 & 0,010 & 4,17 & $\mathbf{0 , 0 0 0}$ & $\mathbf{0 , 0 1}$ & 0,017 & 0,79 & 0,428 \\
\hline DICEFG & $\mathbf{0 , 0 4}$ & 0,024 & 1,67 & $\mathbf{0 , 0 9 5}$ & $-0,02$ & 0,023 & $-0,73$ & 0,466 \\
\hline DES_EF & $-0,12$ & 0,025 & $-4,77$ & $\mathbf{0 , 0 0 0}$ & $\mathbf{0 , 0 1}$ & 0,027 & 0,36 & 0,721 \\
\hline D00 & $-1,15$ & 0,590 & $-1,95$ & $\mathbf{0 , 0 5 2}$ & $-3,28$ & 0,317 & $-10,35$ & $\mathbf{0 , 0 0 0}$ \\
\hline D01 & $-3,33$ & 0,680 & $-4,90$ & $\mathbf{0 , 0 0 0}$ & $-5,86$ & 0,404 & $-14,49$ & $\mathbf{0 , 0 0 0}$ \\
\hline D02 & $-5,81$ & 0,792 & $-7,34$ & $\mathbf{0 , 0 0 0}$ & $-7,18$ & 0,619 & $-11,60$ & $\mathbf{0 , 0 0 0}$ \\
\hline D03 & $-8,27$ & 0,791 & $-10,46$ & $\mathbf{0 , 0 0 0}$ & $-10,56$ & 0,627 & $-16,84$ & 0,000 \\
\hline CONS & 30,12 & 2,021 & 14,90 & 0,000 & 26,02 & 2,189 & 11,89 & $\mathbf{0 , 0 0 0}$ \\
\hline Observações & \multicolumn{4}{|c|}{8317} & \multicolumn{4}{|c|}{1135} \\
\hline Hausman - $\chi^{2}(10)$ & \multicolumn{4}{|c|}{102,45} & \multicolumn{4}{|c|}{27,86} \\
\hline Breusch-Pagan - $\chi^{2}(1)$ & \multicolumn{4}{|c|}{3634,45} & \multicolumn{4}{|c|}{1355,90} \\
\hline $\mathbf{R}^{2}$ & \multicolumn{4}{|c|}{$\mathbf{0 , 0 6 3 2}$} & \multicolumn{4}{|c|}{0,6562} \\
\hline $\mathbf{F}$ & \multicolumn{2}{|c|}{$\mathrm{F}(11,6642)$} & \multicolumn{2}{|c|}{40,76} & \multicolumn{2}{|c|}{$\mathbf{F}(\mathbf{1 1}, \mathbf{8 9 7})$} & \multicolumn{2}{|c|}{155,63} \\
\hline
\end{tabular}

Os resultados apresentados são similares àqueles em que o quantum de AIH pagas é a variável dependente. No que se refere aos coeficientes associados às variáveis de controle, as estimações apresentam os mesmo sinais, com exceção da renda e do percentual de docentes com superior que, no entanto, são estatisticamente iguais a zero. Para a amostra completa de municípios, não pode rejeitar-se que o impacto de PSF e PACS sejam iguais a zero, mas no caso dos municípios com mais de 50.000 habitantes, ambos são positivos, com significância estatística de $1 \%$ e $10 \%$, respectivamente. No contexto dos municípios maiores, o Programa Saúde da Família eleva os gastos com alta complexidade em $\mathrm{R} \$ 3,59$ per capita, a valores de 1999 e o Programa de Agentes Comunitários em R \$2,03 ${ }^{44}$.

A similaridade dos resultados (no que se refere aos sinais) entre as estimações com o quantum de AIH pagas e o correspondente valor total despendido pelo SUS pode ser um indicativo de que o mesmo fator - a presença de hospital no próprio município - é determinante para o impacto da política de atenção básica sobre as internações. Para reforçar tal afirmação, foram estimadas novamente as amostras separadamente (com e sem hospital) ${ }^{45}$ e verificado que: o PSF tem impacto matematicamente positivo ( $\mathrm{R} \$ 1,85$ por habitante) e

\footnotetext{
${ }^{44} \mathrm{O}$ valor referente ao PSF equivale a R \$ 8,43 a preços correntes de 2008, com correção pelo IGP-M médio do ano. Para o ano de 2008, considerou-se somente a média do índice de preços até o mês de maio. No caso do PACS, o valor a preços correntes seria de $\mathrm{R} \$ 4,77$.

${ }^{45}$ Estimações disponíveis no anexo II.
} 
estatisticamente diferente de zero (a 5\% de significância) sobre o valor total despendido em internações nos municípios dotados de hospital, enquanto nos municípios sem unidades de alta complexidade, o programa reduz o dispêndio em $\mathrm{R} \$ 2,85$ per capita ao ano. No caso do PACS, para cada amostra, são mantidos os mesmos sinais do PSF, porém, em ambas as amostras não se pode afirmar que o impacto seja diferente de zero. Para exame da robustez desta conclusão, verificou-se ainda se a diferença ocorre quando comparados somente os municípios pequenos com e sem hospitais, confirmando-se que perdura a discrepância. No caso de municípios pequenos com hospitais, os impactos dos programas de interesse sobre o valor total pago nas internações foram estatisticamente iguais a zero (com sinal positivo) e quando considerados somente os pequenos sem hospital, o impacto do PSF foi de -2,88, com significância estatística a 10\%, e o do PACS foi de -1,65, mas estatisticamente igual a zero.

Um resultado comum a todas as estimações realizadas e interessante de ser destacado consiste no fato de o impacto direto da renda per capita sobre os indicadores de saúde ser estatisticamente igual a zero em praticamente todas as regressões ${ }^{46}$. Em concordância com por outros estudos (Hanratty, 1996; Filmer \& Pritchett, 1999; e Serra, 2003), este resultado não implica em que a renda seja uma variável irrelevante, mas demonstra que esta é um fator importante para os níveis de saúde sobretudo na medida em que viabiliza o consumo de outros itens relacionados à saúde, como saneamento básico e atendimento médico. Ou seja, quando esses fatores são controlados nas regressões o impacto da renda torna-se menos importante.

\footnotetext{
${ }^{46}$ A exceção é a estimação por efeitos fixos do impacto da atenção básica sobre a mortalidade materna na amostra de municípios com menos de 50.000 habitantes.
} 


\section{CAPÍTULO III - GESTÃo E IRREGULARIDADES NO ÂMBITO DA EXECUČ̃̃o DeSCENTRALIZAda da POLÍTICA DE ATENČ̃̃o BÁSICA}

O presente capítulo tem como objetivo analisar as irregularidades constatadas pela Controladoria-Geral da União (CGU) na gestão municipal das políticas voltadas para a atenção básica em saúde. São examinados os resultados das auditorias realizadas, no âmbito de seu Programa de Fiscalização a Partir de Sorteios Públicos, em 178 municípios localizados na Região Sudeste.

A abordagem adotada tem como objetivo analisar a qualidade do gasto realizado nas ações em saúde executadas pelos municípios, e encontra-se alinhada à preocupação dispensada pelos policy-makers, estudiosos e população em geral, em relação à gestão adequada e eficiente dos recursos públicos. Embora este seja um fenômeno com especial relevância no Brasil, devido à tendência de crescimento da carga tributária verificada nos últimos $\operatorname{anos}^{47}$, a eficiência na gestão dos recursos na administração pública consiste em tema de reconhecida relevância no mundo, inclusive nos países desenvolvidos.

A emergência deste debate no interior da teoria econômica foi motivada, principalmente, pelos persistentes déficits fiscais que permearam as economias de diversos países no mundo durante as décadas de 1980 e 1990, o que estimulou a investigação acerca das suas causas e implicações. Isto incorreu no aprofundamento da discussão acerca dos mecanismos e incentivos através dos quais os governos utilizam os recursos arrecadados, concluindo-se que interações estratégicas e informação incompleta seriam os principais elementos que possibilitariam a formação e manutenção de déficit público e de resultados subótimos na alocação dos recursos ${ }^{48}$. Neste processo, questões como o papel de fatores políticos e institucionais no resultado das políticas públicas, ainda pouco exploradas na esfera tradicional da ciência econômica, foram incorporadas de forma mais ativa à literatura. Procedimentos referentes à aprovação do orçamento público, efeitos negativos da corrupção e

\footnotetext{
${ }^{47}$ Secretaria de Receita Federal, 2006.

${ }^{48}$ São diversas as formas em que este fenômeno poderia ocorrer: (i) um líder eleito pode elevar os gastos para que, de acordo com a equivalência ricardiana, seu sucessor tenha menos graus de liberdade na sua gestão, pois o último seria obrigado a elevar impostos e cortar gastos para viabilizar o pagamento da dívida contraída por seu antecessor; (ii) quando mais de um grupo político detém o poder, pode haver discordância sobre como dividir o ônus de reduzir o déficit e o processo de ajuste pode ser retardado à medida que cada grupo tenta infligir a outros uma parcela desproporcional; (iii) gestores menos hábeis na administração de recursos públicos, ou seja, que geram uma quantidade subótima de bens públicos dado determinado nível de impostos, podem recorrer a empréstimos para elevar os gastos e tentar camuflar da população a ineficiência de sua gestão (Romer, 2001).
} 
vantagens da transparência fiscal são temas que se tornaram cada vez mais presentes nas análises econômicas.

Focando nos procedimentos associados ao desenho, aprovação e implementação do orçamento público, Alesina (1999) conclui que diferenças nestes procedimentos são fundamentais para a compreensão dos resultados fiscais. Para este autor, estruturas de poder mais hierarquizadas, a presença de leis (ou restrições de crível execução) limitando o tamanho do déficit, assim como maior transparência e controle nos procedimentos orçamentários são elementos que promovem disciplina fiscal. Este resultado reforça a importância da transparência fiscal para a obtenção de resultados eficientes por parte do setor público. Além da inequívoca importância da transparência governamental no processo político, esta consiste em fator crucial para a gestão eficiente dos recursos públicos, na medida em que a existência de assimetrias informacionais entre o governo e os eleitores impede que haja monitoramento efetivo das decisões tomadas pelos gestores públicos. Logo, transparência nas operações governamentais é considerada uma condição fundamental para a sustentabilidade fiscal, boa governança e retidão na condução da política fiscal ${ }^{49}$.

Embora a transparência fiscal possua diversos aspectos, esta pode ser definida, grosso modo, como a ampla abertura ao público das estruturas e funções de governo, intenções de política fiscal, contas do setor público e suas projeções (Kopits, 2000). Ela implica acesso a informações confiáveis, compreensíveis, atualizadas e comparáveis acerca das atividades governamentais. Desta maneira, o eleitorado e mercados financeiros podem analisar de forma apurada tanto a situação das contas públicas quanto os reais custos e benefícios das atividades governamentais. Além dos efeitos positivos sobre o resultado fiscal agregado, questão que a princípio motivara uma análise mais profunda do tema, maior transparência engendra maior produtividade dos gastos públicos.

No Brasil, a transparência das operações governamentais é geralmente incipiente, sobretudo nas esferas subnacionais. No entanto, houve avanços significativos nos últimos anos, principalmente no que se refere ao governo federal. No contexto de adoção de medidas visando o controle mais efetivo dos recursos sob sua responsabilidade e dotar sua estrutura de maior transparência, insere-se a criação da Controladoria Geral da União (CGU), em 2001. De acordo com as informações disponíveis em http://www.cgu.gov.br ${ }^{50}$, o órgão tem como

\footnotetext{
${ }^{49}$ Kopits, 2000.

${ }^{50}$ Acessado em 20 de Janeiro de 2008.
} 
funções o controle, correição, prevenção da corrupção e ouvidoria, no que se refere à gestão e o patrimônio públicos.

\subsection{Descrição dos Municípios e Relatórios Utilizados}

Dentre as atividades de responsabilidade da CGU, se destaca o programa de fiscalização, em estados e municípios, a partir de sorteios públicos. O objetivo de tais fiscalizações é detectar eventuais irregularidades na aplicação de recursos públicos repassados pela União para a execução descentralizada de programas federais, estimulando tanto maior participação da sociedade civil no controle dos recursos empregados quanto a adoção, pelos gestores estaduais e municipais, de práticas mais rigorosas de controle que assegurem a devida aplicação do dinheiro público. Assim que concluídos, estes relatórios são disponibilizados na página virtual da CGU e encaminhados a diversos órgãos da administração pública, para a adoção de providências cabíveis.

A seleção de unidades a serem fiscalizadas é realizada mediante sorteio empreendido pela Caixa Econômica Federal. Estes são acompanhados por representantes da sociedade civil e efetuados pelos mesmos equipamentos utilizados nas loterias, o que atesta imparcialidade e isenção de ingerência política na decisão de escolha, o que, caso ocorresse, poderia gerar algum viés nos resultados. As referidas fiscalizações tiveram início em 2003, num caráter experimental, e após ajustes, o programa adotou seu formato definitivo: são escolhidos, a cada sorteio, 60 municípios de até 300.000 habitantes. Os relatórios expõem as irregularidades associadas à execução de programas federais implementados de forma descentralizada e em que haja repasses vinculados da União. Logo, os programas associados à estratégia de atenção básica de saúde organizada pelo Ministério da Saúde, foco deste trabalho, são alvo das fiscalizações da CGU. Afinal, ainda que sua execução esteja sob responsabilidade dos municípios, estes recebem repasses da União através das partes fixa e variável do PAB (Piso Assistencial Básico) ou através de convênios.

Informações referentes a três programas integrantes da estratégia de atenção básica foram sistematizadas com base nos mencionados relatórios. São eles: o Atendimento Assistencial nos Municípios Brasileiros (também descrito como PAB-Fixo ${ }^{51}$ ); o Programa Saúde da Família (financiado pela parte variável do Piso da Atenção Básica - PAB); e a Estruturação da Rede de Serviços de Atenção Básica de Saúde. Embora seja pouco prudente

\footnotetext{
51 Ao longo do trabalho, utilize-se o nome PAB-Fixo para fazer referência ao Programa de Atendimento Assistencial nos Municípios Brasileiros, já que o PAB-Fixo destina-se exclusivamente ao financiamento das ações previstas neste programa.
} 
afirmar que a escolha em focar nestes três programas tenha ocorrido devido à importância superior em relação aos demais, pode-se argumentar que estes compõem o núcleo duro da estratégia de atenção básica.

O PSF é reconhecido pelo Ministério da Saúde "como estruturante para a organização dos sistemas municipais de saúde” e já foi discutido com detalhe nos capítulos anteriores $^{52}$.

O PAB-Fixo, embora destinado a variadas ações de atenção básica (como pagamento de pessoal, aquisição de equipamento, material para utilização nas Unidades Básicas de Saúde e medicamentos), exige, em tese ${ }^{53}$, uma série de condicionantes que dotam os municípios de estrutura administrativa para executar as ações em saúde de forma mais eficiente e alinhada com as diretrizes do SUS. Entre essas condicionalidades se destacam a exigência de elaboração do Plano Municipal de Saúde e do Relatório de Gestão, assim como o adequado funcionamento de Conselho Municipal de Saúde (CMS). O Plano Municipal de Saúde consiste no documento no qual são previstas as atividades e programações do sistema municipal de saúde num horizonte de quatro anos ${ }^{54}$. Grosso modo, o planejamento das ações em saúde prevê o levantamento das principais carências do sistema de saúde, o estabelecimento das principais diretrizes, instrumentos de ação, objetivos quantitativos e os recursos financeiros que serão disponibilizados para a consecução do planejado. O Relatório de Gestão é o documento de prestação de contas das ações de saúde executadas no município, que deve ser realizado anualmente e requer aprovação pelo CMS. Além da óbvia importância de dotar o município de planejamento para as ações de saúde, ambos os documentos são importantes na medida em que reduzem a assimetria de informações entre o principal financiador das ações em saúde (Ministério da Saúde) e o agente executor (secretarias municipais de saúde). A existência e funcionamento de Conselho Municipal de Saúde também é exigência para o recebimento dos recursos do $\mathrm{PAB}^{55}$. Os conselhos de saúde são considerados essenciais para o controle social do $\mathrm{SUS}^{56}$, ou seja, para que haja alinhamento das ações executadas com as principais demandas da população. Isso porque a legislação estabelece que os conselhos sejam formados por representantes de usuários, de trabalhadores do SUS e de representantes do governo (prestadores de serviços conveniados são incluídos neste último), com distribuição das vagas de, respectivamente, $50 \%$, 25\% e $25 \%$ para cada um

\footnotetext{
${ }^{52}$ Política Nacional de Atenção Básica p. 16 (Ministério da Saúde, 2006).

${ }^{53}$ Norma Operacional Básica do Sistema Único de Saúde (NOB/SUS) 01/1996.

${ }^{54}$ Lei 8.080 , art. $36, \S 1^{\circ}$.

${ }^{55}$ Norma Operacional Básica do Sistema Único de Saúde (NOB/SUS) 01/1996.

${ }^{56}$ Resolução 333-2003.
} 
desses grupos. O funcionamento e composição adequados dos conselhos municipais minimizam a assimetria de informação existente entre os gestores municipais e seus eleitores.

A Estruturação da Rede de Serviços de Atenção Básica, terceiro programa considerado, consiste basicamente no estabelecimento de convênios entre as secretarias municipais e o Ministério da Saúde, voltados à realização de investimentos em infra-estrutura e à aquisição de equipamentos que dotem os municípios da capacidade física necessária para executar as ações de saúde previstas. Eventualmente, as secretarias estaduais também participam desses convênios. Dentre os principais objetos de convênios destacam-se: a construção ou reforma de unidades básicas de saúde; a compra de unidades móveis de saúde (ambulâncias); e aquisição de material e equipamentos voltados à atenção primária de saúde.

As irregularidades relatadas foram padronizadas, de forma que pudessem ser sistematizadas e ordenadas em termos de incidência ${ }^{57}$. Para a viabilização deste objetivo, foram criadas categorias que agregassem os desvios de natureza similar na mesma classificação. A criação destas classificações consistiu no maior desafio desta pesquisa, afinal, a fonte primária consiste em relatórios descritivos, os quais naturalmente não exibem um padrão exato, seja na nomenclatura atribuída a cada irregularidade constatada ou até na definição do que consiste ou não em impropriedade. Não há homogeneidade quanto à profundidade da análise, em alguns casos, são detalhados todos os itens em que foram detectados desvios e seus respectivos valores, em outros, são citados somente em linhas gerais. Em função desta característica dos relatórios, optou-se por focar a investigação nos aspectos qualitativos das informações contidas nos relatórios da $\mathrm{CGU}^{58}$. O critério de agregação das irregularidades tentou atender ao objetivo de consolidá-las ao máximo sem incorrer na perda de informações relevantes. Embora pareça excessivamente arbitrário à primeira análise, sem a consolidação haveria centenas de irregularidades, simultaneamente diferentes e similares, o que seria de pouca utilidade para qualquer análise posterior. Por outro lado, a agregação de forma excessiva incorreria na perda de dados relevantes, os quais poderiam servir de base para posterior análise.

\footnotetext{
${ }^{57}$ Incidência $=\mathrm{N}^{\mathrm{o}}$. de ocorrências $/$ Total de Municípios em que o programa em questão foi fiscalizado.

${ }^{58}$ Em função do fato de as informações disponíveis serem pouco precisas para um enfoque quantitativo, que se adotou o cuidado ao longo deste trabalho em não utilizar a expressão eficiência da política de atenção básica. Além disso, ficou impossibilitada ainda a utilização do instrumental econométrico para estimar o impacto das irregularidades constatadas sobre os indicadores municipais de saúde, pois uma condição chave para que os estimadores calculados sejam consistentes é a de que as variáveis explicativas sejam exógenas a variável dependente, característica esta que dificilmente pode atribuída aos desvios realizados pelos gestores.
} 
Foram abrangidos neste trabalho os 178 municípios da Região Sudeste que foram fiscalizados entre os $12^{\circ}$ e $22^{\circ}$ sorteios empreendidos pela CGU, que ocorreram entre agosto de 2004 e julho de $2006^{59}$. Do total de municípios considerados, em 169 era executado, no mínimo, um dos programas que são objeto desta pesquisa. Desses, 10 se situam no Espírito Santo, 76 em Minas Gerais, 20 no Rio de Janeiro e 63 em São Paulo. A tabela 3.1 dispõe a média de suas principais características socioeconômicas vis-à-vis àquelas do universo dos municípios brasileiros e da Região Sudeste. A tabela 3.2 informa a composição média da receita total dos municípios frente ao total no Brasil e na Região Sudeste.

Tabela 3.1. Características geográficas e populacionais médias dos municípios auditados, do total de municípios do Sudeste e do total de municípios do Brasil

\begin{tabular}{lccc}
\hline \hline & Auditados & Sudeste & Brasil \\
\hline \hline Área geográfica $\left(\mathrm{Km}^{2}\right)$ & 540 & 555 & 1543 \\
Distância à capital estadual & 260 & 261 & 253 \\
Médicos Residentes (por mil habitantes) & 0,43 & 0,41 & 0,27 \\
Índice de Desenvolvimento Humano & 0,75 & 0,74 & 0,70 \\
Índice de Gini & 0,55 & 0,54 & 0,56 \\
População Residente & 28245 & 43465 & 30833 \\
Percentual da população em área urbana & $85,0 \%$ & $90,5 \%$ & $81,3 \%$ \\
\hline \hline
\end{tabular}

Fonte: IBGE (2000).

Com base nas informações dispostas nas tabelas 3.1 e 3.2, pode-se verificar que os municípios auditados são representativos da localidade média da Região Sudeste. Os resultados acerca das variáveis geográficas e populacionais dispostas são similares, com exceção da população residente média e do percentual da população residente nas áreas urbanas. A diferença no contingente populacional já era esperada, uma vez que os sorteios da CGU abrangem somente os municípios com população de até 300.000 habitantes. A referente à proporção de habitantes em área urbana deriva da correlação positiva entre esta e o número de habitantes $(\rho=0,14$ no Sudeste). Em relação à estrutura de arrecadação, o grupo da totalidade dos municípios do Sudeste tem ligeira vantagem na capacidade de geração de receita própria, mas a diferença tampouco é significativa (inferior a um ponto percentual). $\mathrm{Na}$ comparação com o total de municípios brasileiros, o grupo auditado apresenta, assim como a totalidade localizada na Região Sudeste, indicadores socioeconômicos melhores e menor dependência de transferências governamentais de estados e da União, na média.

\footnotetext{
59 A amostra de municípios considerada e os respectivos relatórios de fiscalização podem ser obtidos em http://www.cgu.gov.br.
} 
Tabela 3.2. Composição da receita total: municípios auditados, total de municípios do Sudeste e do Brasil (2005)

\begin{tabular}{lccc}
\hline \hline & Auditados & Sudeste & Brasil \\
\hline 1. Receitas Correntes & $\mathbf{9 8 , 2 \%}$ & $\mathbf{9 7 , 8 \%}$ & $\mathbf{9 7 , 5 \%}$ \\
\hline 1.1 Receita Tributária & $7,3 \%$ & $7,5 \%$ & $5,7 \%$ \\
1.1.1 IPTU & $2,0 \%$ & $2,3 \%$ & $1,3 \%$ \\
1.1.2 ISS & $2,6 \%$ & $2,5 \%$ & $2,0 \%$ \\
1.1.3 Taxas & $1,0 \%$ & $1,0 \%$ & $0,7 \%$ \\
1.1.4 Outras Receitas Tributárias & $1,6 \%$ & $1,6 \%$ & $1,6 \%$ \\
\hline 1.2 Outras Rec. Correntes Próprias & $7,3 \%$ & $7,6 \%$ & $5,5 \%$ \\
\hline 1.3 Rec. de Transferências Correntes & $83,6 \%$ & $82,7 \%$ & $86,3 \%$ \\
1.3.1 FPM & $34,5 \%$ & $36,2 \%$ & $38,8 \%$ \\
1.3.2 SUS & $4,7 \%$ & $4,6 \%$ & $6,1 \%$ \\
1.3.3 FNAS & $0,3 \%$ & $0,3 \%$ & $0,7 \%$ \\
1.3.4 FNDE & $1,5 \%$ & $1,5 \%$ & $1,9 \%$ \\
1.3.5 ICMS & $24,0 \%$ & $22,7 \%$ & $18,8 \%$ \\
1.3.6 IPVA & $2,0 \%$ & $2,0 \%$ & $1,3 \%$ \\
1.3.7 FUNDEF & $9,6 \%$ & $9,4 \%$ & $12,8 \%$ \\
1.3.8 Convênios SUS & $0,3 \%$ & $0,3 \%$ & $0,4 \%$ \\
1.3.9 Outros Convênios & $1,6 \%$ & $1,4 \%$ & $1,4 \%$ \\
1.3.10 Outras Transferências Correntes & $5,2 \%$ & $4,4 \%$ & $4,1 \%$ \\
\hline $\mathbf{2 .}$ Receitas de Capital & $\mathbf{1 , 8 \%}$ & $\mathbf{2 , 2 \%}$ & $\mathbf{2 , 5 \%}$ \\
\hline \hline
\end{tabular}

Fonte: Secretaria do Tesouro Nacional.

Vale destacar que, embora a situação dos municípios auditados seja pouco melhor que a do município brasileiro médio, a estrutura da composição de receitas dos municípios é ainda extremamente dependente das transferências governamentais. Isto deriva da estrutura tributária centralizada, em que os principais impostos são de competência da União (como IR, COFINS e IPI) ou dos estados (destaque para o ICMS). O grande problema subjacente a este modelo é que ele gera um incentivo reduzido para a cobrança, por parte dos munícipes, acerca da otimização dos recursos disponíveis para as prefeituras, já que seu custo de captação é socializado com o país inteiro.

Dos 169 municípios auditados e dotados de sistema de atenção básica de saúde, em 133 havia o Programa de Saúde da Família, do qual foram criadas 16 categorias de irregularidades. O PAB-Fixo, por sua vez, gerou 19 itens, num total de 156 municípios auditados. O Programa Estruturação da Rede de Serviços de Atenção Básica foi objeto de análise numa quantidade inferior de municípios (79), com a criação do total de 14 classificações de impropriedades.

Para a discussão das irregularidades concernentes a cada um dos programas componentes do núcleo duro da estratégia de atenção básica de saúde, destinamos as três 
próximas seções do capítulo. Para uma consulta mais sistematizada, o anexo da dissertação dispõe as tabelas que com as descrições de cada uma das categorias criadas, além de exemplos das principais irregularidades que as integram e, eventualmente, da legislação descumprida.

Tabela 3.3. Irregularidades no âmbito do Programa de Saúde da Família

\begin{tabular}{|c|c|c|}
\hline Irregularidade & Qtde & Incidência \\
\hline $\begin{array}{l}\text { Não é atendido o estabelecido no desenho do programa acerca da razão de } \\
\text { famílias atendidas por equipes de saúde ou seus componentes }\end{array}$ & 43 & $32,33 \%$ \\
\hline $\begin{array}{l}\text { Equipes de Saúde da Família (ESF) não dispõem de infra-estrutura } \\
\text { adequada para execução de seus trabalhos }\end{array}$ & 38 & $28,57 \%$ \\
\hline Monitoramento insuficiente das Equipes de Saúde da Família. & 38 & $28,57 \%$ \\
\hline Inconsistência nos dados do SIAB & 33 & $24,81 \%$ \\
\hline Irregularidades na contratação de profissionais ou na constituição das ESF & 28 & $21,05 \%$ \\
\hline $\begin{array}{l}\text { Capacitação inexistente ou insuficiente para ACS e demais integrantes das } \\
\text { ESF contratados }\end{array}$ & 25 & $18,80 \%$ \\
\hline $\begin{array}{l}\text { Ações previstas no desenho do programas não são executadas } \\
\text { adequadamente no município }\end{array}$ & 20 & $15,04 \%$ \\
\hline $\begin{array}{l}\text { Irregularidades no gerenciamento de medicamentos e materiais para uso } \\
\text { exclusivo das ESF }\end{array}$ & 9 & $6,77 \%$ \\
\hline Contratação irregular de organização executora do programa & 8 & $6,02 \%$ \\
\hline Planejamento deficiente para implantação, execução e expansão do PSF & 8 & $6,02 \%$ \\
\hline $\begin{array}{l}\text { Desvio de finalidade na aplicação de recursos financeiros destinados ao } \\
\text { PACS / PSF }\end{array}$ & 7 & $5,26 \%$ \\
\hline $\begin{array}{l}\text { Rede de saúde inadequadamente articulada para implementar a estratégia } \\
\text { de atuação do PSF }\end{array}$ & 7 & $5,26 \%$ \\
\hline Outros & 5 & $3,76 \%$ \\
\hline Ausência / Insuficiência de veículos para locomoção das equipes PSF & 4 & $3,01 \%$ \\
\hline $\begin{array}{l}\text { Impossibilidade / Ausência de comprovação das despesas realizadas a } \\
\text { partir de recursos da conta PSF }\end{array}$ & 4 & $3,01 \%$ \\
\hline ACS contratados não residem nas comunidades em que atendem & 2 & $1,50 \%$ \\
\hline
\end{tabular}


Tabela 3.4. Irregularidades no âmbito do PAB - Fixo / Atendimento Assistencial Básico nos Municípios Brasileiros

\begin{tabular}{|c|c|c|}
\hline Irregularidade & Qtde & Incidência \\
\hline $\begin{array}{l}\text { Irregularidades referentes aos instrumentos básicos do sistema de } \\
\text { planejamento do SUS }\end{array}$ & 122 & $78,21 \%$ \\
\hline Desvio de finalidade na utilização de recursos do PAB & 72 & $46,15 \%$ \\
\hline $\begin{array}{l}\text { Irregularidades relativas à formação e/ou ao funcionamento do Conselho } \\
\text { Municipal de Saúde (CMS) }\end{array}$ & 72 & $46,15 \%$ \\
\hline $\begin{array}{l}\text { Falhas na gestão e operacionalização do Fundo Municipal de Saúde - } \\
\text { FMS }\end{array}$ & 45 & $28,85 \%$ \\
\hline Gerenciamento inadequado dos recursos financeiros e das contas do PAB & 41 & $26,28 \%$ \\
\hline $\begin{array}{l}\text { Documentação com elementos insuficientes para atestar a finalidade de } \\
\text { uso de recursos do PAB / desorganização documental }\end{array}$ & 26 & $16,67 \%$ \\
\hline $\begin{array}{l}\text { Aquisição de bens ou contratação de serviços não foi estruturada de } \\
\text { acordo com a Lei de Licitações }\end{array}$ & 25 & $16,03 \%$ \\
\hline Impropriedades em processos licitatórios & 21 & $13,46 \%$ \\
\hline $\begin{array}{l}\text { Impropriedades detectadas no gerenciamento de bens móveis e serviços } \\
\text { realizados com recursos do PAB-fixo }\end{array}$ & 18 & $11,54 \%$ \\
\hline $\begin{array}{l}\text { Licitação na modalidade convite com número de propostas válidas } \\
\text { inferior a três }\end{array}$ & 14 & $8,97 \%$ \\
\hline $\begin{array}{l}\text { Irregularidades na contratação de profissionais e/ou de instituições } \\
\text { privadas responsáveis pela execução de serviços básicos de saúde }\end{array}$ & 12 & $7,69 \%$ \\
\hline Restrição à competitividade em certame licitatório & 10 & $6,41 \%$ \\
\hline Outros & 8 & $5,13 \%$ \\
\hline $\begin{array}{l}\text { Monitoramento deficiente dos profissionais e das entidades conveniadas } \\
\text { que atuam na atenção básica }\end{array}$ & 8 & $5,13 \%$ \\
\hline Indícios de fraude em processos licitatórios & 5 & $3,21 \%$ \\
\hline Insuficiência de medicamentos e/ou deficiência no controle e estocagem & 4 & $2,56 \%$ \\
\hline $\begin{array}{l}\text { Pagamentos acima do estipulado em contrato / processo licitatório; } \\
\text { Pagamentos intempestivo }\end{array}$ & 3 & $1,92 \%$ \\
\hline Baixa resolubilidade do sistema de atenção básica à saúde no município & 2 & $1,28 \%$ \\
\hline $\begin{array}{l}\text { Cobrança de consultas básicas aos usuários do SUS por parte de entidade } \\
\text { conveniada }\end{array}$ & 1 & $0,64 \%$ \\
\hline
\end{tabular}

Fonte: Controladoria Geral da União 
Tabela 3.5. Irregularidades no âmbito da Estruturação da Rede de Serviços de Atenção Básica de Saúde

\begin{tabular}{lcc}
\hline \hline \multicolumn{1}{c}{ Irregularidade } & Qtde & Incidência \\
\hline $\begin{array}{l}\text { Descumprimento de exigências perante órgão concedente previstas em } \\
\text { contrato }\end{array}$ & 35 & $44,30 \%$ \\
$\begin{array}{l}\text { Irregularidades no gerenciamento dos bens adquiridos mediante convênio } \\
\text { com a União }\end{array}$ & 31 & $39,24 \%$ \\
$\begin{array}{l}\text { Impropriedades em processos licitatórios } \\
\text { Informações incompletas no preenchimento das notas fiscais, conforme }\end{array}$ & 29 & $36,71 \%$ \\
preceitua o art. 30 da IN/STN 01/97. & $29,11 \%$ \\
$\begin{array}{l}\text { Restrição à competitividade em certame licitatório } \\
\text { Licitação na modalidade convite com número de propostas válidas inferior a } \\
\text { três }\end{array}$ & 17 & $24,05 \%$ \\
$\begin{array}{l}\text { Outros } \\
\text { Aquisição de bens ou contratação de serviços não foi estruturada de acordo } \\
\text { com a Lei de Licitações }\end{array}$ & 13 & $13,52 \%$ \\
Documentação precária referente a convênio / licitação & $16,46 \%$ \\
Indícios de fraude em processos licitatórios & 13 & $16,46 \%$ \\
$\begin{array}{l}\text { Preços Unitários de itens contratados com valores acima aos de mercado / } \\
\text { superfaturamento }\end{array}$ & 11 & $13,92 \%$ \\
Atraso na execução do Plano de Trabalho / convênio & 6 & $7,59 \%$ \\
$\begin{array}{l}\text { Irregularidades na execução e pagamento de obras } \\
\text { Liberação de recursos antecipada / com o Plano de Trabalho incompleto }\end{array}$ & 4 & $5,06 \%$ \\
\hline \hline
\end{tabular}

Fonte: Controladoria Geral da União

A única irregularidade que é equanimente transversal aos três programas é a notificação inadequada da liberação de recursos pela prefeitura em dissonância ao exigido pela Lei 9.452/97, que estabelece que, ao receber recursos oriundos da União, o Poder Executivo Municipal beneficiário deve informar os partidos políticos, sindicatos profissionais e patronais com sede no município. A elevada incidência deste desvio (55,6\% dos municípios fiscalizados) é sintomática do reduzido grau de transparência na condução das políticas públicas executadas pelas prefeituras municipais. 


\subsection{Irregularidades no Programa de Saúde da Família}

No escopo do Programa Saúde da Família, a irregularidade com maior incidência foi o descumprimento da razão de famílias atendidas por cada profissional de saúde, detectado em 32,3\% dos municípios fiscalizados. A Portaria 648 / 2006 GM/MS estabelece que cada equipe multiprofissional seja responsável por, no máximo, 4.000 habitantes e que cada ACS cubra até 750 pessoas, pelo fato de que ser considerado este o limite superior até o qual os profissionais de saúde conseguem prestar um atendimento adequado para cada paciente. Equipes incompletas e a constatação de que funcionários das equipes de saúde estavam executando outras funções que não as previstas no programa ou atuando em mais de uma ESF também consistem em apontamentos realizados pelos auditores que implicam na mencionada falha. Receberam o mesmo tratamento pelo entendimento de que a falta de quantitativo em cada equipe gera a precariedade no atendimento que os limites impostos na mencionada norma visam evitar. A explicação padrão dos gestores municipais perante a constatação da irregularidade na fiscalização é que os municípios se defrontam com grande rotatividade de trabalhadores na atenção básica. O que pode ser inferido é que, por parte dos municípios, há gerenciamento inadequado do quantitativo de funcionários atuantes na atenção básica, devido à inexistência de servidores aptos para cobrir os afastamentos de membros da equipe do PSF. Entretanto, pode se atribuir também parcela de responsabilidade ao Ministério da Saúde, a quem cabe definir o modelo das políticas de saúde. Afinal, a estrutura do PSF não consegue reter os profissionais como necessário para a consecução dos seus objetivos.

Em seguida, a constatação de infra-estrutura deficiente nas unidades básicas de saúde e o monitoramento insuficiente das frequiências e ações dos profissionais de saúde empataram no segundo lugar do ranking de incidência das irregularidades $(28,57 \%)$.

Como infra-estrutura deficiente, entende-se inexistência ou precariedade de pelo menos algum dos itens que devem compor uma unidade básica de saúde (UBS): consultório médico; área de recepção; local para arquivos e registros; sala de vacina; sanitários; estoque dos insumos necessários para funcionamento da UBS; entre outros. Embora a categoria criada aglutine diversas intensidades do problema, desde municípios cujas unidades de saúde são extremamente precárias até aqueles em que foi constatada ausência de algum item previsto na Portaria 648/2006 ${ }^{60}$, o fato de as Unidades Básicas de Saúde apresentarem condições

\footnotetext{
${ }^{60}$ A Portaria 648/2006 consolida a Política Nacional de Atenção Básica e estabelece diretrizes e normas para o funcionamento do PACS e do PSF. No item 3 de seu anexo, estão dispostos todos os itens que devem compor uma unidade básica de saúde.
} 
inadequadas consiste em falha que pode inviabilizar o atendimento adequado da população e, conseqüentemente, o alcance dos objetivos do programa.

Os desvios constatados pelos auditores que decorreram do controle incipiente das prefeituras acerca do trabalho executado pelos servidores foram caracterizados como monitoramento insuficiente das Equipes de Saúde da Família. O cumprimento de jornada de trabalho inferior a quarenta horas semanais, a realização de atendimentos em quantidade insuficiente e/ou sem qualidade foram agregadas nesta categoria pelo entendimento de que a falta de monitoramento permitiu que os profissionais de saúde se empenhassem precariamente na execução de suas atividades. A importância da dedicação exclusiva no Saúde de Família se deve ao fato de o programa propor criar um vínculo mais próximo do sistema de saúde com as comunidades atendidas, o que pode ser descaracterizado se os componentes das equipes de dedicarem a atividades alternativas. Embora em muitos municípios a ocorrência dessas irregularidades seja produto de gerenciamento frágil do sistema de saúde, houve agentes executores (prefeitos e secretários municipais de saúde) que admitiram, no espaço destinado nos relatórios de fiscalização a suas réplicas, que a leniência em relação ao fiel cumprimento da carga horária foi um subterfúgio encontrado para a atração de profissionais de saúde qualificados. O argumento é o de que o salário de reserva dos profissionais de saúde qualificados seria uma função crescente de três variáveis dos municípios: porte, nível de renda e distância dos principais centros urbanos. Ou seja, municípios pequenos, carentes e distantes dos grandes centros urbanos não conseguiriam pagar um salário suficiente para atrair médicos em dedicação exclusiva, portanto, permitem que os profissionais cumpram jornada de trabalho inferior à regulamentar para que possam complementar a renda com outras atividades de forma a contar com os respectivos profissionais no município.

Por sua vez, a inconsistência entre os dados constantes no SIAB e os obtidos fisicamente durante as fiscalizações foi constatada em $24,8 \%$ dos municípios. Foram encontradas divergências no cadastro de funcionários (em 15,04\% das localidades), na produção das ESF e nos dados dos pacientes $(13,53 \%)$ e no número de equipes de saúde existentes no município $(2,26 \%)^{61}$. O fornecimento de informações não fidedignas, além de limitar a capacidade gerencial do próprio município, impede que o principal financiador da atenção básica - a União - tenha acesso à real situação do sistema de saúde na localidade. No caso da divergência ocorrer em relação ao número de ESF atuantes, pode constituir-se falha

\footnotetext{
${ }^{61}$ A soma das partes é maior que $24,8 \%$ porque há municípios em que se constatou divergência em mais de um dos aspectos considerados.
} 
de maior gravidade quando o município declara haver quantidade superior de equipes do que há efetivamente, já que o financiamento do MS é proporcional ao número de ESF formadas. Este fato correu em uma apenas uma localidade. Vale frisar ainda que a confiabilidade dos resultados econométricos obtidos no capítulo anterior depende da qualidade das informações do SIAB. Portanto, ainda que exerça um papel importante para o gerenciamento e avaliação das políticas de atenção primária, os resultados dele extraídos devem ser avaliados com a devida cautela ${ }^{62}$.

O quinto desvio com maior incidência $(21,05 \%)$ no escopo do PSF dentre os municípios avaliados refere-se à contratação irregular de profissionais e constituição inadequada das equipes de saúde. No caso de constituição das equipes, a irregularidade consiste na remuneração, com recursos da parte variável do $\mathrm{PAB}$, de profissionais que a legislação ${ }^{63}$ não prevê como integrantes das equipes de saúde, tais como coordenadores, supervisores, técnicos administrativos, entre outros.

A forma de contratação de profissionais, por sua vez, abrange um espectro tão dilatado de situações quão polêmico é o modelo a ser adotado ${ }^{64}$. O Ministério da Saúde, assim como a Justiça do Trabalho, entende que a contratação de agentes comunitários e demais profissionais atuantes na atenção básica pode ocorrer através de duas maneiras: a contratação direta pelo regime CLT, por concurso público, ou contratação indireta ${ }^{65}$, mediante termo de parceria firmado com OSCIP ou contrato de gestão com Organização Social com experiência na área de saúde. ${ }^{66}$ Embora sob uma análise microeconômica estática, poder-se-ia obter níveis de bem-estar superiores por parte dos munícipes com a adoção de um sistema que incentivasse a concorrência via preços entre prestadores de serviços de saúde, pode-se argumentar que a contratação por concurso e a formalização como servidor público são elementos importantes para o êxito do programa, já que este modelo garante maior isonomia na contratação e estabilidade das políticas institucionais. Afinal, uma relativa estabilidade no quadro funcional é importante em qualquer organização para a consecução de suas metas, uma vez que parte

\footnotetext{
${ }^{62}$ Para uma descrição mais detalhada do modus operandi do SIAB e de suas limitações, vide Azevedo, Nunes e Pessoa (2007).

${ }^{63}$ Portarias GM/MS 1.886/1997 e 648/2006.

${ }^{64}$ Existe uma literatura de extensão considerável a tratar do tema (Nogueira, 1996; Nogueira, Silva e Ramos, 2000; Ministério da Saúde, 2002) que, no entanto, não será aqui explorada com base no julgamento de que seria necessária uma pesquisa a parte para abordar o tema de forma completa.

${ }^{65}$ Em 6,02\% dos municípios auditados, foi constatada a presença de contratação irregular de organização executora do programa, o que abarca desde a organização executora não se enquadrar juridicamente nas exigências da legislação, irregularidades na documentação referente ao convênio com a entidade contratada e até a inobservância do princípio de segregação de funções (gestor municipal de saúde era também gestor da contratada).

${ }^{66}$ Vide Lei 9.637/98, Lei 9.790/99 e Ministério da Saúde, 2002.
} 
considerável das ações efetuadas é realizada com base em conhecimento especializado e tácito $^{67}$.

A fiscalização da CGU, todavia, verificou a presença de várias formas de contratação de profissionais não aderentes a essas diretrizes: informalidade absoluta, realização de licitação entre profissionais como prestadores de serviços, cargos comissionados ou estatutários, contrato por tempo determinado, entre outros. Não obstante a necessidade das garantias básicas ao trabalhador em saúde e de vínculos institucionais entre o ente e seus funcionários, há de se reconhecer as dificuldades com que se deparam as prefeituras para a atração e manutenção de profissionais, sobretudo médicos, na atenção básica. Os salários que as prefeituras ofereciam, mesmo considerando o subsídio fornecido pelo governo federal, geralmente situavam-se abaixo do salário-eficiência do trabalhador, o que engendra elevada rotatividade de mão-de-obra. Neste contexto, a continuidade das políticas exigiria agilidade na contratação para reposição de funcionários, o que seria incompatível com os controles políticos e burocráticos subjacentes aos concursos públicos. ${ }^{68}$

A capacitação deficiente dos profissionais de saúde, por sua vez, desponta como irregularidade incidente em 18,8\% das localidades auditadas. A Portaria 648 / 2006 GM/MS estabelece que é de responsabilidade conjunta das secretarias estadual e municipal de saúde prover capacitação permanente para os profissionais integrantes das $\mathrm{ESF}^{69}$. O treinamento é imprescindível na medida em que o programa possui especificidades que o diferencia das políticas tradicionais e, principalmente, pelo fato de que os agentes comunitários, via de regra, não dispõem de qualquer treinamento em saúde quando contratados. Logo, a capacitação é condição sine qua non para que os agentes realizem as funções que lhes foram delegadas.

A Portaria 648 elenca também as ações em saúde que devem ser executadas pelas ESF, como visitas domiciliares, marcação de consultas prévias, cumprimento dos horários agendados e realização de reuniões para orientação quanto aos cuidados com a saúde. A execução deficiente destas ações foi constatada em 15,04\% dos municípios, o que explicita a pouca aderência dos profissionais envolvidos na atenção básica aos princípios do programa do qual são integrantes.

\footnotetext{
${ }^{67}$ Vide Nelson \& Winter, 1982.

${ }^{68}$ Nogueira, Silva e Ramos, 2000.

${ }^{69}$ Em municípios de até 100.000 habitantes, a responsabilidade pela capacitação é das secretarias estaduais de saúde, que deve provê-la em parceria com as respectivas prefeituras. No caso de localidades com população superior á 100.000 habitantes, as secretarias municipais são exclusivamente encarregadas de prover educação introdutória e continuadas às ESF.
} 


\subsection{Irregularidades no Programa de Atendimento Assistencial nos Municípios Brasileiros}

As irregularidades referentes aos instrumentos básicos de planejamento do sistema de atenção básica municipal consistiram na categoria com maior incidência no escopo dos programas considerados nesta pesquisa (78,21\%). Foram apontados neste item os municípios em que foram constatadas falhas associadas ao Plano Municipal de Saúde ou Relatório de Gestão, documentos estes que, conforme já discutido anteriormente, são necessários para habilitação dos municípios no SUS e conseqüente recebimento de verbas. Dentre estas falhas, destacam-se: os documentos não foram apresentados aos auditores; apresentados, porém, sem as exigências previstas na legislação; não aprovados pelo CMS; ou aprovados fora do prazo legal. Vale destacar que estas são irregularidades com custo de detecção reduzido, uma vez que esses documentos deverem ser regular e obrigatoriamente enviados pelos municípios ao Ministério da Saúde. Ou seja, a ausência de punição ou sequer advertência aos municípios e gestores que incorreram nas falhas acima demonstra a reduzida preocupação do ministério com a fiscalização dos recursos por ele destinados aos municípios.

Em seguida a constatação de problemas nos instrumentos básicos de gestão da atenção básica, o desvio de finalidade dos recursos do PAB-Fixo consistiu na irregularidade com incidência mais elevada nos municípios da amostra (46,15\%). Os recursos destinados aos municípios através do PAB-Fixo têm destinação específica para atividades de saúde relacionadas à atenção primária, como contratação de profissionais de saúde lotadas nas UBS, compra de equipamentos e insumos e manutenção dos postos e unidades de saúde da família. É importante destacar que, dos municípios nos quais foi apontada a presença desta irregularidade, a maior parcela realizou despesas na própria área de saúde, mas de forma indevida, seja na realização da integralização da contrapartida municipal na atenção básica ou em atividades não caracterizadas como serviços de atenção primária, tais como consultas e exames definidos como de média ou alta complexidade. Ou seja, nestes casos não se trata de apropriação privada dos recursos públicos, mas de utilização em outros fins que não o previsto na legislação ${ }^{70}$.

Assim como o desvio de finalidade, as irregularidades referentes à formação e ao funcionamento do Conselho Municipal de Saúde (CMS) foram detectadas em 46,15\% das localidades fiscalizadas. O parágrafo abaixo sintetiza a composição e função da referida organização:

\footnotetext{
${ }^{70}$ No entanto, houve a constatação de um desvio grave em um único município, como o pagamento de veículo de propriedade de particulares com recursos do PAB.
} 
O Conselho de Saúde, em caráter permanente e deliberativo, órgão colegiado composto por representantes do governo, prestadores de serviço, profissionais de saúde e usuários, atua na formulação de estratégias e no controle da execução da política de saúde na instância correspondente, inclusive nos aspectos econômicos e financeiros, cujas decisões serão homologadas pelo chefe do poder legalmente constituído em cada esfera do governo. $^{71}$

A organização e o funcionamento dos conselhos de saúde são regidos pela Lei 8.142/1990 e pela Resolução 333/2003 do Conselho Nacional de Saúde. De acordo com essas normas, o CMS deve ser composto, de forma paritária, por representantes de usuários, trabalhadores de saúde e governo, de forma a garantir a participação da sociedade nas políticas de saúde. Sua existência é condição necessária para que o município se habilite a receber os recursos do Fundo Nacional de Saúde para cobertura das ações em saúde cuja execução é de responsabilidade dos municípios. As principais impropriedades encontradas referente à formação do CMS são: composição não respeita a paridade estabelecida pela legislação; não observância à resolução que determina que o Presidente do CMS deve ser eleito em reunião plenária, pelos membros do conselho; e ausência de Regimento Interno do conselho. No que concerne ao seu funcionamento, as irregularidades detectadas são: gestor da saúde atua de forma independente do CMS; as reuniões não ocorrem mensalmente; atas e relatórios emitidos pelo conselho não foram disponibilizados à CGU; ausência de participação na elaboração do orçamento anual e demais instrumentos de gestão da saúde municipal; e desconhecimento, pelo CMS, dos recursos financeiros disponibilizados e aplicados nas ações de saúde.

Para que qualquer município se habilite a receber recursos do PAB, também é preciso que seja instituído o Fundo Municipal de Saúde ${ }^{72}$, que consiste num instrumento legal, de natureza contábil, orçamentária e financeira, com a finalidade de desvincular os recursos destinados à saúde do sistema de caixa único do Tesouro, assegurando sua aplicação na destinação específica. Os fundos municipais devem ficar sob gestão dos secretários de saúde e fiscalização dos respectivos conselhos de saúde. Entretanto, em 28,85\% dos municípios auditados foi constatada alguma irregularidade na gestão ou operacionalização dos fundos municipais de saúde, tais como: inexistência jurídica do Fundo Municipal de Saúde; gestão do fundo realizada pelo prefeito; e conta corrente de titularidade da prefeitura (e não da SMS).

\footnotetext{
${ }^{71}$ Lei $8.142 / 1990$, art. $1^{\circ}, \S 2^{\circ}$.

${ }^{72}$ Lei $8.142 / 1990$, art. $4^{\circ}$, inc. I.
} 
O Fundo Municipal deve ser a unidade gestora das contas correntes vinculadas a cada um dos programas que recebem de outros entes recursos com destinação específica. Os recursos referentes a cada programa devem ser apartados dos demais, a partir da abertura de uma conta específica para cada, com o intuito de facilitar a verificação, por parte dos órgãos de fiscalização e do Conselho Municipal, se os recursos estão sendo devidamente aplicados nas ações previstas. Todavia, em 26,28\% dos municípios fiscalizados foi constatada alguma irregularidade concernente ao gerenciamento dos recursos financeiros e das contas do PAB. Foram consideradas dentre as irregularidades consideradas neste grupo: recursos referentes a vários programas são gerenciados por conta única, sem identificação de cada programa; movimentação na conta $\mathrm{PAB}$ de recursos não referentes à atenção básica; movimentação de recursos destinados à cobertura da atenção básica em contas que não compõem o FMS; devolução de cheques emitidos em nome do FMS; ausência de aplicação de saldo remanescente da conta corrente em depósitos de poupança ou fundos de investimento; e a utilização de recursos federais destinados a outros programas de saúde para a contrapartida municipal no atendimento básico ou de recursos do PAB para contrapartida em outros programas federais.

Ainda no que se refere à gestão financeira e contábil das contas do PAB, o Ministério da Saúde exige a apresentação de demonstrativos da movimentação de recursos em cada conta, quando solicitada pelos órgãos de controle ${ }^{73}$. Em 16,67\% dos municípios tal exigência não foi cumprida, seja devido ao extravio dos documentos, à desorganização dos documentos comprobatórios, ou ainda à especificação imprecisa nas notas de empenho do programa de atendimento básico de saúde ao qual a despesa se refere, o que impossibilita a conciliação dos extratos bancários com os gastos por programa.

Uma questão especialmente importante no poder público e, conseqüentemente, nos sistemas municipais de saúde, é o cumprimento dos ritos estabelecidos pela legislação para a contratação de compras, serviços e obras. A Constituição Federal estabelece em seu artigo 37 que a administração pública "obedecerá aos princípios de legalidade, impessoalidade, moralidade, publicidade e eficiência", ${ }^{74}$ e que, "ressalvados os casos especificados na legislação, as obras, serviços, compras e alienações serão contratados mediante processo de licitação pública que assegure igualdade de condições a todos os concorrentes"75. A Lei 8.666/1993 institui as normas gerais sobre licitações e contratos da Administração Pública

\footnotetext{
${ }^{73}$ Portaria 648/2006 GM/MS.

${ }^{74} \mathrm{CF}$ art. 37, caput.

${ }^{75} \mathrm{CF}$ art. 37, inc. XXI.
} 
Federal, Estadual e Municipal, com base no objetivo de garantir a seleção da proposta mais vantajosa para o ente contratante, observados o princípio da isonomia e o caráter competitivo do processo.

Durante a análise dos relatórios da CGU, pôde-se constatar grande variedade de irregularidades referentes à contratação de fornecedores e, neste trabalho, optou-se por sistematizar as informações com base nos seguintes critérios: natureza da irregularidade, nível de gravidade e incidência. $\mathrm{O}$ formato final das categorias referentes às irregularidades em processos licitatórios está disposto na tabela abaixo, que ainda informa a incidência de cada no âmbito do Programa de Atendimento Assistencial Básico nos Municípios Brasileiros. Vale destacar que este mesmo padrão foi adotado nos desvios correspondentes ao Programa de Estruturação da Atenção Básica de Saúde, cujo foco é justamente a construção e aquisição de equipamentos para viabilizar atendimento primário adequado, cujos resultados são apresentados mais adiante.

Tabela 3.6: Irregularidades referentes à Lei 8.666/1.993 - PAB-Fixo

\begin{tabular}{lc}
\hline \hline Irregularidade & Incidência \\
\hline Contratação não foi estruturada de acordo com a Lei de Licitações & $16,03 \%$ \\
Impropriedades em processos licitatórios & $13,46 \%$ \\
Licitação na modalidade convite com menos que três propostas válidas & $8,97 \%$ \\
Restrição à competitividade em certame licitatório & $6,41 \%$ \\
Indícios de fraude em processos licitatórios & $3,21 \%$ \\
\hline \hline
\end{tabular}

Em relação à natureza da irregularidade, a primeira das categorias disposta na tabela que se destaca das demais: nesta foram apontados os municípios que incorreram em falhas estruturais no processo de contratação de despesas, enquanto as seguintes se referem a irregularidades detectadas ao longo da licitação. Como falhas estruturais entende-se que não foram atendidas as exigências dispostas nos artigos 23 e 24 da lei supramencionada, que tratam, respectivamente, da modalidade de licitação como função da natureza da despesa e de seu respectivo valor, e dos casos em que a licitação é dispensável.

Para efeito das contratações passíveis de realização pelo sistema de atenção básica dos municípios, são três as modalidades de licitação existentes - convite, tomada de preços e concorrência - como se pode observar na citação abaixo.

Art. 23. As modalidades de licitação a que se referem os incisos I a III do artigo anterior serão determinadas em função dos seguintes limites, tendo em vista o valor estimado da contratação:

I - para obras e serviços de engenharia: 
a) convite - até $\mathrm{R} \$ 150.000,00$;

b) tomada de preços - até $\mathrm{R} \$ 1.500 .000,00$;

c) concorrência: acima de $\mathrm{R} \$ 1.500 .000,00$;

II - para compras e serviços não referidos no inciso anterior:

a) convite - até $\mathrm{R} \$ 80.000,00$;

b) tomada de preços - até $\mathrm{R} \$ 650.000,00$;

c) concorrência - acima de $\mathrm{R} \$ 650.000,00$.

A legislação admite ainda dispensa de licitação em contratações cujo valor não exceda determinado valor ${ }^{76}$, além de outros casos específicos que não se aplicam ao escopo deste trabalho $^{77}$. Em 16,03\% dos municípios fiscalizados, estas exigências não foram cumpridas adequadamente, seja pela inobservância da obrigação legal de $\operatorname{licitar}^{78}$, por falhas na documentação que suportaria a dispensa de licitação ${ }^{79}$, pelo fracionamento indevido de despesas ${ }^{80}$ e enquadramento inadequado da modalidade de licitação.

Três categorias de irregularidades foram criadas com base no nível de gravidade dos desvios constatados pelos fiscais ao longo das licitações, cujas incidências estão dispostas acima: impropriedades em processos licitatórios, restrição à competitividade em certame e indícios de fraude. A primeira abarca as irregularidades menos graves, ao passo que a última incorpora as mais críticas.

As menos graves - classificadas como impropriedades em processos licitatórios consistem em descumprimentos de exigências procedimentais estabelecidas na Lei 8.666/93, como: falta de numeração do processo e das folhas; descumprimento do prazo mínimo de cinco dias úteis entre a divulgação da licitação e a abertura do certame; certidão expedida pela empresa vencedora com data posterior à abertura das propostas; falta identificação de representante legal e assinatura de participante em certame licitatório. As falhas classificadas como restrição à competitividade representam aquelas cuja ocorrência podem - no julgamento do autor - apontar para a inobservância dos princípios de isonomia e primazia pelo caráter

\footnotetext{
${ }^{76} \mathrm{R} \$ 15.000$ para obras de engenharia e $\mathrm{R} \$ 8.000,00$ para demais itens.

${ }^{77}$ Vide Lei 8.666/1993, artigo 24.

${ }^{78}$ Ressalte-se que neste caso, grande parte das irregularidades constatadas tem como origem entes conveniados que, por serem privados, entendem que suas compras não necessitariam de processo licitatório, a despeito de serem realizadas com recursos federais, o que contraria norma da Secretaria do Tesouro Nacional.

${ }^{79}$ A realização de compras diretas, ou seja, com dispensa de licitação, requer documentação suportiva, tal como a realização de três orçamentos e pesquisa de preços de mercado.

${ }^{80} \mathrm{O}$ enquadramento inadequado é, via de regra, gerado pela prática indevida de fracionamento de despesas. Esta prática não atende aos princípios da eficiência, do planejamento e da economicidade que devem nortear a administração pública porque, ao fracionar as despesas, os gestores despendem esforços e recursos em sucessivas compras que poderiam ter sido planejadas anteriormente para serem realizadas de apenas uma vez. Além disso, os preços cobrados tendem a ser superiores, em virtude de não serem obtidos ganhos de escala nas transações.
} 
competitivo da licitação, com potencial de interferência no resultado do certame. Dentre os enquadrados neste item, estão os seguintes problemas: em licitação na modalidade Tomada de Preços, houve convite a número limitado de empresas; foi constatado direcionamento de escolha de marca em licitação; a publicação do processo licitatório foi deficiente; foram convidadas empresas com sócios em comum, embora ao menos uma das empresas convidadas tenha sócios diferentes; o descarte de proposta de participante mediante justificativa inadequada; e a realização de licitação do tipo menor preço global quando, no julgamento dos auditores da CGU, o objeto da contratação admitiria a licitação no regime de menor preço unitário, que ensejaria maior competição. A realização de licitação na modalidade convite com menos que três propostas válidas poderia ter sido incluída neste item, todavia, em função da elevada incidência deste desvio, decidiu-se apartá-la das demais irregularidades ${ }^{81}$. Aquelas irregularidades categorizadas como indícios de fraude consistem naquelas em que há presença de elementos que demonstram inequívoca má-fé no decorrer do processo licitatório. São exemplos de fraudes constatados pelos fiscais: em processo na modalidade convite, todas as empresas convocadas têm sócios em comum; as empresas contratadas são reconhecidamente inidôneas; constatou-se presença de diferença padronizada nos preços unitários dos itens apresentados pelos participantes da licitação, caracterizando conluio entre estes; propostas apresentadas pelos concorrentes possuem redação e formatação idênticas; e falsificação de assinaturas e documentos.

\subsection{Irregularidades no Programa de Estruturação da Rede de Serviços da Atenção Básica}

O programa de estruturação da rede de atenção básica consiste na execução de Programas de Trabalho celebrados mediante convênios entre os municípios e a União (eventualmente, os estados também participam) para a aquisição de equipamentos necessários para a execução do atendimento primário. Logo, o objeto do programa é a realização de licitações, fato pelo qual toda a discussão disposta acima acerca do descumprimento das exigências da Lei 8.666/1993 a ele se aplica integralmente. Desta forma, no que se refere às irregularidades já discutidas, porém cometidas no âmbito de programa de estruturação, apenas

\footnotetext{
${ }^{81}$ A elevada ocorrência desta irregularidade pode ser justificada pela redação da Lei 8.666/1993 e de sua interpretação pelos tribunais de contas. A lei dispõe que, no caso de licitação na modalidade convite, devem ser escolhidas e convidadas, no mínimo três empresas, porém, não restringe a continuidade do processo no caso de que um número inferior a três entregarem propostas válidas. É do entendimento do TCU (e, conseqüentemente, da CGU) que, no entanto, teria de ser repetido o convite até que o município lograsse obter três propostas válidas, interpretação esta que não era compartilhada pela maioria dos tribunais de contas dos quatro estados estudados, que legitimavam o procedimento adotado pelos prefeituras.
} 
disporemos os resultados na tabela abaixo. Como seria de se esperar, cada um dos cinco desvios discutidos tiveram incidência maior aqui.

Tabela 3.7: Irregularidades referentes à Lei 8.666/1993 - Estruturação da Rede de Serviços de Atenção Básica de Saúde

\begin{tabular}{lc}
\hline \hline Irregularidade & Incidência \\
\hline Impropriedades em processos licitatórios & $36,71 \%$ \\
Restrição à competitividade em certame licitatório & $24,05 \%$ \\
Licitação na modalidade convite com menos que três propostas válidas & $21,52 \%$ \\
Contratação não foi estruturada de acordo com a Lei de Licitações & $16,46 \%$ \\
Indícios de fraude em processos licitatórios & $13,92 \%$ \\
\hline
\end{tabular}

A Instrução Normativa STN 1/1997 é a principal norma a reger os convênios celebrados entre a União e os demais entes federativos, estabelecendo os procedimentos subjacentes, desde o credenciamento até a respectiva prestação de conta. Em 44,3\% dos municípios fiscalizados houve constatação de descumprimento das exigências previstas na referida norma perante o órgão concedente, o que representa a irregularidade com maior nível de incidência dentre no programa de estruturação da atenção básica de saúde. A alteração de objeto do convênio, sem retificação perante órgão concedente ${ }^{82}$; o emprego do objeto em desconformidade com previsto no Plano de Trabalho; a não disponibilização de contrapartida conforme estipula contrato ou convênio; irregularidades na aplicação financeira dos recursos mantidos em conta corrente ${ }^{83}$; e a não devolução de saldo de convênio remanescente para a Administração Federal $^{84}$ foram as irregularidades cometidas em desacordo com a IN STN $1 / 1997$.

Irregularidades no gerenciamento dos bens adquiridos através de convênio representaram a segunda falha mais freqüente, constatada em 39,24\% das localidades fiscalizadas. Como gerenciamento inadequado, foram considerados os seguintes fatos: os bens adquiridos ou equipamentos construídos com recursos de convênio não foram localizados e/ou estão sem utilização; unidades móveis de saúde estão sem utilização ou subutilizadas; constatada ausência de plaquetas de patrimônio em equipamentos hospitalares; controle

\footnotetext{
${ }^{82}$ A alteração de convênio, ou Plano de Trabalho, seja acerca do objeto adquirido ou do emprego ao qual este se destina, requer solicitação ao órgão concedente e sua posterior aprovação previamente à iniciação do certame licitatório, nos termos da IN 1-97 STN, art. 15.

${ }^{83} \mathrm{O}$ art. 20 da IN 1-97 STN estabelece as modalidades em que os recursos transferidos pela União para execução de convênios devem ser aplicados no mercado financeiro, enquanto não são destinados ao pagamento do objeto contratado. O mesmo explicita que os recursos apenas podem ser utilizados para a execução do convênio firmado.

${ }^{84}$ Os saldos financeiros remanescentes devem ser devolvidos à União (IN 1-97, art.22, § $6^{\circ}$ ).
} 
insuficiente da movimentação de veículos; e uso por entidades privadas de equipamento público adquirido com recursos do convênio. Interessante destacar que foi no âmbito do PABFixo esta irregularidade foi observada numa quantidade de substancialmente menor de municípios ${ }^{85}$.

Em seguida, pela ordenação das categorias de irregularidades com base em sua incidência, verifica-se a presença de duas irregularidades que, embora possam ser consideradas de caráter formal, sua incidência pode ser considerada indicador da fragilidade no gerenciamento do poder público municipal: o desacordo com o estabelecido pela legislação acerca do preenchimento das notas fiscais $^{86}(29,11 \%$ dos municípios $)$ e precariedade na documentação referente a convênio e licitação associada (16,46\%).

\footnotetext{
${ }^{85}$ A incidência da irregularidade nas ações associada ao PAB-Fixo foi de 11,54\%. Uma explicação potencial para tal constatação teria como base o fato de que, geralmente, é reduzida a contraparte dos municípios no financiamento dos convênios selados com o Ministério da Saúde no escopo da Atenção Básica. Conseqüentemente, haveria pouco incentivo por parte dos munícipes em fiscalizar o emprego desses recursos, já que o financiamento seria socializado com os contribuintes de todo o país.

${ }^{86}$ Vide o Anexo para descrição das exigências dispostas no art. 30 da IN/STN.
} 


\section{CONCLUSÃo}

Neste trabalho, procurou-se avaliar a política de atenção básica, em termos da eficácia e qualidade da gestão municipal nos quatro estados da Região Sudeste. A atenção básica tem no Programa Saúde da Família a estratégia prioritária para sua organização de acordo com os preceitos do SUS. No modelo estabelecido, à União compete estabelecer as diretrizes nacionais e financiar (parcialmente) os municípios, que são os entes responsáveis pela organização e execução das ações previstas.

A análise da eficácia foi realizada a partir da estimação do efeito parcial da cobertura populacional do PSF e PACS sobre os indicadores de saúde municipais, com base em um painel de municípios. A partir da referida estratégia de estimação, este trabalho confirmou o resultado de Serra (2003) acerca do impacto positivo do Programa de Saúde da Família sobre a mortalidade infantil, embora as magnitudes estimadas sejam distintas. Para os municípios paulistas entre 1998 e 2001, Serra estimou um declínio médio de, respectivamente, quatro e dez óbitos infantis (para cada mil nascidos vivos) com a implantação plena do PSF e do PACS. Para os municípios de toda a Região Sudeste entre 1999 e 2003, por sua vez, estimamos um impacto menos intenso sobre a mortalidade infantil: redução de 2,46 óbitos com o PSF (diferente de zero a 5\% de significância) e estatisticamente igual a zero com o PACS. Considerando-se que, no ano de 1999, a taxa de mortalidade infantil média nos municípios com mais de 50.000 habitantes era de 19,6 por mil nascidos vivos, não seria equivocado afirmar que o Programa de Saúde da Família foi eficaz no objetivo de reduzir os óbitos infantis, uma vez que, de acordo com os resultados obtidos, foi responsável por reduzir a taxa de mortalidade em $12,6 \%{ }^{87}$.

Além disso, as estimações realizadas com o índice de anos de vida perdidos como variável dependente geraram a percepção que as ações de atenção básica territorialmente adstritas reduzem consideravelmente a subnotificação de óbitos, o que implica em maior confiabilidade das bases de dados utilizadas pelos pesquisadores da área de saúde e tomadores de decisão de políticas de saúde pública. A elevação do grau de confiabilidade das bases de dados do SUS (DATASUS) é um mérito per se, afinal, tornam mais precisas as avaliações de políticas e possibilitam que os órgãos de saúde dos três níveis de governo realizem

\footnotetext{
${ }^{87}$ Ao contrário de Serra (2003), não foi estimada a especificação para cálculo das elasticidades, em função de mais da metade dos municípios não terem cobertura do PACS e PSF em algum ano, o que implica em exclusão da observação da amostra, uma vez que o logaritmo de zero não existe.
} 
diagnósticos mais precisos acerca das principais carências, problemas e experiências bem sucedidas na atenção à saúde e, conseqüentemente, utilizem os recursos de que dispõem de forma mais eficaz e eficiente.

A análise do aspecto da morbidade, com base nas internações hospitalares pagas pelo SUS, indica que a redução das internações a partir do crescimento da cobertura da atenção básica é função da existência ou não de um hospital no próprio município. Nos municípios sem atendimento hospitalar próprio, há redução significativa da quantidade de internações e no correspondente dispêndio para seu pagamento, e o contrário ocorre nas localidades dotadas de hospitais. Este resultado sugere uma diferença no modus operandi dos sistemas municipais que seria determinada pela variável presença de hospital. Ou seja, naqueles locais em que não há hospitais, deve haver maior freqüência de demandas sanadas nas próprias unidades básicas de saúde ou ainda maior incidência de casos em que, mesmo após o diagnóstico realizado nas UBS, permanecem pendentes de tratamento. Uma explicação relativamente intuitiva seria haver mais resistência, por parte dos usuários, médicos e gestores de saúde, em relações aos encaminhamentos a outros municípios. Os próprios pacientes podem hesitar em realizar o tratamento indicado, dado o maior tempo necessário distante de atividades produtivas ou devido à distância da família. Os médicos e gestores podem preferir não encaminhar os pacientes para outros municípios devido, respectivamente, à maior dificuldade em acompanhar o tratamento do paciente, assim em função do crescimento expressivo de custos com a locomoção a outras cidades e pagamento de serviços a prestadores fora do sistema municipal. Entretanto, não podemos afirmar categoricamente que estas sejam as razões para o fato constatado.

No que concerne aos aspectos institucionais do programa, o modelo adotado para a implantação do sistema de atenção básica tem como objetivo fornecer os incentivos necessários para que os sistemas municipais de atendimento primário se estabeleçam como base estruturante do Sistema Único de Saúde, de acordo com os princípios de universalidade, descentralização e participação social, com o menor custo médio possível. Nesse sentido, o Piso da Atenção Básica e os convênios celebrados consistem em subsídios que fomentam o fornecimento, por parte dos municípios, dos serviços básicos de saúde, caracterizados por gerar uma expressiva gama de externalidades positivas. O Ministério da Saúde centraliza as funções de normalização e coordenação do SUS, define seus parâmetros gerais, dota os sistemas municipais e estaduais de capacidade gerencial e absorve informações acerca das experiências de execução descentralizadas de políticas, com vistas a tornar o sistema mais eficaz, mais eficiente e menos oneroso. Afinal, se as políticas fossem adotadas de forma 
totalmente atomizada, sem qualquer intercâmbio de experiências entre os agentes executores, cada município ajustaria seus programas exclusivamente através de processo individual de tentativa e erro. Incorrer-se-ia em custos desnecessários, ao desperdiçar uma das principais vantagens de um sistema federativo, que é a relativa maior fluidez de informações e de experiências de gestão. Portanto, no que se refere ao desenho do sistema de atenção básica de saúde, pode se afirmar que este apresenta racionalidade econômica e possui diversos pontos positivos.

Porém, com base nos resultados gerados a partir do esforço de sistematização das irregularidades na execução na administração municipal das políticas de atenção básica, podese constatar que há problemas críticos na execução do modelo, alguns dos quais favorecidos pelo modelo do programa. Uma questão crítica da atenção básica, que perpassa muitas das categorias de irregularidades acima, consiste em que o modelo de financiamento da política é altamente dependente de recursos federais, o que gera desincentivo de que as populações beneficiárias fiscalizem adequadamente a aplicação dos recursos. Afinal, com a socialização com todos os contribuintes do país dos custos subjacentes à política de saúde, os munícipes não internalizam a análise de seu custo-benefício e podem ser mais relaxados na cobrança em relação ao poder público municipal. Mesmo na presença de instrumentos que dotem de relativa transparência as contas governamentais e correspondentes aplicações de recursos, situação esta em que poucos municípios se enquadram, o exercício de diluição da assimetria de informações entre população e policy-makers exige um nível considerável de esforço por parte dos primeiros. No caso do município brasileiro médio, com exígua disponibilidade de informações, então, o monitoramento dos recursos disponíveis e das aplicações realizadas transforma-se em trabalho hercúleo que dificilmente compensará o reduzido custo marginal incidente sobre cada munícipe para o financiamento de equipes de saúde adicionais ou demais equipamentos médicos.

Entretanto, há elementos que devem ser mitigadores do problema do gerenciamento frágil das políticas descentralizadas: presença de fiscalização mais intensa, punições mais rígidas e céleres para os indivíduos comprovadamente envolvidos em desvios e maior transparência na gestão municipal.

Um argumento que ilustra o controle frágil do programa por parte do Ministério da Saúde, pelo menos anteriormente ao período das fiscalizações da CGU consideradas neste trabalho, é a elevada incidência de irregularidades nos instrumentos básicos do sistema de planejamento do SUS, como o Plano Municipal de Saúde e Relatório de Gestão. Esses documentos devem ser regular e obrigatoriamente enviados pelos municípios ao Ministério da 
Saúde, portanto, o fato de a CGU ter apontado falhas em quase $80 \%$ dos municípios auditados, combinada à ausência de punição ou sequer advertência aos municípios e gestores, demonstra a reduzida preocupação do ministério com a fiscalização dos recursos por ele destinados aos municípios. A atuação da Controladoria Geral da União, todavia, através do programa de fiscalização a partir de sorteios públicos e de outros mecanismos, fiscalizando o emprego dos recursos federais dos programas de execução descentralizada, converge com a demanda de se intensificar a fiscalização sobre a utilização dos recursos públicos e consiste em importante fator limitante de impropriedades. Ainda assim, o efeito das fiscalizações é reduzido na ausência de punição para os indivíduos envolvidos nas irregularidades detectadas, sobretudo em relação àquelas referentes a fraudes, desvios de recursos e prevaricação, em que há ganhos pecuniários individuais. Afinal, de acordo com a literatura econômica, a decisão acerca de cometer um crime, por parte de um indivíduo hedonista, é função exclusiva dos benefícios gerados pelo ilícito, da probabilidade de ser descoberto e a conseqüente punição ${ }^{88}$.

A disponibilização para o público dos dados referentes aos gastos realizados pelos municípios, preferivelmente a partir de relatórios gerenciais informatizados, com diferentes níveis de agregação, reduziria substancialmente os custos associados ao levantamento das informações pelos eleitores. Portanto, vincular as transferências intergovernamentais à disponibilização destas informações na internet poderia ser uma medida com potencial de redução significativa dos desvios cometidos pelos gestores municipais. Em suma, transparência, fiscalização e punição são três fatores que possibilitariam melhorar a gestão dos recursos da política de atenção básica sem grandes alterações na sua estrutura.

Outra questão que deriva da dependência de transferências da União para financiamento é a falta de autonomia dos municípios para adaptar o programa às especificidades locais e temporais. O fato de o Ministério da Saúde ser o financiador majoritário da estratégia de atenção básica torna crível a homogeneização das políticas executadas nos entes subnacionais, além de facilitar o controle (por parte da União) sobre o uso dos recursos e, por conseguinte, restringir o espaço para desvios cometidos durante sua execução. Todavia, há um trade-off latente entre maior controle pelo financiador e adaptabilidade a dificuldades não previstas ao longo da execução do programa. Dois exemplos ilustram esse argumento. O primeiro refere-se ao fato de o salário de reserva de um médico em localidades muito distantes de capitais ou centros regionais relevantes situar-se, geralmente, acima da capacidade de pagamento destes. Frente à dificuldade para importar

\footnotetext{
${ }^{88}$ Vide Becker, 1968.
} 
médicos, há gestores que realizam um acordo tácito com os profissionais: não controlam os horários de trabalho, de forma que os médicos tenham jornada de trabalho inferior à estabelecida pelo MS e possam complementar a renda com atendimentos particulares ou trabalhando para outro município próximo. A prática de permitir a jornada de trabalho inferior à regulamentar é uma fraude, porém viabiliza que os municípios contem com médico de família. Um segundo exemplo seria a necessidade de os recursos de cada programa serem geridos em contas correntes separadas, de forma a facilitar o controle sobre a utilização dos recursos. Embora o argumento de facilitar o controle seja razoável, essa prática incorre em dois tipos de custos para os municípios: o trabalho adicional necessário para o gerenciamento de várias contas e o custo de oportunidade associado à limitação das aplicações financeiras disponíveis decorrente da redução do saldo disponível em cada conta corrente ${ }^{89}$.

A ampliação da autonomia dos municípios, no entanto, dificilmente viria sem o aumento da capacidade de financiamento com recursos próprios, o que requereria alterações na estrutura tributária nacional, assunto além do escopo da política de atenção básica de saúde. Ainda que desejável do ponto de vista dos incentivos gerados na execução de programas descentralizados, um crescimento da participação dos municípios na arrecadação total provocaria efeitos indesejados do ponto de vista distributivo, ou seja, há presença de trade-off entre eficiência e distribuição.

Em suma, nos seus aspectos gerais, o modelo adotado na política de atenção básica apresenta racionalidade econômica e apresenta fundamento na teoria de federalismo fiscal. Em termos de eficácia perante a melhora dos indicadores municipais de saúde, foi constatada redução significativa na mortalidade infantil e melhora no apontamento de óbitos (ou redução da subnotificação). Porém, verificou-se que o programa não causa redução das internações hospitalares. No que se refere à gestão da política, a diversidade e frequiência das irregularidades encontradas encontram-se muito acima de um patamar razoável. Ainda que a eficiência no emprego de recursos, no significado estrito do termo, não tenha sido calculada, a análise das irregularidades indica ser consideravelmente ineficiente a utilização dos recursos pelos municípios, seja em função de má-gestão ou desvio. Ou seja, há muito espaço para melhorar. Com base nos pontos discutidos ao longo deste trabalho, podemos apontar algumas medidas que poderiam ter um papel importante na melhora da execução da atenção básica. Em primeiro lugar, condicionar a liberação de recursos ao incremento da transparência das

\footnotetext{
${ }^{89}$ Como a taxa de administração dos fundos de investimento é inversamente proporcional à aplicação mínima vinculada a cada conta corrente, com a redução do saldo em cada conta, há redução dos rendimentos obtidos com as aplicações financeiras.
} 
contas dos municípios, de forma a incentivar maior participação da população na fiscalização do emprego dos recursos públicos. Além disso, seria desejável permitir um incremento marginal na autonomia dos municípios no que se refere à utilização de recursos federais, de forma que os gestores municipais pudessem adequar os instrumentos de gestão às especificidades e limitações locais. E, principalmente, punir adequadamente gestores, servidores e demais indivíduos envolvidos em irregularidades graves. 


\section{REFERÊNCIAS}

ALESINA, Alberto; PEROTTI, Roberto. Fiscal Discipline and the Budget Process. The American Economic Review, v.86. n. 02, p. 401-407, 1996.

ANDRADE, Mônica V.; LISBOA, Marcos. A economia da saúde no Brasil. In: LISBOA; Marcos, MENEZES-FILHO, Naércio A. (orgs.). Microeconomia e sociedade no Brasil. Rio de Janeiro: Contra Capa, p. 285-332, 2001a.

ANDRADE, Mônica V.; LISBOA, Marcos. Mortalidade nos Estados do Rio de Janeiro, São Paulo e Minas Gerais. Estudos Econômicos, vol. 31, n.1. São Paulo, 2001 b.

AZEVEDO, João P.; NUNES, Pedro; PESSOA, Marcelo. Análise da demanda do programa Brasil Alfabetizado a partir dos dados coletados pela pesquisa de Avaliação do Programa Bolsa Família e do Sistema de Informação de Atenção Básica de Saúde. Mimeo, 2007.

BARRETO, Maurício L.; CARMO, Eduardo H. Mudanças em Padrões de Morbimortalidade: Conceitos e Métodos. In: MONTEIRO, C.A. (org.) Velhos e Novos Males da Saúde no Brasil: A Evolução do País e suas Doenças, pp.186-192, São Paulo: Editora Hucitec/Núcleo de Pesquisas Epidemiológicas em Nutrição e Saúde, Universidade de São Paulo, 2000.

BECKER, Gary. Crime and Punishment: An Economic Approach. Journal of Political Economy, vol. 76, nº 2, pp. 169-217. Mar., 1968.

BECKER, Gary; LEWIS, H. Gregg. On the Interaction between the Quantity and Quality of Children. Journal of Political Economy, v.81, n. 02, p. S279-S288, 1973.

BRASIL. Constituição Federativa do Brasil (1988).

BRASIL. Lei 8.080, de 19/09/1990.

BRASIL. Lei 8.142, de 28/12/1990.

BRASIL. Lei 8.666, de 21/06/1993.

BRASIL. Lei 9.452, de 20/03/1997.

BRASIL. Lei 9.637, de 15/10/1998.

BRASIL. Lei 9.790, de 23/09/1999.

BRASIL. Controladoria Geral da União. Disponível em http://www.cgu.gov.br. Acesso em 20/08/2008.

BRASIL. Ministério da Fazenda. Secretaria da Receita Federal. Carga Tributária no Brasil 2005. Brasília, 2006.

BRASIL. Ministério da Fazenda. Secretaria do Tesouro Nacional. Instrução Normativa 1, de 15/01/1997. 
BRASIL. Ministério da Fazenda. Secretaria do Tesouro Nacional. Finanças do Brasil FINBRA: Dados Contábeis dos Municípios. Disponível em http://www.tesouro.fazenda.gov.br. Acesso em 09/09/2008.

BRASIL. Ministério da Saúde. Norma Operacional Básica do Sistema Único de Saúde 01/1996. Brasília, 1996.

BRASIL. Ministério da Saúde. Conselho Nacional de Saúde. Resolução 333, de 4/11/2003. Brasília, 2003.

BRASIL. Ministério da Saúde. Fundação Oswaldo Cruz. Saúde da Família - Avaliação da Implementação em Dez Grandes Centros Urbanos. Brasília, 2005.

BRASIL. Ministério da Saúde. Gabinete do Ministro. Portaria 648, de 28/03/2006. Brasília, 2006.

BRASIL. Ministério da Saúde. Gabinete do Ministro. Portaria 650, de 28/03/2006. Brasília, 2006.

BRASIL. Ministério da Saúde. Gabinete do Ministro. Portaria 1.886, de 18/12/1997. Brasília, 2006.

BRASIL. Ministério da Saúde. Secretaria da Atenção Básica. Política Nacional de Atenção Básica. Brasília, 2006.

BRASIL. Ministério da Saúde. Secretaria de Assistência à Saúde. Coordenação de Atenção Básica. Avaliação da Implantação e Funcionamento do Programa de Saúde da Família PSF. Brasília, 1999.

BRASIL. Ministério da Saúde. Secretaria Executiva. Programa Saúde da Família. Brasília, 2001a.

BRASIL. Ministério da Saúde. Secretaria Executiva. Programa Agentes Comunitários de Saúde - PACS. Brasília, 2001b.

BRASIL. Ministério da Saúde. Secretaria de Políticas de Saúde. Departamento de Atenção Básica. Modalidade de Contratação de Agentes Comunitários de Saúde - Um Pacto Tripartite. Brasília, 2002.

FONSECA, Luiz Augusto M.; LAURENTI, Ruy. Evolução da mortalidade materna. In: MONTEIRO, C.A. (org.) Velhos e Novos Males da Saúde no Brasil: A Evolução do País e suas Doenças, pp.186-192, São Paulo: Editora Hucitec/Núcleo de Pesquisas Epidemiológicas em Nutrição e Saúde, Universidade de São Paulo, 2000.

FOURNIER, C. Panorama of evaluative studies: mortality indicators, data sources and methods of estimation. In: KHLAT, M. (ed.). Demographic Evaluation of Health Programmes. Paris, CICRED, p. 15-27, 1997.

GERTLER, P. The Impact of PROGRESA on Health. Washington D.C.: International Food Policy Research Institute, 2000. 
GIAMBIAGI, Fábio; ALÉM, Ana Cláudia. Finanças Públicas: Teoria e Prática No Brasil. $2^{a}$ Edição. Rio de Janeiro: Elsevier Editora, 2001.

GROSSMAN, Michael; JACOBOWITZ, Steven. Variations in infant mortality rates among counties of the United States: the roles of public policies and programs. Demography, v.18, n.04, p.695-713, 1981.

INSTITUTO BRASILEIRO DE GEOGRAFIA E ESTATÍSTICA (IBGE). Censo Demográfico. Rio de Janeiro, 2000.

KOPITS, George. Transparency in Government Operations. In: Transparency and Development in Latin America and the Caribbean. Interamerican Development Bank, 2000.

LAURENTI, Ruy; MELlO JORGE, Maria Helena P. de; LEBRÃO, Maria Lúcia; e GOTLIEB, Sabina L.D. Estatísticas de Saúde. $2^{\text {a }}$ edição. São Paulo, EPU, 1987.

MARINHO, Alexandre; FAÇANHA, Luís O. Programas Sociais: Efetividade, Eficiência e Eficácia como Dimensões Operacionais da Avaliação. IPEA - Texto para Discussão $n^{\circ}$ 787, 2001.

McCRONE, Paul. Understanding Health Economics: A Guide for Health Care Decision Makers. London: Open University Press, 1998.

MUSGRAVE, Richard A.; MUSGRAVE, Peggy B. Public Finance in Theory and Practice. 2nd edition. New York: McGraw-Hill Book Company, 1976.

NELSON, Richard R.; WINTER, Sidney, G. An Evolutionary Theory of Economic Change. Cambridge, Mass: The Belknap Press, 1982.

NOGUEIRA, Roberto P. Estabilidade e flexibilidade: tensão de base nas novas políticas de Recursos Humanos em saúde. Divulgação em saúde para debate, v. 14, p.18-22, 1996.

NOGUEIRA, Roberto P.; SILVA, Frederico B.; RAMOS, Zuleide V.O. A Vinculação Institucional de um Trabalhador sui generis - o Agente Comunitário de Saúde. IPEA Texto para discussão n ${ }^{\circ}$ 735. Rio de Janeiro, 2000.

OATES, Wallace E. An Essay on Fiscal Federalism. Journal of Economic Literature, Vol. 37, No. 3, pp. 1120-1149. Set., 1999.

OATES, Wallace E. Fiscal Federalism. New York: Harcourt Brace Jovanovich, 1972 apud OATES, Wallace E. An Essay on Fiscal Federalism. Journal of Economic Literature, Vol. 37, No. 3, pp. 1120-1149. Set., 1999.

PRITCHETT, Lant; SUMMERS, Lawrence H. Wealthier is Healthier. Journal of Human Resources, v. 31, n.04, p.841-868, 1996.

ROMEDER, J-M.; MCWHINNIE, J.R. Potential Years of Life Lost Between Ages 1 and 70: An Indicator of Premature Mortality for Health Planning. International Journal of Epidemiology, v. 6, p. 143-151, 1977.

ROMER, David. Advanced Macroeconomics. 2nd edition. New York: McGraw-Hill, 2001. 
ROSEN, Harvey S. Public Finance. 4th edition. Homewood, IL: Richard D. Irwin, 1995.

SANTERRE, Rexford E.; NEUN, Stephen P. Health economics: Theories, Insights, and Industry Studies.

SEN, Amartya K. Desenvolvimento como Liberdade. São Paulo: Companhia das Letras, 2000 .

SERRA, Rodrigo A. M. Uma Avaliação Empírica do impacto do Programa Saúde da Família sobre a Saúde Infantil no Estado de São Paulo. São Paulo, 2003. Dissertação (Mestrado em Economia) - Programa de Pós-Graduação em Economia, Faculdade de Economia, Administração e Contabilidade da Universidade de São Paulo.

TERRA, Valéria; MALIK, Ana Maria. Programa Médico de Família de Niterói. In: FUJIWARI, Luis M.; ALESSIO, Nelson L.N.; FARAH, Marta F.S. (orgs.). 20 Experiências de Gestão Pública e Cidadania. $1^{a}$ edição. São Paulo: Ed. FGV, 1998.

VIANA, Ana Luiza D.;DAL POZ, Mario Roberto. Reforma do Sistema de Saúde no Brasil e o Programa de Saúde da Família. Physis: Revista Saúde Coletiva, Rio de Janeiro, 15 (Suplemento): p.225- 264, 2005.

WOOLDRIDGE, Jeffrey M. Econometric Analysis of Cross Section and Panel Data. Cambridge, MA: MIT Press, 2002.

WORLD HEALTH ORGANIZATION (WHO). Department of Reproductive Health and Research. Maternal Mortality in 2000: estimates developed by WHO, UNICEF, UNFPA. Genebra, 2004. 


\section{ANEXO I - DESCRIC̃̃̃O DAS CATEGORIAS DE IRREGULARIDADES RELACIONADAS AOS Programas da ATENĊ̃̃o Básica de SAÚde}

\section{I.A. Programa Saúde da Família}

\begin{tabular}{|c|c|}
\hline idade & \\
\hline $\begin{array}{l}\text { Não é atendido o estabelecido } \\
\text { no desenho do programa da } \\
\text { razão de famílias atendidas } \\
\text { por ESF ou componentes }\end{array}$ & $\begin{array}{l}\text { Foram agrupadas nesta categoria as seguintes irregularidades: ESF ou } \\
\text { ACS responsáveis por número de famílias superior ao máximo estipulado } \\
\text { pela legislação; equipes PSF incompletas; e funcionário da equipe de } \\
\text { saúde da família em desvio de função ou atuante em mais de uma PSF. }\end{array}$ \\
\hline $\begin{array}{l}\text { Irregularidades na } \\
\text { contratação de profissionais } \\
\text { ou na constituição das ESF }\end{array}$ & $\begin{array}{l}\text { Neste item foram consideradas as irregularidades referentes à constituição } \\
\text { das equipes ou à contratação de profissionais. No que se refere à } \\
\text { constituição, as irregularidades são a execução do programa com equipe } \\
\text { de trabalho incompleta ou a contrataçãa de profissionais de categorias em } \\
\text { que a legislação não prevê como integrantes das ESF. Em relação à } \\
\text { contratação, destacam-se a presença de acordo informal de trabalho e a } \\
\text { utilizaçâo de funcionários estatutários ou comissionados nas equipes. }\end{array}$ \\
\hline $\begin{array}{l}\text { Ausência / Insuficiência de } \\
\text { veículos para locomoção das } \\
\text { equipes PSF }\end{array}$ & $\begin{array}{l}\text { O desenvolvimento das ações no } \\
\text { locomoção das equipes para as res } \\
\text { programa. Para as equipes em que o } \\
\text { configura com freqüência nas área } \\
\text { indispensável para a consecução dos }\end{array}$ \\
\hline $\begin{array}{lr}\text { Irregularidades } & \text { no } \\
\text { gerenciamento } & \text { er } \\
\text { medicamentos e materiais } & \text { para uso exclusivo das ESF }\end{array}$ & $\begin{array}{l}\text { ocagem de } \\
\text { ização dos } \\
\text { las. }\end{array}$ \\
\hline \begin{tabular}{llr|} 
Desvio de finalidade & na \\
aplicação & de recursos \\
financeiros & destinados ao \\
PACS / PSF & & \\
\end{tabular} & $\begin{array}{l}\text { 1- PSF em } \\
\text { ção. }\end{array}$ \\
\hline $\begin{array}{l}\text { ESF não dispõem de infra- } \\
\text { estrutura adequada para } \\
\text { execução de seus trabalhos }\end{array}$ & $\begin{array}{l}\text { S os municípios cujas UBSs não cumpriram integralmente } \\
\text { m } 3 \text { do Anexo da Portaria } 648 \text { / } 2006 \text { GM/MS, que elenca } \\
\text { le devem compor uma unidade básica de saúde (UBS), de } \\
\text { a sejam realizadas adequadamente as ações de atenção } \\
\text { ípio. }\end{array}$ \\
\hline $\begin{array}{l}\text { Impossibilidade } \\
\text { comprovação das despesas } \\
\text { realizadas a partir de } \\
\text { recursos da conta PSF }\end{array}$ & $\begin{array}{l}\text { çumentação apresentada aos fiscais não fornece informações } \\
\text { ficientes para atesto da devida realização de despesas no âmbito do PSF. }\end{array}$ \\
\hline $\begin{array}{l}\text { Inconsistência nos dados do } \\
\text { SIAB }\end{array}$ & $\begin{array}{l}\text { S detectaram inconsistência entre os dados constantes no SIAB e } \\
\text { s "in loco", sejam referentes à produção das ESF, dos dados dos } \\
\text {, cadastro de funcionários e/ou número de equipes atuantes no } \\
\text { o. }\end{array}$ \\
\hline $\begin{array}{l}\text { Ações previstas no desenho } \\
\text { do programas não são } \\
\text { executadas adequadamente } \\
\text { no município }\end{array}$ & $\begin{array}{l}\text { Foram agregadas nesta categoria as irregularidades concernentes à } \\
\text { execução deficiente das ações previstas na Política Nacional de Atenção } \\
\text { Básica. Dentre elas, destacam-se: ausência de marcação de consultas } \\
\text { prévias; presença de filas para atendimento e/ou não cumprimento dos } \\
\text { horários agendados; ausência de reuniões para orientação quanto aos } \\
\text { cuidados com a saúde; descontinuidade na execução do programa; e a } \\
\text { manutenção de práticas curativas e reativas. }\end{array}$ \\
\hline $\begin{array}{l}\text { Monitoramento insuficiente } \\
\text { das Equipes de Saúde da } \\
\text { Família }\end{array}$ & $\begin{array}{l}\text { Não há monitoramento adequado sobre a frequiência ou produção dos } \\
\text { funcionários das equipes. Foram apontados neste item os municípios em } \\
\text { que foi constatado: (i) o descumprimento da jornada mínima de trabalho } \\
\text { de } 40 \text { horas semanais, conforme estabelecido na legislação; (ii) em que se } \\
\text { detectou níveis de produção insatisfatórios das equipes; ou (iii) qualidade } \\
\text { deficiente na produção das equipes. }\end{array}$ \\
\hline
\end{tabular}




\begin{tabular}{|c|c|}
\hline Irregularidade & Descrição e Justificativa \\
\hline 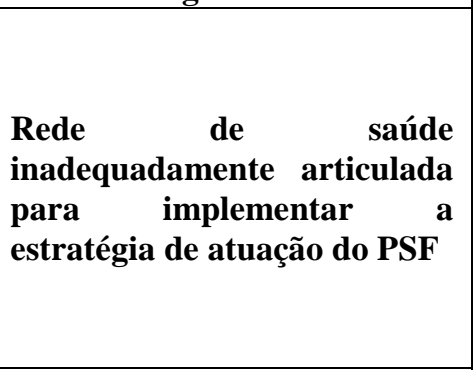 & $\begin{array}{l}\text { Articulação insuficiente entre os serviços de baixa complexidade e os de } \\
\text { média e alta. Estão abarcados neste item os municípios: (i) cujos cidadãos } \\
\text { não têm acesso a serviços de média ou alta complexidade de forma } \\
\text { satisfatória; (ii) não dispõem de prontuários, de forma que há precariedade } \\
\text { no acompanhamento do histórico dos pacientes; (iii) há ausência do } \\
\text { documento de contra-referência em poder dos clientes do PSF, de forma } \\
\text { que as UBS desconhecem o tratamento dispensado nas unidades de maior } \\
\text { complexidade; e (iv) há atraso excessivo na entrega de exames } \\
\text { laboratoriais prescritos nas UBS. }\end{array}$ \\
\hline $\begin{array}{lrr}\text { Contratação } & \text { irregular } & \text { de } \\
\text { organização } & \text { executora } & \text { do } \\
\text { programa } & & \end{array}$ & $\begin{array}{l}\text { Foram agregadas nesta categoria as irregularidades apontadas pelos fiscais } \\
\text { em relação à contratação de organizações para execução do PSF. São elas: } \\
\text { organização executora não permitida pela legislação; irregularidades na } \\
\text { documentação referente ao convênio com entidade contratada para } \\
\text { execução do programa; e inobservância do princípio de segregação de } \\
\text { funções na delegação }\end{array}$ \\
\hline $\begin{array}{l}\text { ACS contratados não residem } \\
\text { nas comunidades em que } \\
\text { atendem }\end{array}$ & $\begin{array}{l}\text { Um dos pilares do PSF é o estabelecimento de vínculo entre as famílias e } \\
\text { o sistema de saúde mediante o trabalho dos agentes comunitários. Se o } \\
\text { ACS não reside na comunidade em que trabalha, o programa perde o } \\
\text { poder de penetração nas localidades atendidas, um de seus elementos mais } \\
\text { importantes. }\end{array}$ \\
\hline $\begin{array}{l}\text { Capacitação inexistente ou } \\
\text { insuficiente para ACS e } \\
\text { demais integrantes das ESF } \\
\text { contratados }\end{array}$ & $\begin{array}{l}\text { A Portaria } 648 \text { / } 2006 \mathrm{GM} / \mathrm{MS} \text { estabelece que é de responsabilidade } \\
\text { conjunta das secretarias estadual e municipal de saúde prover capacitação } \\
\text { permanentes para os profissionais integrantes das ESF. O treinamento é } \\
\text { imprescindível na medida em que o programa possui especificidades que } \\
\text { o diferencia das políticas tradicionais e, principalmente, pelo fato de que } \\
\text { os agentes comunitários, via de regra, não dispõem de qualquer } \\
\text { treinamento em saúde quando contratados. }\end{array}$ \\
\hline $\begin{array}{l}\text { Planejamento deficiente para } \\
\text { implantação, execução e } \\
\text { expansão do PSF }\end{array}$ & $\begin{array}{l}\text { Extravio dos documentos referentes à organização e prestação de contas } \\
\text { do PSF; definição precária dos territórios abarcados pelo PSF, de forma } \\
\text { que os moradores de áreas mais carentes do município permanecem } \\
\text { desatendidos. }\end{array}$ \\
\hline Outros & $\begin{array}{l}\text { Foram agregadas aqui as irregularidades com reduzida incidência na } \\
\text { amostra utilizada. São elas: impropriedades em processos licitatórios }{ }^{90} \text {, } \\
\text { contrapartida do Município no PSF não detalhada nos extratos bancários } \\
\text { ou não aportada; e atraso no pagamento de salários das equipes PSF ou de } \\
\text { tributos federais referentes ao programa. }\end{array}$ \\
\hline
\end{tabular}

\footnotetext{
${ }^{90}$ A descrição desta irregularidade consta nas partes B e C deste Anexo.
} 


\section{I.B. PAB - FiXo: AtendiMENTO ASSISTENCIAL BÁSICO NOS MUNiCíPIOS BraSILEIROS}

\begin{tabular}{|c|c|}
\hline Irregularidade & Descrição e Justificativa \\
\hline $\begin{array}{l}\text { Baixa resolubilidade do } \\
\text { sistema de atenção básica à } \\
\text { saúde no município }\end{array}$ & $\begin{array}{l}\text { Incorpora municípios em que a CGU considerou haver alta } \\
\text { representatividade dos gastos com manutenção de veículos e transporte de } \\
\text { pacientes em relação aos recursos transferidos pelo Governo Federal, } \\
\text { indicando deficiências no sistema de atenção básica à saúde no município. } \\
\text { Abrange ainda as cidades cujos munícipes foram atendidos em outras } \\
\text { localidades para procedimentos classificados no escopo da atenção básica. }\end{array}$ \\
\hline $\begin{array}{l}\text { Impropriedades detectadas } \\
\text { no gerenciamento dos bens e } \\
\text { serviços realizados com } \\
\text { recursos do PAB-Fixo }\end{array}$ & $\begin{array}{l}\text { Esta categoria incorpora as falhas nos procedimentos para a realização de } \\
\text { despesas e no gerenciamento dos bens e serviços empregados na estratégia } \\
\text { de atenção básica em saúde. Dentre estas, destacam-se: inexistência de } \\
\text { atesto, por servidor responsável, nas notas fiscais de recebimento da } \\
\text { mercadoria ou prestação dos serviços; realização de despesas sem prévio } \\
\text { empenho; ausência de segregação de funções na aquisição de } \\
\text { medicamentos (funcionário responsável pela contratação não deve ser a } \\
\text { mesma que faz o recebimento da mercadoria); controle insuficiente da } \\
\text { movimentação de veículos; impossibilidade de atesto dos serviços } \\
\text { realizados; controle precário do estoque de materiais para uso na atenção } \\
\text { básica; fornecimento de produtos e serviços diferente do contratado; } \\
\text { instalações inadequadas no pronto atendimento; e bens adquiridos } \\
\text { extraviados e/ou sem utilização. }\end{array}$ \\
\hline $\begin{array}{l}\text { Documentação } \quad \text { com } \\
\text { elementos insuficientes para } \\
\text { atestar a finalidade de uso de } \\
\text { recursos do PAB }\end{array}$ & $\begin{array}{l}\text { As seguintes irregularidades foram agregadas neste item: realização de } \\
\text { despesas sem os respectivos comprovantes; desorganização documental; } \\
\text { documentação comprobatória incompleta; formalização inadequada de } \\
\text { documentos contábeis e financeiros; notas de empenho não especificam o } \\
\text { programa de atendimento básico de saúde ao qual a despesa se refere. }\end{array}$ \\
\hline $\begin{array}{l}\text { Irregularidades na } \\
\text { contratação de profissionais } \\
\text { e/ou de instituições privadas } \\
\text { responsáveis pela execução de } \\
\text { serviços básicos de saúde }\end{array}$ & $\begin{array}{l}\text { Abrange municípios em que foi constatada irregularidade no contrato } \\
\text { estabelecido com prestadores de serviços e/ou na contratação de } \\
\text { profissionais para atuação na atenção básica à saúde. As principais são: } \\
\text { contrato com cláusulas irregulares; contrato com vigência vencida, mas } \\
\text { prestação dos serviços e conseqüente remuneração ainda em vigor; } \\
\text { ausência de contrato; ausência de lei que institua os cargos dos } \\
\text { profissionais; ausência de concurso público para a investidura no serviço } \\
\text { público; e contratação de prestadores de serviços pessoa física através de } \\
\text { processo licitatório (o que não encontra amparo legal). }\end{array}$ \\
\hline $\begin{array}{l}\text { Gerenciamento inadequado } \\
\text { dos recursos financeiros e das } \\
\text { contas do PAB }\end{array}$ & $\begin{array}{l}\text { Compõem este item aquelas irregularidades referentes ao gerenciamento } \\
\text { das contas correntes referentes ao PAB. São elas: recursos do PAB, } \\
\text { referentes a vários programas, são gerenciados por conta única, sem } \\
\text { identificação do que foi gasto em cada programa; movimentação na conta } \\
\text { PAB de recursos não referentes à atenção básica; movimentação de } \\
\text { recursos destinados à cobertura da atenção básica em contas que não } \\
\text { compõem o FMS; descontrole no saldo das contas correntes; utilização de } \\
\text { recursos federais destinados a outros programas de saúde para a } \\
\text { contrapartida municipal no atendimento básico ou de recursos do PAB } \\
\text { para contrapartida em outros programas federais }\end{array}$ \\
\hline 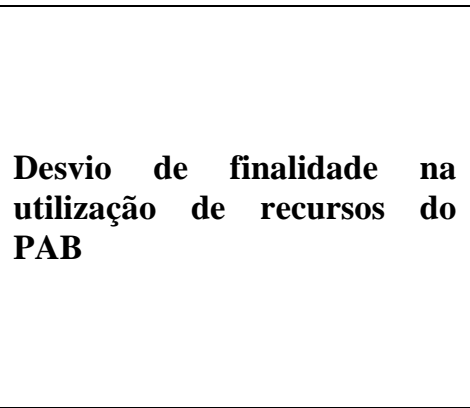 & $\begin{array}{l}\text { Realização de despesas com recursos do Piso da Atenção Básica - Parte } \\
\text { fixa em atividades e serviços distintos daqueles previstos pela legislação. } \\
\text { Neste item foram considerados todos os municípios em que foi constatado } \\
\text { algum desvio de finalidade nos recursos do PAB-Fixo. A maior parcela } \\
\text { dos municípios aqui apontados realizou despesas na própria área de saúde, } \\
\text { mas em atividades não caracterizadas como serviços de atenção primária, } \\
\text { tais como consultas e exames definidos pela Tabela de Procedimentos } \\
\text { SIA/SUS-GESUC como sendo de média ou alta complexidade. Todavia, } \\
\text { houve incidência de desvios mais graves, como o pagamento de veículo } \\
\text { em propriedade de terceiro. }\end{array}$ \\
\hline
\end{tabular}




\begin{tabular}{|c|c|}
\hline aridade & itiva \\
\hline $\begin{array}{l}\text { Irregularidades referentes } \\
\text { aos instrumentos básicos do } \\
\text { sistema de planejamento do } \\
\text { SUS }\end{array}$ & $\begin{array}{l}\text { Foram apontados neste item os municípios em que foram constadas } \\
\text { irregularidades referentes ao Plano Municipal de Saúde e/ou ao Relatório } \\
\text { de Gestão. As irregularidades são: documentos não apresentados; } \\
\text { apresentados, porém, sem as exigências previstas na legislação; não } \\
\text { aprovado pelo CMS; e/ou aprovados fora do prazo legal. }\end{array}$ \\
\hline $\begin{array}{l}\text { Falhas na gestão e } \\
\text { operacionalização do Fundo } \\
\text { Municipal de Saúde - FMS }\end{array}$ & $\begin{array}{l}\text { A legislação estabelece que os recursos destinados às ações de saúde } \\
\text { devem ser movimentados em contas especiais - os fundos de saúde - que } \\
\text { devem ser dotadas de contabilidade própria e movimentadas pelo } \\
\text { Secretário Municipal de Saúde. Neste item foram agregadas todas as } \\
\text { irregularidades que descumprem estas exigências, tais como: inexistência } \\
\text { jurídica do Fundo Municipal de Saúde; Fundo gerido pelo Prefeito; e } \\
\text { conta corrente de titularidade da prefeitura. }\end{array}$ \\
\hline $\begin{array}{l}\text { Cobrança de } r \text { consultas } \\
\text { básicas aos usuários do SUS } \\
\text { por parte de entidade } \\
\text { conveniada }\end{array}$ & $\begin{array}{l}\text { tidade conveniada ao SUS realiza cobranças aos usuários por consultas } \\
\text { isicas e exames realizados, o que caracteriza fraude, uma vez que a } \\
\text { muneração por estes serviços já estaria sendo realizada pelo SUS. }\end{array}$ \\
\hline $\begin{array}{lr}\text { Insuficiência } & \text { de } \\
\text { medicamentos } & \text { e/ou } \\
\text { deficiência no controle e } \\
\text { estocagem }\end{array}$ & $\begin{array}{l}\text { Incluem-se aqui as seguintes ocorrências: atraso na entrega de } \\
\text { medicamentos licitados pela empresa vencedora; Secretaria Municipal de } \\
\text { Saúde não possui qualquer controle ou registro dos medicamentos } \\
\text { estocados; e emissão de Notas Fiscais após a entrega de medicamentos. } \\
\text { Além de consistir em procedimento em desacordo com legislação fiscal, } \\
\text { esta última irregularidade impede que se afira se quantidade entregue } \\
\text { corresponde efetivamente à compra realizada. }\end{array}$ \\
\hline Outros & $\begin{array}{l}\text { do autor. São elas: falta de alimentação de banco d } \\
\text { obrigatórios; ausência de identificação da origem dos }\end{array}$ \\
\hline $\begin{array}{l}\text { Monitoramento deficiente } \\
\text { dos profissionais e } \\
\text { entidades conveniadas } \\
\text { atuam na atenção básica }\end{array}$ & $\begin{array}{l}\text { na Atenção Básica ou simplesmente ausência de c } \\
\text { executada, assim como em que havia impossibilid } \\
\text { prestação de serviços médicos por parte de pr } \\
\text { privadas contratados. }\end{array}$ \\
\hline $\begin{array}{l}\text { Pagamentos acima do } \\
\text { estipulado em contrato / } \\
\text { processo licitatório; } \\
\text { Pagamentos intempestivo }\end{array}$ & $\begin{array}{l}\text { es do tempo devido } \\
\text { o. }\end{array}$ \\
\hline $\begin{array}{l}\text { Aquisição de bens ou } \\
\text { contratação de serviços não } \\
\text { foi estruturada de acordo } \\
\text { com a Lei de Licitações }\end{array}$ & $\begin{array}{l}\text { Constatou-se que a presença de estrutura de contratação em desacordo } \\
\text { com as exigências da Lei } 8.666 / 1993 \text {. Dentre as irregularidades agregadas } \\
\text { neste item estão: inobservância da obrigação legal de licitar; falhas na } \\
\text { documentação suportando dispensa de licitação; fracionamento indevido } \\
\text { de despesas e enquadramento inadequado da modalidade de licitação. }\end{array}$ \\
\hline $\begin{array}{l}\text { Licitação na modalidade } \\
\text { convite com número de } \\
\text { propostas válidas inferior a } \\
\text { três }\end{array}$ & $\begin{array}{l}\text { A Lei de Licitações (8.666/93) estabelece que, na modalidade convite, } \\
\text { devem ser notificadas sobre o processo, no mínimo, três empresas. O } \\
\text { entendimento do TCU é mais rigoroso: julga ser necessário que ao menos } \\
\text { três propostas válidas sejam encaminhadas ao licitante. Esta categoria } \\
\text { considera os municípios que não cumpriram o estabelecido pelo TCU. }\end{array}$ \\
\hline $\begin{array}{l}\text { Improprieda } \\
\text { licitatórios }\end{array}$ & $\begin{array}{l}\text { Descumprimento de ao menos uma das exigências procedimentais } \\
\text { estabelecidas pela da Lei } 8.666 / 93 \text {. Nesta categoria estão incluídas aquelas } \\
\text { irregularidades de menor gravidade encontradas nas licitações } \\
\text { fiscalizadas. }\end{array}$ \\
\hline
\end{tabular}




\begin{tabular}{|c|c|}
\hline Irregularidade & Descrição e Justificativa \\
\hline $\begin{array}{l}\text { Restrição à competitividade } \\
\text { em certame licitatório }\end{array}$ & $\begin{array}{l}\text { Aqui estão classificadas as irregularidades em processos licitatórios que se } \\
\text { julga incorrerem em restrição à competitividade no certame. Dentre os } \\
\text { problemas que se enquadram neste item, se destacam: em Tomada de } \\
\text { Preços, convite a número limitado de empresas; direcionamento de } \\
\text { escolha de marca em licitação; publicação deficiente de certame; } \\
\text { convidadas empresas com sócios em comum, embora ao menos uma das } \\
\text { empresas convidadas tenha sócios diferentes; e realização de licitação do } \\
\text { tipo menor preço global. }\end{array}$ \\
\hline $\begin{array}{l}\text { Indícios de fraude em } \\
\text { processos licitatórios }\end{array}$ & $\begin{array}{l}\text { Nesta categoria estão incluídas aquelas irregularidades mais graves } \\
\text { encontradas nas licitações fiscalizadas. Dentre os problemas que se } \\
\text { enquadram neste item, se destacam: empresa participante afirma que } \\
\text { proposta anexada ao processo não foi a apresentada à prefeitura; todas as } \\
\text { empresas convidadas têm sócios em comum; contratadas empresa } \\
\text { reconhecidamente inidôneas; existe diferença padronizada nos preços } \\
\text { unitários dos itens apresentados pelos participantes da licitação, } \\
\text { caracterizando conluio entre estes; propostas apresentadas pelos } \\
\text { concorrentes possuem redação e formatação idênticas. }\end{array}$ \\
\hline $\begin{array}{l}\text { Irregularidades relativas à } \\
\text { formação } \text { e/ou ao } \\
\text { funcionamento do Conselho } \\
\text { Municipal de Saúde (CMS) }\end{array}$ & $\begin{array}{l}\text { A formação do Conselho Municipal de Saúde (CMS) e/ou o } \\
\text { funcionamento deste não atende às exigências da legislação (Resolução } \\
\text { 333/2003 CNS). } \\
\text { O CMS deve ser composto, de forma paritária, por representantes de } \\
\text { usuários, trabalhadores de saúde e governo, de forma a garantir a } \\
\text { participação da sociedade nas políticas de saúde. As principais } \\
\text { impropriedades encontradas referente à formação do CMS são: } \\
\text { composição do CMS não respeita a paridade estabelecida pela legislação; } \\
\text { não observância à resolução que determina que o Presidente do CMS deve } \\
\text { ser eleito em reunião plenária, pelos membros do conselho; e ausência de } \\
\text { Regimento Interno do conselho. } \\
\text { No que concerne ao seu funcionamento, as irregularidades são: gestor da } \\
\text { saúde atua de forma independente do CMS; as reuniões não ocorrem } \\
\text { mensalmente; atas e relatórios emitidos pelo conselho não foram } \\
\text { disponibilizados à CGU; ausência de participação na elaboração do } \\
\text { orçamento anual e demais instrumentos de gestão da saúde municipal; e } \\
\text { desconhecimento, pelo CMS, dos recursos financeiros disponibilizados e } \\
\text { aplicados nas ações de saúde. }\end{array}$ \\
\hline
\end{tabular}




\section{I.C. EstruturaÇão da Rede de SERVIÇOS dA ATENÇão BásiCa}

\begin{tabular}{|c|c|}
\hline Irregularidade & Descrição e Justificativa \\
\hline $\begin{array}{c}\text { Impropriedades em processos } \\
\text { licitatórios }\end{array}$ & $\begin{array}{l}\text { Descumprimento de ao menos uma das exigências procedimentais } \\
\text { estabelecidas pela da Lei 8.666/93. Nesta categoria estão incluídas aquelas } \\
\text { irregularidades de menor gravidade encontradas nas licitações } \\
\text { fiscalizadas. }\end{array}$ \\
\hline $\begin{array}{l}\text { Restrição à competitividade } \\
\text { em certame licitatório }\end{array}$ & $\begin{array}{l}\text { Aqui estão classificadas as irregularidades em processos licitatórios que se } \\
\text { julga incorrerem em restrição à competitividade no certame. Dentre os } \\
\text { problemas que se enquadram neste item, se destacam: em. Tomada de } \\
\text { Preços, convite a número limitado de empresas; direcionamento de } \\
\text { escolha de marca em licitação; publicação deficiente de certame; proposta } \\
\text { de participante foi desconsiderada, mediante justificativa inadequada; } \\
\text { convidadas empresas com sócios em comum, embora ao menos uma das } \\
\text { empresas convidadas tenha sócios diferentes; e realização de licitação do } \\
\text { tipo menor preço global. }\end{array}$ \\
\hline $\begin{array}{l}\text { Indícic } \\
\text { proces }\end{array}$ & $\begin{array}{l}\text { Nesta categoria estão incluídas aquelas irregularidades mais graves } \\
\text { encontradas nas licitações fiscalizadas. Dentre os problemas que se } \\
\text { enquadram neste item, se destacam: empresa participante afirma que } \\
\text { proposta anexada ao processo não foi a apresentada à prefeitura; todas as } \\
\text { empresas convidadas têm sócios em comum; contratadas empresa } \\
\text { reconhecidamente inidôneas; existe diferença padronizada nos preços } \\
\text { unitários dos itens apresentados pelos participantes da licitaçâ, } \\
\text { caracterizando conluio entre estes; propostas apresentadas pelos } \\
\text { concorrentes possuem redação e formatação idênticas. }\end{array}$ \\
\hline $\begin{array}{l}\text { Aquisição de bens ou } \\
\text { contratação de serviços não } \\
\text { foi estruturada de acordo } \\
\text { com a Lei de Licitações }\end{array}$ & $\begin{array}{l}\text { Constatou-se que a presença de estrutura de contratação em desacordo } \\
\text { com as exigências da Lei 8.666/1993. Dentre as irregularidades agregadas } \\
\text { neste item estão: inobservância da obrigação legal de licitar; falhas na } \\
\text { documentação suportando dispensa de licitação; fracionamento indevido } \\
\text { de despesas e enquadramento inadequado da modalidade de licitação. }\end{array}$ \\
\hline $\begin{array}{l}\text { Licitação na modalidade } \\
\text { convite com número de } \\
\text { propostas válidas inferior a } \\
\text { três }\end{array}$ & $\begin{array}{l}\text { A Lei de Licitações }(8.666 / 93) \text { estabelece que, na modalidade convite, } \\
\text { devem ser notificadas sobre o processo, no mínimo, três empresas. O } \\
\text { entendimento do TCU é mais rigoroso: julga ser necessário que ao menos } \\
\text { três propostas válidas sejam encaminhadas ao licitante. Esta categoria } \\
\text { considera os municípios que não cumpriram o estabelecido pelo TCU. }\end{array}$ \\
\hline $\begin{array}{l}\text { Informações incompletas no } \\
\text { preenchimento das notas } \\
\text { fiscais, conforme preceitua o } \\
\text { art. } 30^{\circ} \text { da IN/STN 01/97 } \\
\end{array}$ & $\begin{array}{l}\text { ce que, no intuito de que sejam comprovadas as } \\
\text { ênios estabelecidos com a União, todas as notas } \\
\text { as em nome do convenente com anotação do } \\
\text { iio. }\end{array}$ \\
\hline $\begin{array}{l}\text { Documentação precária } \\
\text { referente a convênio / } \\
\text { licitação }\end{array}$ & $\begin{array}{l}\text { Realização da fiscalização foi impossibilitada, pois a documentação } \\
\text { referente a convênio / licitação não foi disponibilizada ou estava disposta } \\
\text { com desorganização tal que inviabilizou a sua conferência. }\end{array}$ \\
\hline $\begin{array}{lrr}\text { Irregularidades } & \text { no } \\
\text { gerenciamento dos bens } \\
\text { adquiridos } & \text { mediante } \\
\text { convênio com a União } & \end{array}$ & $\begin{array}{l}\text { Esta categoria incorpora falhas no gerenciamento dos bens e serviços } \\
\text { adquiridos para uso na estratégia de atenção básica em saúde. Dentre } \\
\text { estas, destacam-se: bens adquiridos ou equipamentos construídos com } \\
\text { recursos de convênio não foram localizados e/ou estavam sem utilização; } \\
\text { unidades móveis de saúde sem utilização ou subutilizadas; falta de } \\
\text { plaquetas de patrimônio em equipamentos hospitalares; controle } \\
\text { insuficiente da movimentação de veículos; e uso por entidades privadas de } \\
\text { equipamento público adquirido com recursos do convênio. }\end{array}$ \\
\hline $\begin{array}{r}\text { Atrass } \\
\text { de }\end{array}$ & $\begin{array}{l}\text { Incluem-se nesta categoria as seguintes ocorrências: realização de obra } \\
\text { além do prazo previsto; e prazos de vigência expirados, sem a entrega } \\
\text { pelo fornecedor do objeto contratado. }\end{array}$ \\
\hline
\end{tabular}




\begin{tabular}{|c|c|}
\hline Irregularidade & Descrição e Justificativa \\
\hline $\begin{array}{l}\text { Descumprimento de } \\
\text { exigências perante órgão } \\
\text { concedente previstas em } \\
\text { contrato }\end{array}$ & $\begin{array}{l}\text { Foram agregadas neste item as irregularidades referentes ao } \\
\text { descumprimento de exigências perante o Ministério da Saúde previstas na } \\
\text { legislação ou contrato do convênio. Basicamente, são: a alteração de } \\
\text { objeto do convênio, sem retificação perante órgão concedente; emprego } \\
\text { do objeto em desconformidade com previsto no Plano de Trabalho; não } \\
\text { disponibilização de contrapartida conforme estipula contrato ou convênio; } \\
\text { irregularidade na aplicação financeira dos recursos mantidos em conta } \\
\text { corrente; e a não devolução de saldo de convênio remanescente para a } \\
\text { Administração Federal. }\end{array}$ \\
\hline $\begin{array}{c}\text { Liberação de recursos } \\
\text { antecipada / com o Plano de } \\
\text { Trabalho incompleto } \\
\end{array}$ & $\begin{array}{l}\text { A liberação dos recursos destinados ao pagamento do fornecedor ocorreu } \\
\text { em dissonância aos requerimentos estabelecidos pela Instrução Normativa } \\
\text { 1-97 STN. }\end{array}$ \\
\hline $\begin{array}{l}\text { Irregularidades na execução } \\
\text { e pagamento de obras de } \\
\text { unidades básicas de saúde }\end{array}$ & $\begin{array}{l}\text { Este item incorpora os seguintes problemas referentes à execução e } \\
\text { pagamento de construção e reforma de unidades de saúde: elevação do } \\
\text { valor pago em relação ao pactuado no convênio; fiscalização precária das } \\
\text { obras; substituição de serviço prestado ou material empregado por outro } \\
\text { não licitado pelo executor das obras. }\end{array}$ \\
\hline $\begin{array}{l}\text { Preços Unitários de itens } \\
\text { contratados com valores } \\
\text { acima aos de mercado / } \\
\text { superfaturamento }\end{array}$ & Auto-explicativo. \\
\hline Outros & $\begin{array}{l}\text { Aqui foram agregadas as irregularidades julgadas menos representativas, } \\
\text { seja pela incidência ou em função de reduzida gravidade, no julgamento } \\
\text { do autor. No caso deste programa, são elas: inexistência de informação } \\
\text { alusiva ao Governo Federal em unidade móvel adquirida; Plano de } \\
\text { Trabalho ou Convite não contém as especificações completas dos } \\
\text { equipamentos a adquirir; proposta em certame sem a composição de } \\
\text { custos desagregados ou adjudicação por preço global de objeto de } \\
\text { natureza divisível; e ausência de prévia pesquisa de preço de mercado na } \\
\text { aquisição ou locação de unidades móveis de saúde e demais } \\
\text { equipamentos. }\end{array}$ \\
\hline
\end{tabular}




\section{ANEXO II - RESULTADOS ECONOMÉTRICOS}

Tabela II.1. Taxa de Mortalidade Materna - Todos os Municípios

\begin{tabular}{|c|c|c|c|}
\hline Variável & POLS & Efeitos Aleatórios & Efeitos Fixos \\
\hline \multirow[t]{2}{*}{ PSF } & $-0,005$ & $-0,005$ & 0,002 \\
\hline & 0,010 & 0,008 & 0,015 \\
\hline \multirow[t]{2}{*}{ PACS } & $-0,011$ & $-0,011$ & $-0,030$ \\
\hline & 0,011 & 0,016 & 0,026 \\
\hline \multirow[t]{2}{*}{ PIBPC } & $-7,03 E-08$ & $-7,03 E-08$ & $-2,04 E-07$ \\
\hline & $2,29 \mathrm{E}-07$ & $3,40 \mathrm{E}-07$ & $8,69 \mathrm{E}-07$ \\
\hline \multirow[t]{2}{*}{ HOSP } & $\mathbf{0 , 0 0 0}$ & 0,000 & 0,001 \\
\hline & 0,000 & 0,001 & 0,006 \\
\hline \multirow[t]{2}{*}{ OBST } & $-0,004$ & $-0,004$ & $-0,021$ \\
\hline & 0,007 & 0,008 & 0,035 \\
\hline \multirow[t]{2}{*}{ IDIPC } & 9,91E-06 & 9,91E-06 & 1,93E-05 \\
\hline & 7,94E-06 & $7,94 \mathrm{E}-06$ & $1,39 \mathrm{E}-05$ \\
\hline \multirow[t]{2}{*}{ EVAS_EF } & $\mathbf{0 , 0 0 1}$ & 0,001 & 0,002 \\
\hline & 0,001 & 0,001 & 0,001 \\
\hline \multirow[t]{2}{*}{ EVAS_EM } & $\mathbf{0 , 0 0 0}$ & $\mathbf{0 , 0 0 0}$ & $\mathbf{0 , 0 0 0}$ \\
\hline & 0,000 & 0,000 & 0,001 \\
\hline \multirow[t]{2}{*}{ D00 } & 0,010 & $\mathbf{0 , 0 1 0}$ & $\mathbf{0 , 0 1 0}$ \\
\hline & 0,015 & 0,010 & 0,010 \\
\hline \multirow[t]{2}{*}{ D01 } & $-0,008$ & $-0,008$ & $-0,010$ \\
\hline & 0,011 & 0,010 & 0,011 \\
\hline \multirow[t]{2}{*}{ D02 } & $-0,003$ & $-0,003$ & $-0,007$ \\
\hline & 0,011 & 0,011 & 0,012 \\
\hline \multirow[t]{2}{*}{ D03 } & $-0,002$ & $-0,002$ & $-0,006$ \\
\hline & 0,012 & 0,011 & 0,013 \\
\hline \multirow[t]{2}{*}{ _CONS } & $0,039 * * *$ & $0,039 * * *$ & $0,040 * * *$ \\
\hline & 0,014 & 0,011 & 0,022 \\
\hline Breusch-Pagan - $\chi^{2}(1)$ & & 0,48 & \\
\hline Hausman $-\chi^{2}(11)$ & & & N/D \\
\hline $\mathbf{R}^{2}$ & 0,0017 & & 0,0019 \\
\hline $\mathbf{F}$ & 0,73 & & 1,04 \\
\hline Observações & 8.155 & 8.155 & 8.155 \\
\hline
\end{tabular}

Nota: Erro padrão entre parênteses. $* * *, * * \mathrm{e} *$ indicam significância estatística respectivamente a $1 \%, 5 \%$ e $10 \%$. 
Tabela II.2. Taxa de Mortalidade Materna - Amostra de municípios com população superior a 50.000 habitantes

\begin{tabular}{|c|c|c|c|}
\hline Variável & POLS & Efeitos Aleatórios & Efeitos Fixos \\
\hline \multirow{2}{*}{ PSF } & $-0,009$ & $-0,009$ & $-0,013$ \\
\hline & $(0,009)$ & $(0,010)$ & $(0,017)$ \\
\hline \multirow[t]{2}{*}{ PACS } & $\mathbf{0 , 0 0 7}$ & 0,006 & $\mathbf{0 , 0 0 0}$ \\
\hline & $(0,011)$ & $(0,011)$ & $(0,019)$ \\
\hline \multirow[t]{2}{*}{ PIBPC } & -1,62E-07 & $-2,10 E-07$ & $-7,68 \mathrm{E}-07 *$ \\
\hline & $(1,29 \mathrm{E}-07)$ & $(2,01 \mathrm{E}-07)$ & $(4,42 \mathrm{E}-07)$ \\
\hline \multirow[t]{2}{*}{ HOSP } & $0,001 * *$ & $0,001 * *$ & $-0,001$ \\
\hline & $(0,001)$ & $(0,001)$ & $(0,003)$ \\
\hline \multirow[t]{2}{*}{ OBST } & $-0,021 * *$ & $-0,020 * *$ & $-0,006$ \\
\hline & $(0,009)$ & $(0,010)$ & $(0,028)$ \\
\hline \multirow[t]{2}{*}{ IDIPC } & 1,24E-05 & 0,000012 & 5,06E-07 \\
\hline & $(7,66 \mathrm{E}-06)$ & $(8,46 \mathrm{E}-06)$ & $(1,89 \mathrm{E}-05)$ \\
\hline \multirow[t]{2}{*}{ EVAS_EF } & $0,002 * *$ & $0,002 * *$ & $-0,001$ \\
\hline & $(0,001)$ & $(0,001)$ & $(0,001)$ \\
\hline \multirow[t]{2}{*}{ EVAS_EM } & 0,000 & $\mathbf{0 , 0 0 0}$ & 0,000 \\
\hline & $(0,000)$ & $(0,000)$ & $(0,001)$ \\
\hline \multirow[t]{2}{*}{ D00 } & $-0,003$ & $-0,003$ & $-0,004$ \\
\hline & $(0,006)$ & $(0,005)$ & $(0,005)$ \\
\hline \multirow[t]{2}{*}{ D01 } & $-0,005$ & $-0,005$ & $-0,012 *$ \\
\hline & $(0,006)$ & $(0,006)$ & $(0,006)$ \\
\hline \multirow[t]{2}{*}{ D02 } & $-0,003$ & $-0,004$ & $-0,012$ \\
\hline & $(0,006)$ & $(0,006)$ & $(0,007)$ \\
\hline \multirow[t]{2}{*}{ D03 } & $-0,008$ & $-0,009$ & $-0,016 *$ \\
\hline & $(0,006)$ & $(0,006)$ & $(0,008)$ \\
\hline \multirow[t]{2}{*}{ _CONS } & $0,045 * * *$ & $0,047 * * *$ & $0,081 * * *$ \\
\hline & $(0,007)$ & $(0,008)$ & $(0,018)$ \\
\hline Breusch-Pagan - $\chi^{2}(1)$ & & $10,05 * * *$ & \\
\hline Hausman $-\chi^{2}(11)$ & & & 16,28 \\
\hline $\mathbf{R}^{2}$ & 0,0273 & & 0,0173 \\
\hline $\mathbf{F}$ & $2,47 * * *$ & & 1,32 \\
\hline Observações & 1.135 & 1.135 & 1.135 \\
\hline
\end{tabular}

Nota: Erro padrão entre parênteses. $* * *, * * \mathrm{e}^{*}$ indicam significância estatística respectivamente a $1 \%, 5 \%$ e $10 \%$. 
Tabela II.3. Taxa de Mortalidade Infantil - Todos os Municípios

\begin{tabular}{|c|c|c|c|}
\hline Variável & POLS & Efeitos Aleatórios & Efeitos Fixos \\
\hline \multirow[t]{2}{*}{ PSF } & 0,94 & 0,94 & 0,97 \\
\hline & $(0,91)$ & $(1,00)$ & $(1,74)$ \\
\hline \multirow[t]{2}{*}{ PACS } & $\mathbf{0 , 3 8}$ & 0,29 & $-1,63$ \\
\hline & $(1,08)$ & $(1,88)$ & $(3,04)$ \\
\hline \multirow[t]{2}{*}{ PIBPC } & $-0,00006$ & $-0,00006$ & 0,00007 \\
\hline & $(0,00004)$ & $(0,00004)$ & $(0,00010)$ \\
\hline \multirow[t]{2}{*}{ HOSP } & $-0,04$ & $-0,04$ & $-0,73$ \\
\hline & $(0,06)$ & $(0,13)$ & $(0,74)$ \\
\hline \multirow[t]{2}{*}{ OBST } & $\mathbf{0 , 5 2}$ & 0,56 & 4,96 \\
\hline & $(0,81)$ & $(0,97)$ & $(4,04)$ \\
\hline \multirow[t]{2}{*}{ IDIPC } & 0,0014 & 0,0014 & 0,0023 \\
\hline & $(0,0010)$ & $(0,0009)$ & $(0,0016)$ \\
\hline \multirow[t]{2}{*}{ EVAS_EF } & $\mathbf{0 , 3 6 * * *}$ & $\mathbf{0 , 3 5} * * *$ & 0,14 \\
\hline & $(0,08)$ & $(0,10)$ & $(0,15)$ \\
\hline \multirow[t]{2}{*}{ EVAS_EM } & $0,14 * * *$ & $0,14 * * *$ & $\mathbf{0 , 0 1}$ \\
\hline & $(0,05)$ & $(0,05)$ & $(0,06)$ \\
\hline \multirow[t]{2}{*}{ D00 } & $-1,58$ & $-1,61$ & $-2,37 * *$ \\
\hline & $(1,58)$ & $(1,12)$ & $(1,16)$ \\
\hline \multirow[t]{2}{*}{ D01 } & $-4,26 * * *$ & $-4,31 * * *$ & $-5,80 * * *$ \\
\hline & $(1,29)$ & $(1,17)$ & $(1,30)$ \\
\hline \multirow[t]{2}{*}{ D02 } & $-4,96 * * *$ & $-5,02 * * *$ & $-6,81 * * *$ \\
\hline & $(1,30)$ & $(1,22)$ & $(1,43)$ \\
\hline \multirow[t]{2}{*}{ D03 } & $-4,44 * * *$ & $-4,52 * * *$ & $-6,68 * * *$ \\
\hline & $(1,30)$ & $(1,24)$ & $(1,50)$ \\
\hline \multirow[t]{2}{*}{ _CONS } & $18,03 * *$ & $18,18 * * *$ & $21,53 * * *$ \\
\hline & $(1,34)$ & $(1,33)$ & $(2,48)$ \\
\hline Breusch-Pagan - $\chi^{2}(1)$ & & $2,92 *$ & \\
\hline Hausman $-\chi^{2}(11)$ & & & $19,11 *$ \\
\hline $\mathbf{R}^{2}$ & 0,0148 & 0,0085 & 0,0101 \\
\hline $\mathbf{F}$ & $6,74 * * *$ & & $5,54 * * *$ \\
\hline Observações & 8.157 & 8.157 & 8.157 \\
\hline
\end{tabular}

Nota: Erro padrão entre parênteses. $* * *, * * \mathrm{e}^{*}$ indicam significância estatística respectivamente a $1 \%, 5 \%$ e $10 \%$. 
Tabela II.4. Taxa de Mortalidade Neonatal - Todos os Municípios

\begin{tabular}{|c|c|c|c|}
\hline Variável & POLS & Efeitos Aleatórios & Efeitos Fixos \\
\hline PSF & $\begin{array}{c}\mathbf{- 0 , 1 3} \\
(0,59)\end{array}$ & $\begin{array}{l}\mathbf{- 0 , 1 1} \\
(0,63)\end{array}$ & $\begin{array}{c}\mathbf{0 , 2 0} \\
(1,06)\end{array}$ \\
\hline PACS & $\begin{array}{c}\mathbf{0 , 2 2} \\
(0,73)\end{array}$ & $\begin{array}{c}\mathbf{0 , 1 6} \\
(1,19)\end{array}$ & $\begin{array}{l}\mathbf{- 0 , 3 0} \\
(1,86)\end{array}$ \\
\hline PIBPC & $\begin{array}{l}\mathbf{- 0 , 0 0 0 0 3} \\
(0,00002)\end{array}$ & $\begin{array}{c}\mathbf{- 0 , 0 0 0 0 3} \\
(0,00003)\end{array}$ & $\begin{array}{c}\mathbf{0 , 0 0 0 0 2} \\
(0,00006)\end{array}$ \\
\hline HOSP & $\begin{array}{c}\mathbf{0 , 0 5} \\
(0,05)\end{array}$ & $\begin{array}{c}\mathbf{0 , 0 4} \\
(0,09)\end{array}$ & $\begin{array}{l}\mathbf{- 0 , 4 8} \\
(0,45)\end{array}$ \\
\hline OBST & $\begin{array}{c}\mathbf{0 , 4 9} \\
(0,55)\end{array}$ & $\begin{array}{c}\mathbf{0 , 5 5} \\
(0,63)\end{array}$ & $\begin{array}{c}\mathbf{3 , 6 8} \\
(2,47)\end{array}$ \\
\hline IDIPC & $\begin{array}{c}\mathbf{0 , 0 0 0 2} \\
(0,0005)\end{array}$ & $\begin{array}{c}\mathbf{0 , 0 0 0 2} \\
(0,0006)\end{array}$ & $\begin{array}{c}\mathbf{0 , 0 0 0 7} \\
(0,0010)\end{array}$ \\
\hline EVAS_EF & $\begin{array}{c}\mathbf{0 , 1 9} * * * \\
(0,06)\end{array}$ & $\begin{array}{c}\mathbf{0 , 1 8} * * * \\
(0,06)\end{array}$ & $\begin{array}{c}\mathbf{0 , 0 9} \\
(0,09)\end{array}$ \\
\hline EVAS_EM & $\begin{array}{c}\mathbf{0 , 0 9} * * \\
(0,03)\end{array}$ & $\begin{array}{c}\mathbf{0 , 0 8} * * * \\
(0,03)\end{array}$ & $\begin{array}{c}\mathbf{0 , 0 2} \\
(0,04)\end{array}$ \\
\hline D00 & $\begin{array}{c}\mathbf{- 0 , 7 8} \\
(0,90)\end{array}$ & $\begin{array}{l}\mathbf{- 0 , 8 2} \\
(0,68)\end{array}$ & $\begin{array}{l}\mathbf{- 1 , 2 3 *} \\
(0,71)\end{array}$ \\
\hline D01 & $\begin{array}{c}\mathbf{- 1 , 7 7 * *} \\
(0,78)\end{array}$ & $\begin{array}{c}\mathbf{- 1 , 8 4} * * \\
(0,71)\end{array}$ & $\begin{array}{c}\mathbf{- 2 , 6 1} * * * \\
(0,79)\end{array}$ \\
\hline D02 & $\begin{array}{c}\mathbf{- 1 , 8 4 * *} \\
(0,80)\end{array}$ & $\begin{array}{c}-\mathbf{1 , 9 1} * * \\
(0,74)\end{array}$ & $\begin{array}{c}\mathbf{- 2 , 8 1} * * * \\
(0,87)\end{array}$ \\
\hline D03 & $\begin{array}{c}\mathbf{- 1 , 9 8 * *} \\
(0,80)\end{array}$ & $\begin{array}{c}\mathbf{- 2 , 0 7 * * *} \\
(0,76)\end{array}$ & $\begin{array}{c}\mathbf{- 3 , 1 7} * * * \\
(0,92)\end{array}$ \\
\hline _CONS & $\begin{array}{c}12,12 * * * \\
(0,82)\end{array}$ & $\begin{array}{c}12,29 * * * \\
(0,84) \\
\end{array}$ & $\begin{array}{c}13,75 * * * \\
(1,52) \\
\end{array}$ \\
\hline Breusch-Pagan - $\chi^{2}(1)$ & & $7,41 * * *$ & \\
\hline Hausman $-\chi^{2}(11)$ & & & 11,68 \\
\hline $\mathbf{R}^{2}$ & 0,0103 & 0,0057 & 0,0067 \\
\hline $\mathbf{F}$ & $4,48 * * *$ & & $3,63 * * *$ \\
\hline Observações & 8.157 & 8.157 & 8.157 \\
\hline
\end{tabular}

Nota: Erro padrão entre parênteses. $* * *, * *$ e * indicam significância estatística respectivamente a $1 \%, 5 \%$ e $10 \%$.

Tabela II.5. Taxa de Mortalidade Neonatal - Amostra de municípios com população inferior a 50.000 habitantes

\begin{tabular}{|l|cccc|}
\hline \hline V. Dependente & \multicolumn{4}{|c|}{ Taxa de Mortalidade Total } \\
\hline \hline & Coef. & Erro Pad & $\mathbf{t}$ & $\mathbf{P}>|\mathbf{t}|$ \\
\hline PSF & $\mathbf{- 2 . 1 8}$ & 1.02 & -2.14 & $\mathbf{0 . 0 3 3}$ \\
\hline PACS & $\mathbf{- 0 . 2 0}$ & 1.13 & -0.18 & $\mathbf{0 . 8 6 0}$ \\
\hline PIBPC & $\mathbf{0 . 0 0 0 0 2}$ & 0.00003 & 0.62 & $\mathbf{0 . 5 3 6}$ \\
\hline HOSP & $\mathbf{0 . 1 4}$ & 0.20 & 0.72 & $\mathbf{0 . 4 7 4}$ \\
\hline OBST & $\mathbf{0 . 0 5}$ & 1.66 & 0.03 & $\mathbf{0 . 9 7 6}$ \\
\hline IDIPC & $\mathbf{0 . 0 0 0 6}$ & 0.0011 & 0.52 & $\mathbf{0 . 6 0 0}$ \\
\hline DES_EF & $\mathbf{- 0 . 0 1}$ & 0.07 & -0.18 & $\mathbf{0 . 8 5 9}$ \\
\hline EVAS_EF & $\mathbf{- 0 . 0 6}$ & 0.04 & -1.80 & $\mathbf{0 . 0 7 2}$ \\
\hline D00 & $\mathbf{- 0 . 0 5}$ & 0.32 & -0.14 & $\mathbf{0 . 8 8 6}$ \\
\hline D01 & $\mathbf{- 1 . 6 0}$ & 0.39 & -4.11 & $\mathbf{0 . 0 0 0}$ \\
\hline D02 & $\mathbf{- 1 . 7 4}$ & 0.44 & -3.91 & $\mathbf{0 . 0 0 0}$ \\
\hline D03 & $\mathbf{- 2 . 3 3}$ & 0.49 & -4.75 & $\mathbf{0 . 0 0 0}$ \\
\hline CONS & $\mathbf{1 4 . 2 0}$ & 1.08 & 13.11 & $\mathbf{0 . 0 0 0}$ \\
\hline
\end{tabular}

\begin{tabular}{|c|}
\hline $\begin{array}{c}\text { Observações } \\
1135\end{array}$ \\
\hline Hausman - $\boldsymbol{\chi}^{\mathbf{2}} \mathbf{( 1 1 )}$ \\
41,94 \\
\hline Breusch-Pagan - $\boldsymbol{\chi}^{\mathbf{2}} \mathbf{( 1 )}$ \\
396,25 \\
\hline $\mathbf{R}^{\mathbf{2}}$ \\
0,1150 \\
\hline $\mathbf{F}(\mathbf{1 2 , 8 9 6})$ \\
9,70 \\
\end{tabular}


Tabela II.6. Taxa de Mortalidade Pós-neonatal - Todos os Municípios

\begin{tabular}{|c|c|c|c|}
\hline Variável & POLS & Efeitos Aleatórios & Efeitos Fixos \\
\hline PSF & $\begin{array}{c}\mathbf{1 , 0 0} \\
(0,64)\end{array}$ & $\begin{array}{c}\mathbf{1 , 0 0} \\
(0,59)\end{array}$ & $\begin{array}{c}\mathbf{0 , 6 4} \\
(1,06)\end{array}$ \\
\hline PACS & $\begin{array}{c}\mathbf{0 , 1 8} \\
(0,63)\end{array}$ & $\begin{array}{c}\mathbf{0 , 1 8} \\
(1,12)\end{array}$ & $\begin{array}{c}\mathbf{- 1 , 4 1} \\
(1,86)\end{array}$ \\
\hline PIBPC & $\begin{array}{l}\mathbf{- 0 , 0 0 0 0 3} \\
(0,00002)\end{array}$ & $\begin{array}{l}\mathbf{- 0 , 0 0 0 0 3} \\
(0,00002)\end{array}$ & $\begin{array}{c}\mathbf{0 , 0 0 0 0 5} \\
(0,00006)\end{array}$ \\
\hline HOSP & $\begin{array}{l}\mathbf{- 0 , 0 9} \\
(0,03)\end{array}$ & $\begin{array}{l}\mathbf{- 0 , 0 9} \\
(0,08)\end{array}$ & $\begin{array}{l}\mathbf{- 0 , 2 6} \\
(0,45)\end{array}$ \\
\hline OBST & $\begin{array}{l}\mathbf{- 0 , 0 2} \\
(0,42)\end{array}$ & $\begin{array}{l}\mathbf{- 0 , 0 2} \\
(0,57)\end{array}$ & $\begin{array}{c}\mathbf{1 , 1 3} \\
(2,48)\end{array}$ \\
\hline IDIPC & $\begin{array}{c}\mathbf{0 , 0 0 1 2} \\
(0,0006)\end{array}$ & $\begin{array}{c}\mathbf{0 , 0 0 1 2} \\
(0,0006)\end{array}$ & $\begin{array}{c}\mathbf{0 , 0 0 1 6} \\
(0,0010)\end{array}$ \\
\hline EVAS_EF & $\begin{array}{c}\mathbf{0 , 1 5} \\
(0,05)\end{array}$ & $\begin{array}{c}\mathbf{0 , 1 5} \\
(0,06)\end{array}$ & $\begin{array}{c}\mathbf{0 , 0 4} \\
(0,09)\end{array}$ \\
\hline EVAS_EM & $\begin{array}{c}\mathbf{0 , 0 6} \\
(0,03)\end{array}$ & $\begin{array}{c}\mathbf{0 , 0 6} \\
(0,03)\end{array}$ & $\begin{array}{l}\mathbf{- 0 , 0 1} \\
(0,04)\end{array}$ \\
\hline D00 & $\begin{array}{l}\mathbf{- 0 , 7 4} \\
(1,00)\end{array}$ & $\begin{array}{l}\mathbf{- 0 , 7 4} \\
(0,69)\end{array}$ & $\begin{array}{l}\mathbf{- 1 , 0 6} \\
(0,71)\end{array}$ \\
\hline D01 & $\begin{array}{l}\mathbf{- 2 , 4 7} \\
(0,84)\end{array}$ & $\begin{array}{l}\mathbf{- 2 , 4 7} \\
(0,72)\end{array}$ & $\begin{array}{l}\mathbf{- 3 , 1 3} \\
(0,80)\end{array}$ \\
\hline D02 & $\begin{array}{l}\mathbf{- 3 , 2 8} \\
(0,85)\end{array}$ & $\begin{array}{l}\mathbf{- 3 , 2 8} \\
(0,74)\end{array}$ & $\begin{array}{l}-4,12 \\
(0,87)\end{array}$ \\
\hline D03 & $\begin{array}{l}\mathbf{- 2 , 5 4} \\
(0,86)\end{array}$ & $\begin{array}{l}\mathbf{- 2 , 5 4} \\
(0,76)\end{array}$ & $\begin{array}{l}-\mathbf{3 , 5 5} \\
(0,92)\end{array}$ \\
\hline _CONS & $\begin{array}{c}\mathbf{5 , 9 6} \\
(0,80) \\
\end{array}$ & $\begin{array}{c}\mathbf{5 , 9 6} \\
(0,79) \\
\end{array}$ & $\begin{array}{c}\mathbf{7 , 8 5} \\
(1,52) \\
\end{array}$ \\
\hline Breusch-Pagan - $\chi^{2}(1)$ & & 0,6630 & \\
\hline Hausman - $\chi^{2}(11)$ & & & 7,88 \\
\hline $\mathbf{R}^{2}$ & 0,0106 & 0,0065 & 0,0077 \\
\hline $\mathbf{F}$ & $6,34 * * *$ & & $4,21 * * *$ \\
\hline Observações & 8.157 & 8.157 & 8.157 \\
\hline
\end{tabular}

Nota: Erro padrão entre parênteses. $* * *, * * \mathrm{e} *$ indicam significância estatística respectivamente a $1 \%, 5 \% \mathrm{e}$ $10 \%$.

Tabela II.7. Taxa de Mortalidade Pós-neonatal - Amostra de municípios com população inferior a 50.000 habitantes

\begin{tabular}{|l|cccc|}
\hline \hline V. Dependente & \multicolumn{4}{|c|}{ Taxa de Mortalidade Total } \\
\hline \hline & Coef. & Erro Pad & $\mathbf{t}$ & $\mathbf{P}>|\mathbf{t}|$ \\
\hline PSF & $\mathbf{- 0 . 1 3}$ & 0.59 & -0.23 & $\mathbf{0 . 8 2 0}$ \\
\hline PACS & $\mathbf{- 0 . 5 8}$ & 0.65 & -0.89 & $\mathbf{0 . 3 7 5}$ \\
\hline PIBPC & $\mathbf{0 . 0 0 0 0 2}$ & 0.00002 & 1.01 & $\mathbf{0 . 3 1 4}$ \\
\hline HOSP & $\mathbf{- 0 . 0 6}$ & 0.11 & -0.57 & $\mathbf{0 . 5 6 9}$ \\
\hline OBST & $\mathbf{- 0 . 2 8}$ & 0.96 & -0.29 & $\mathbf{0 . 7 7 4}$ \\
\hline IDIPC & $\mathbf{0 . 0 0 0 3 5}$ & 0.00065 & 0.54 & $\mathbf{0 . 5 9 1}$ \\
\hline DES_EF & $\mathbf{0 . 0 1}$ & 0.04 & 0.22 & $\mathbf{0 . 8 2 2}$ \\
\hline EVAS_EF & $\mathbf{- 0 . 0 3}$ & 0.02 & -1.54 & $\mathbf{0 . 1 2 3}$ \\
\hline D00 & $\mathbf{- 0 . 0 3}$ & 0.18 & -0.14 & $\mathbf{0 . 8 9 0}$ \\
\hline D01 & $\mathbf{- 0 . 4 1}$ & 0.22 & -1.84 & $\mathbf{0 . 0 6 6}$ \\
\hline D02 & $\mathbf{- 1 . 3 6}$ & 0.26 & -5.31 & $\mathbf{0 . 0 0 0}$ \\
\hline D03 & $\mathbf{- 1 . 0 9}$ & 0.28 & -3.88 & $\mathbf{0 . 0 0 0}$ \\
\hline CONS & $\mathbf{6 . 2 5}$ & 0.62 & 10.03 & $\mathbf{0 . 0 0 0}$ \\
\hline
\end{tabular}

\begin{tabular}{|c|}
\hline Observações \\
1135 \\
\hline Hausman - $\boldsymbol{\chi}^{\mathbf{2}}(\mathbf{1 1})$ \\
26,06 \\
\hline Breusch-Pagan - $\boldsymbol{\chi}^{\mathbf{2}}(\mathbf{1})$ \\
177,69 \\
\hline $\mathbf{R}^{\mathbf{2}}$ \\
0,0906 \\
\hline $\mathbf{F}(\mathbf{1 2 , 8 9 6})$ \\
7,44 \\
\end{tabular}


Tabela II.8. Índice de Anos de Vida Perdidos Descontado

\begin{tabular}{|c|c|c|c|c|c|c|c|c|}
\hline \multirow[t]{3}{*}{ V. Dependente } & \multicolumn{8}{|c|}{ Índice de Anos de Vida Perdidos - Taxa de Desconto de 2,0\% a.a. } \\
\hline & \multicolumn{4}{|c|}{ IAVP } & \multicolumn{4}{|c|}{ IAVP Exclusive Causas Externas } \\
\hline & Coef. & Erro Pad & $\mathbf{t}$ & $\mathbf{P}>|\mathbf{t}|$ & Coef. & Erro Pad & $\mathbf{t}$ & $\mathbf{P}>|\mathbf{t}|$ \\
\hline PSF & 3,12 & 1,15 & 2,72 & 0,007 & 2,53 & 1,01 & 2,49 & $\mathbf{0 , 0 1 3}$ \\
\hline PACS & 3,49 & 2,04 & 1,71 & 0,087 & 4,27 & 1,80 & 2,37 & $\mathbf{0 , 0 1 8}$ \\
\hline PIBPC & 0,00001 & 0,00007 & 0,18 & $\mathbf{0 , 8 5 5}$ & $-0,00000$ & 0,00006 & $-0,04$ & 0,968 \\
\hline HOSP & 0,92 & 0,37 & 2,48 & 0,013 & 0,74 & 0,33 & 2,25 & 0,024 \\
\hline IDIPC & 0,003 & 0,001 & 2,91 & 0,004 & $\mathbf{0 , 0 0 3 4}$ & 0,0009 & 3,60 & $\mathbf{0 , 0 0 0}$ \\
\hline DES_EF & 0,022 & 0,033 & 0,66 & $\mathbf{0 , 5 1 0}$ & 0,01 & 0,03 & 0,47 & 0,636 \\
\hline EVAS_EF & 0,11 & 0,10 & 1,07 & 0,285 & $\mathbf{0 , 1 3}$ & 0,09 & 1,51 & $\mathbf{0 , 1 3 2}$ \\
\hline D00 & $-2,06$ & 0,76 & $-2,69$ & 0,007 & $-1,37$ & 0,67 & $-2,03$ & 0,042 \\
\hline D01 & $-5,27$ & 0,86 & $-6,11$ & 0,000 & $-4,03$ & 0,76 & $-5,28$ & 0,000 \\
\hline D02 & $-6,06$ & 0,96 & $-6,35$ & 0,000 & $-5,97$ & 0,84 & $-7,07$ & 0,000 \\
\hline D03 & $-4,47$ & 1,01 & $-4,40$ & 0,000 & $-3,79$ & 0,90 & $-4,22$ & 0,000 \\
\hline CONS & 76,98 & 2,39 & 32,19 & 0,000 & 62,11 & 2,11 & 29,38 & $\mathbf{0 , 0 0 0}$ \\
\hline Observações & \multicolumn{4}{|c|}{8320} & \multicolumn{4}{|c|}{8320} \\
\hline Hausman - $\chi^{2}(10)$ & \multicolumn{4}{|c|}{109,36} & \multicolumn{4}{|c|}{65,41} \\
\hline Breusch-Pagan - $\chi^{2}(1)$ & \multicolumn{4}{|c|}{2386,25} & \multicolumn{4}{|c|}{1647,55} \\
\hline & \multicolumn{4}{|c|}{0,0145} & \multicolumn{4}{|c|}{0,0184} \\
\hline$F(11,6645)$ & \multicolumn{4}{|c|}{8,92} & \multicolumn{4}{|c|}{11,32} \\
\hline
\end{tabular}

Tabela II.9. Taxa de Mortalidade de Residentes

\begin{tabular}{|l|cccc|}
\hline \hline V. Dependente & \multicolumn{4}{|c|}{ Taxa de Mortalidade Total } \\
\hline \hline & Coef. & Erro Pad & $\mathbf{t}$ & P>|t $\mid$ \\
\hline PSF & $\mathbf{0 , 0 1 8}$ & 0,006 & 2,90 & $\mathbf{0 , 0 0 4}$ \\
\hline PACS & $\mathbf{0 , 0 2 3}$ & 0,011 & 2,11 & $\mathbf{0 , 0 3 5}$ \\
\hline PIBPC & $\mathbf{1 , 0 7}^{*} \mathbf{1 0}^{-\mathbf{6}}$ & $3,65^{*} 10^{-6}$ & 0,29 & $\mathbf{0 , 7 7 0}$ \\
\hline HOSP & $\mathbf{0 , 0 0 9}$ & 0,002 & 4,55 & $\mathbf{0 , 0 0 0}$ \\
\hline IDIPC & $\mathbf{2 5 , 9} * \mathbf{1 0}^{-\mathbf{6}}$ & $5,81 * 10^{-6}$ & 4,46 & $\mathbf{0 , 0 0 0}$ \\
\hline DES_EF & $\mathbf{2 , 5 6} * \mathbf{1 0}^{-4}$ & $1,81 * 10^{-4}$ & 1,42 & $\mathbf{0 , 1 5 7}$ \\
\hline EVAS_EF & $\mathbf{0 , 0 0 1}$ & 0,001 & 2,07 & $\mathbf{0 , 0 3 9}$ \\
\hline D00 & $\mathbf{0 , 0 0 1}$ & 0,004 & 0,35 & $\mathbf{0 , 7 2 5}$ \\
\hline D01 & $\mathbf{- 0 , 0 1 7}$ & 0,005 & $-3,62$ & $\mathbf{0 , 0 0 0}$ \\
\hline D02 & $\mathbf{- 0 , 0 1 9}$ & 0,005 & $-3,61$ & $\mathbf{0 , 0 0 0}$ \\
\hline D03 & $\mathbf{0 , 0 0 3}$ & 0,006 & 0,63 & $\mathbf{0 , 5 2 7}$ \\
\hline CONS & $\mathbf{0 , 5 2 5}$ & 0,013 & 40,36 & $\mathbf{0 , 0 0 0}$ \\
\hline \hline
\end{tabular}

\begin{tabular}{|c|}
\hline Observações \\
8314 \\
\hline Hausman $-\boldsymbol{\chi}^{\mathbf{2}}(\mathbf{1 0})$ \\
208,7 \\
\hline Breusch-Pagan - $\boldsymbol{\chi}^{\mathbf{2}}(\mathbf{1})$ \\
3718,91 \\
\hline $\mathbf{R}^{\mathbf{2}}$ \\
0,0173 \\
\hline $\mathbf{F}(\mathbf{1 1 , 6 6 3 9})$ \\
10,64 \\
\hline
\end{tabular}


Tabela II.10. AIH Pagas

\begin{tabular}{|c|c|c|c|c|c|c|c|c|}
\hline \multirow[t]{3}{*}{ V. Dependente } & \multicolumn{8}{|c|}{ AIH Pagas } \\
\hline & \multicolumn{4}{|c|}{ Municípios com hospitais } & \multicolumn{4}{|c|}{ Municípios sem hospitais } \\
\hline & Coef. & Erro Pad & $\mathbf{t}$ & $\mathbf{P}>|\mathbf{t}|$ & Coef. & Erro Pad & $\mathbf{t}$ & $\mathbf{P}>|\mathbf{t}|$ \\
\hline PSF & 447,60 & 134,64 & 3,32 & 0,001 & $-527,13$ & 358,75 & $-1,47$ & 0,142 \\
\hline PACS & 558,89 & 204,00 & 2,74 & 0,006 & $-386,90$ & 709,87 & $-0,55$ & $\mathbf{0 , 5 8 6}$ \\
\hline PIBPC & $-0,0001$ & 0,0068 & $-0,01$ & 0,991 & $-0,004$ & 0,023 & $-0,15$ & $\mathbf{0 , 8 7 8}$ \\
\hline HOSP & 301,47 & 32,22 & 9,36 & 0,000 & 93,15 & 154,68 & 0,60 & $\mathbf{0 , 5 4 7}$ \\
\hline ODIPC & 9,5246 & 1,6258 & 5,86 & 0,000 & 3,94 & 4,15 & 0,95 & 0,342 \\
\hline DICEFG & 4,19 & 3,59 & 1,17 & 0,243 & 13,78 & 9,75 & 1,41 & 0,158 \\
\hline DES_EF & $-2,75$ & 4,10 & $-0,67$ & 0,502 & $-51,42$ & 9,99 & $-5,15$ & $\mathbf{0 , 0 0 0}$ \\
\hline D00 & $-159,40$ & 72,01 & $-2,21$ & $\mathbf{0 , 0 2 7}$ & 593,42 & 288,61 & 2,06 & 0,040 \\
\hline D01 & $-433,58$ & 86,49 & $-5,01$ & 0,000 & 260,93 & 327,17 & 0,80 & 0,425 \\
\hline D02 & $-643,82$ & 108,76 & $-5,92$ & $\mathbf{0 , 0 0 0}$ & $-21,54$ & 360,32 & $-0,06$ & $\mathbf{0 , 9 5 2}$ \\
\hline D03 & $-788,64$ & 107,07 & $-7,37$ & 0,000 & 20,47 & 363,77 & 0,06 & 0,955 \\
\hline CONS & $7.345,13$ & 328,50 & 22,36 & 0,000 & $8.816,03$ & 760,39 & 11,59 & 0,000 \\
\hline Observações & \multicolumn{4}{|c|}{4664} & \multicolumn{4}{|c|}{3653} \\
\hline Hausman - $\chi^{2}(10)$ & \multicolumn{4}{|c|}{56,23} & \multicolumn{4}{|c|}{56,09} \\
\hline Breusch-Pagan - $\chi^{2}(1)$ & \multicolumn{4}{|c|}{3903,74} & \multicolumn{4}{|c|}{951,46} \\
\hline & \multicolumn{4}{|c|}{$\mathbf{0 , 0 7 7 3}$} & \multicolumn{4}{|c|}{0,0148} \\
\hline Teste F & \multicolumn{4}{|c|}{$F(11,3720)$} & \multicolumn{2}{|c|}{$\mathbf{F}(11,2911)$} & \multicolumn{2}{|c|}{3,97} \\
\hline
\end{tabular}

Tabela II.11. AIH Pagas - Amostra de municípios com população inferior a 50.000 habitantes

\begin{tabular}{|c|c|c|c|c|c|c|c|c|}
\hline \multirow[t]{3}{*}{ V. Dependente } & \multicolumn{8}{|c|}{ AIH Pagas } \\
\hline & \multicolumn{4}{|c|}{ Municípios com hospitais } & \multicolumn{4}{|c|}{ Municípios sem hospitais } \\
\hline & Coef. & Erro Pad & $\mathbf{t}$ & $\mathbf{P}>|\mathbf{t}|$ & Coef. & Erro Pad & $\mathbf{t}$ & $\mathbf{P}>|\mathbf{t}|$ \\
\hline PSF & 443,08 & 158,66 & 2,79 & 0,005 & $-529,06$ & 361,16 & $-1,46$ & 0,143 \\
\hline PACS & 612,20 & 246,97 & 2,48 & 0,013 & $-397,36$ & 715,02 & $-0,56$ & 0,578 \\
\hline PIBPC & $\mathbf{0 , 0 0 1}$ & 0,01 & 0,06 & 0,956 & $-0,004$ & 0,02 & $-0,15$ & $\mathbf{0 , 8 7 9}$ \\
\hline HOSP & 325,26 & 39,00 & 8,34 & 0,000 & 83,74 & 156,71 & 0,53 & 0,593 \\
\hline ODIPC & 9,81 & 1,84 & 5,32 & 0,000 & 3,92 & 4,18 & 0,94 & 0,347 \\
\hline DICEFG & 4,18 & 4,25 & 0,98 & 0,325 & 13,72 & 9,81 & 1,40 & 0,162 \\
\hline DES_EF & $-2,05$ & 4,79 & $-0,43$ & 0,670 & $-51,47$ & 10,05 & $-5,12$ & 0,000 \\
\hline D00 & $-165,20$ & 91,21 & $-1,81$ & 0,070 & 595,90 & 291,35 & 2,05 & 0,041 \\
\hline D01 & $-425,03$ & 109,46 & $-3,88$ & 0,000 & 258,14 & 330,56 & 0,78 & 0,435 \\
\hline D02 & $-643,89$ & 132,18 & $-4,87$ & 0,000 & $-27,29$ & 363,40 & $-0,08$ & 0,940 \\
\hline D03 & $-788,47$ & 129,65 & $-6,08$ & 0,000 & 21,88 & 366,86 & 0,06 & 0,952 \\
\hline CONS & $7.490,43$ & 386,37 & 19,39 & 0,000 & $8.839,75$ & 765,64 & 11,55 & 0,000 \\
\hline Observações & \multicolumn{4}{|c|}{3579} & \multicolumn{4}{|c|}{3618} \\
\hline Hausman - $\chi^{2}(10)$ & \multicolumn{4}{|c|}{66,44} & \multicolumn{4}{|c|}{55,33} \\
\hline Breusch-Pagan - $\chi^{2}(1)$ & \multicolumn{4}{|c|}{2487,19} & \multicolumn{4}{|c|}{938,18} \\
\hline & \multicolumn{4}{|c|}{0,0693} & \multicolumn{4}{|c|}{0,0147} \\
\hline Teste F & $\mathbf{F}(11,2$ & 852) & 19,3 & & $\mathbf{F}(11,2$ & 883) & 3,92 & \\
\hline
\end{tabular}


Tabela II.12. Valor Total do dispêndio para pagamento de AIH

\begin{tabular}{|c|c|c|c|c|c|c|c|c|}
\hline \multirow[t]{3}{*}{$\begin{array}{l}\text { V. Dependente } \\
\end{array}$} & \multicolumn{8}{|c|}{ AIH Pagas } \\
\hline & \multicolumn{4}{|c|}{ Municípios com hospitais } & \multicolumn{4}{|c|}{ Municípios sem hospitais } \\
\hline & Coef. & Erro Pad & $t$ & $\mathbf{P}>|\mathbf{t}|$ & Coef. & Erro Pad & $\mathbf{t}$ & $\mathbf{P}>|\mathbf{t}|$ \\
\hline PSF & 1,85 & 0,87 & 2,14 & 0,033 & $-2,85$ & 1,70 & $-1,68$ & 0,094 \\
\hline PACS & 2,13 & 1,31 & 1,62 & 0,105 & $-1,63$ & 3,37 & $-0,48$ & 0,629 \\
\hline PIBPC & 0,00003 & 0,00004 & 0,59 & 0,558 & 0,00001 & 0,00011 & 0,08 & $\mathbf{0 , 9 4 0}$ \\
\hline HOSP & 0,80 & 0,21 & 3,87 & 0,000 & 0,20 & 0,73 & 0,27 & $\mathbf{0 , 7 8 3}$ \\
\hline ODIPC & 0,07 & 0,01 & 6,35 & 0,000 & 0,024 & 0,020 & 1,21 & $\mathbf{0 , 2 2 8}$ \\
\hline DICEFG & 0,05 & 0,02 & 1,99 & 0,047 & 0,052 & 0,046 & 1,11 & 0,266 \\
\hline DES_EF & $-0,004$ & 0,03 & $-0,17$ & 0,865 & $-0,25$ & 0,05 & $-5,21$ & $\mathbf{0 , 0 0 0}$ \\
\hline D00 & 1,62 & 0,46 & 3,49 & 0,000 & 4,15 & 1,37 & 3,03 & $\mathbf{0 , 0 0 2}$ \\
\hline D01 & 1,91 & 0,56 & 3,43 & 0,001 & 4,38 & 1,55 & 2,82 & 0,005 \\
\hline D02 & 1,93 & 0,70 & 2,76 & 0,006 & 4,73 & 1,71 & 2,77 & 0,006 \\
\hline D03 & 4,66 & 0,69 & 6,77 & 0,000 & 7,71 & 1,73 & 4,46 & 0,000 \\
\hline CONS & 24,75 & 2,11 & 11,70 & 0,000 & 35,99 & 3,61 & 9,97 & $\mathbf{0 , 0 0 0}$ \\
\hline Observações & \multicolumn{4}{|c|}{4664} & \multicolumn{4}{|c|}{3653} \\
\hline Hausman - $\chi^{2}(10)$ & \multicolumn{4}{|c|}{222,42} & \multicolumn{4}{|c|}{79,15} \\
\hline Breusch-Pagan - $\chi^{2}(1)$ & \multicolumn{4}{|c|}{5410,39} & \multicolumn{4}{|c|}{857,39} \\
\hline & \multicolumn{4}{|c|}{0,0605} & \multicolumn{4}{|c|}{0,0166} \\
\hline Teste F & \multicolumn{4}{|c|}{$F(11,3720)$} & \multicolumn{2}{|c|}{$F(11,2911)$} & \multicolumn{2}{|c|}{4,46} \\
\hline
\end{tabular}

Tabela II.13. Valor Total do dispêndio para pagamento de AIH - Amostra de municípios com população inferior a 50.000 habitantes

\begin{tabular}{|c|c|c|c|c|c|c|c|c|}
\hline \multirow[t]{3}{*}{$\begin{array}{l}\text { V. Dependente } \\
\end{array}$} & \multicolumn{8}{|c|}{ AIH Pagas } \\
\hline & \multicolumn{4}{|c|}{ Municípios com hospitais } & \multicolumn{4}{|c|}{ Municípios sem hospitais } \\
\hline & Coef. & Erro Pad & $\mathbf{t}$ & $P>|t|$ & Coef. & Erro Pad & $\mathbf{t}$ & $\mathbf{P}>|\mathbf{t}|$ \\
\hline PSF & 1,45 & 1,03 & 1,40 & 0,161 & $-2,88$ & 1,71 & $-1,68$ & 0,094 \\
\hline PACS & 2,01 & 1,61 & 1,25 & 0,210 & $-1,65$ & 3,39 & $-0,49$ & 0,626 \\
\hline PIBPC & 0,00003 & 0,00006 & 0,52 & 0,606 & 0,00001 & 0,00011 & 0,07 & 0,946 \\
\hline HOSP & 0,81 & 0,25 & 3,20 & 0,001 & 0,18 & 0,74 & 0,24 & 0,811 \\
\hline ODIPC & 0,07 & 0,01 & 5,73 & $\mathbf{0 , 0 0 0}$ & 0,024 & 0,020 & 1,20 & $\mathbf{0 , 2 3 2}$ \\
\hline DICEFG & 0,04 & 0,03 & 1,63 & 0,104 & 0,052 & 0,047 & 1,11 & 0,269 \\
\hline DES_EF & 0,00 & 0,03 & 0,09 & 0,928 & $-0,25$ & 0,05 & $-5,17$ & 0,000 \\
\hline D00 & 1,82 & 0,59 & 3,06 & 0,002 & 4,18 & 1,38 & 3,02 & 0,003 \\
\hline D01 & 2,06 & 0,71 & 2,90 & 0,004 & 4,40 & 1,57 & 2,80 & 0,005 \\
\hline D02 & 2,08 & 0,86 & 2,42 & $\mathbf{0 , 0 1 5}$ & 4,74 & 1,73 & 2,75 & 0,006 \\
\hline D03 & 4,88 & 0,84 & 5,79 & 0,000 & 7,74 & 1,74 & 4,44 & 0,000 \\
\hline CONS & 24,32 & 2,51 & 9,68 & 0,000 & 36,04 & 3,64 & 9,91 & 0,000 \\
\hline Observações & \multicolumn{4}{|c|}{3579} & \multicolumn{4}{|c|}{3618} \\
\hline Hausman - $\chi^{2}(11)$ & \multicolumn{4}{|c|}{221,61} & \multicolumn{4}{|c|}{78,27} \\
\hline Breusch-Pagan - $\chi^{2}(1)$ & \multicolumn{4}{|c|}{$\begin{array}{r}4076,84 \\
00528\end{array}$} & \multicolumn{4}{|c|}{845,73} \\
\hline & \multicolumn{4}{|c|}{0,0528} & \multicolumn{4}{|c|}{0,0166} \\
\hline Teste F & $\mathbf{F}(\mathbf{1 1}$, & 852) & 14,4 & & $\mathbf{F}(11$, & 883) & 4,42 & \\
\hline
\end{tabular}

